\title{
Understanding Nutrients in the Chesapeake Bay Watershed and Implications for Management and Restoration- the Eastern Shore
}

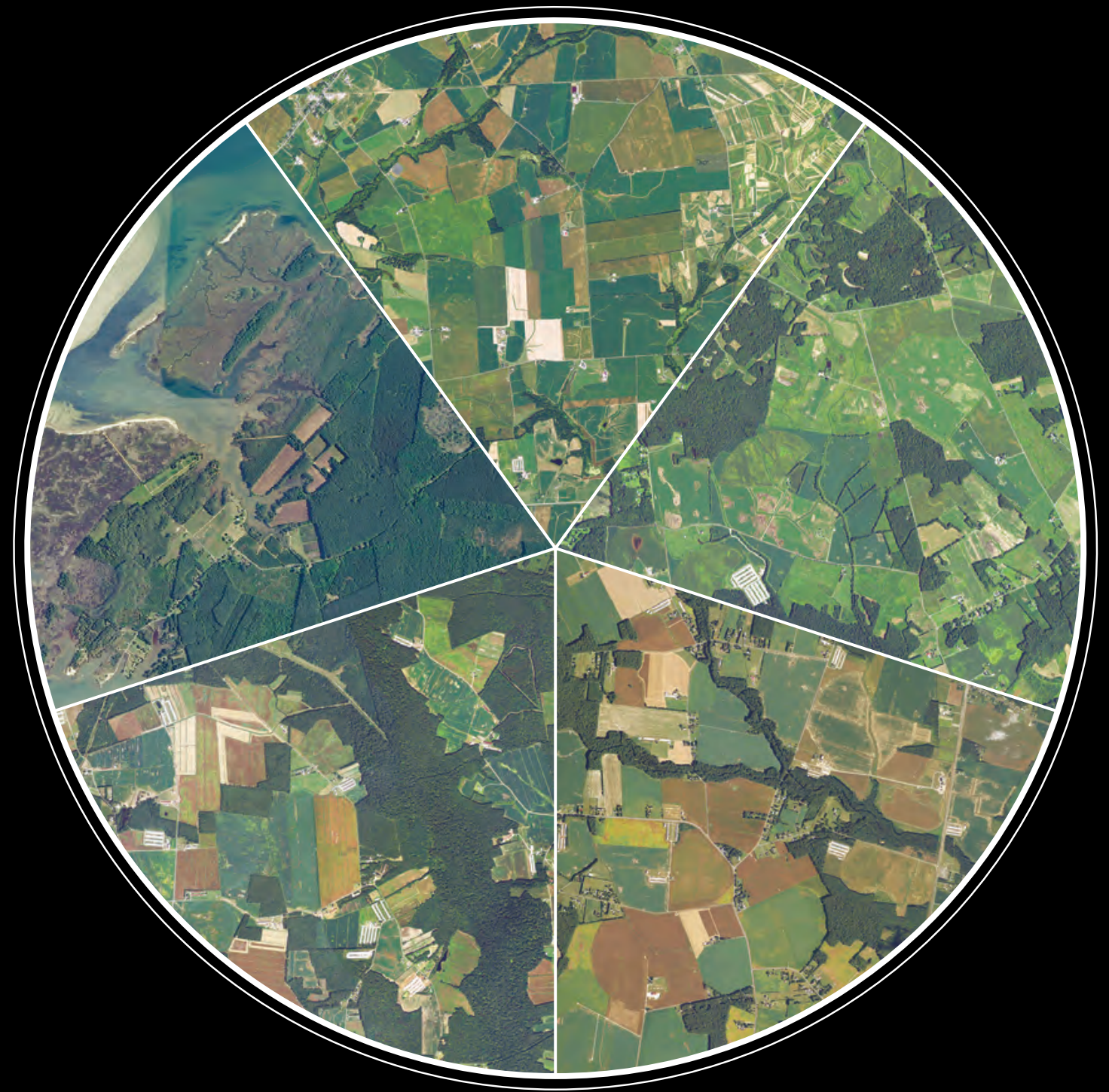

Circular 1406

Version 1.1, May 2015

Version 1.2, June 2015

U.S. Department of the Interior

U.S. Geological Survey 
Cover. Selected landscapes on the Eastern Shore, clockwise from top: Chester River watershed, Choptank River watershed, Nanticoke River watershed, Pocomoke River watershed, and the Eastern Shore of Virginia. Aerial imagery from the National Agricultural Imagery Program, U.S. Department of Agriculture. Refer to figure 40. 


\section{Understanding Nutrients in the Chesapeake Bay Watershed and Implications for Management and Restoration- the Eastern Shore}

By Scott W. Ator and Judith M. Denver

Circular 1406

Version 1.1, May 2015

Version 1.2, June 2015

U.S. Department of the Interior

U.S. Geological Survey 


\title{
U.S. Department of the Interior SALLY JEWELL, Secretary
}

\section{U.S. Geological Survey Suzette M. Kimball, Acting Director}

\author{
U.S. Geological Survey, Reston, Virginia \\ First Release: 2015, online and in print \\ Revised: May 2015 (ver. 1.1), online \\ Revised: June 2015 (ver. 1.2), online
}

\begin{abstract}
For more information on the USGS - the Federal source for science about the Earth, its natural and living resources, natural hazards, and the environment, visit http://www.usgs.gov or call 1-888-ASK-USGS

For an overview of USGS information products, including maps, imagery, and publications, visit http://www.usgs.gov/pubprod

To order this and other USGS information products, visit http://store.usgs.gov
\end{abstract}

Any use of trade, product, or firm names is for descriptive purposes only and does not imply endorsement by the U.S. Government.

Although this report is in the public domain, permission must be secured from the individual copyright owners to reproduce any copyrighted materials contained within this report.

Suggested citation:

Ator, S.W., and Denver, J.M., 2015, Understanding nutrients in the Chesapeake Bay watershed and implications for management and restoration—-the Eastern Shore (ver. 1.2, June 2015): U.S. Geological Survey Circular 1406, 72 p., http://dx.doi.org/10.3133/cir1406. 


\section{Contents}

Chapter 1. Overview of Major Findings ..............................................................................................

The Importance of the Eastern Shore to Chesapeake Bay .................................................................

Sources of Nitrogen and Phosphorus on the Eastern Shore .............................................................

Movement of Nitrogen and Phosphorus From Application Areas on the

Eastern Shore to Chesapeake Bay and Its Tributaries ............................................................5

Nitrogen and Phosphorus in Eastern Shore Groundwater and Surface Waters .............................6

Understanding and Managing Nitrogen and Phosphorus on the Eastern Shore..............................8

Chapter 2. Chesapeake Bay and the Eastern Shore ...........................................................................

Importance of the Eastern Shore to Water Quality in Chesapeake Bay.............................................9

Environmental Setting of the Eastern Shore of Chesapeake Bay...................................................16

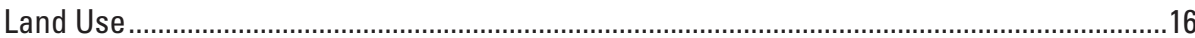

Geology and Soils .............................................................................................................. 18

Climate and Hydrology .......................................................................................................2

Chapter 3. Sources and Movement of Nitrogen and Phosphorus on the Eastern Shore........................27

Sources of Nitrogen and Phosphorus..............................................................................................27

Movement of Nitrogen and Phosphorus from Source Areas to Surface Waters ..........................29

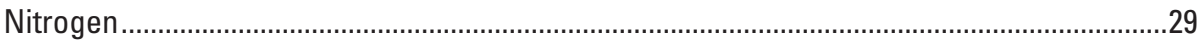

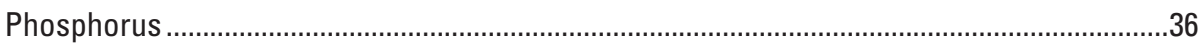

Chapter 4. Nitrogen and Phosphorus in Groundwater and Surface Waters of the Eastern Shore

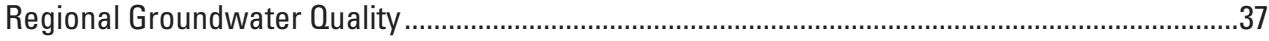

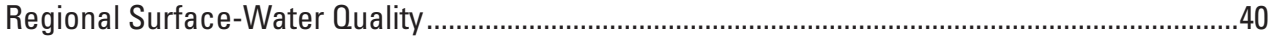

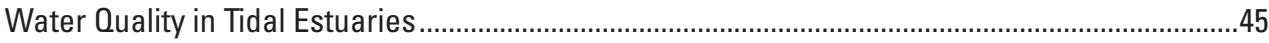

Nitrogen and Phosphorus in Major Eastern Shore Watersheds ..................................................45

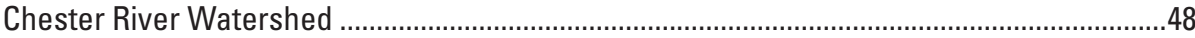

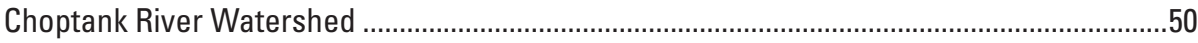

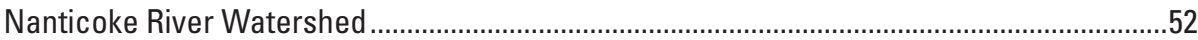

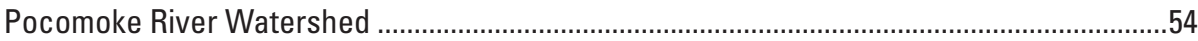

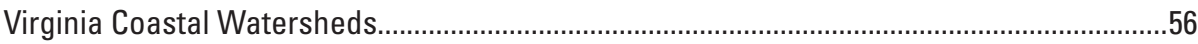

Chapter 5. Understanding Nitrogen in Support of Water Resource Management

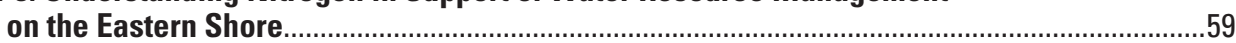

Why are nitrogen concentrations elevated in Eastern Shore groundwater and streams?

Why are nitrogen concentrations in streams and groundwater on the Eastern Shore increasing? ...............................................................................................5

What management practices might be most effective at reducing nitrogen

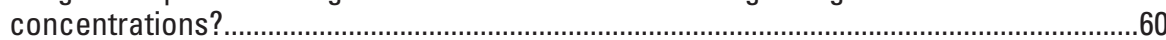

How long will it take to see water-quality improvement and, in the meanwhile, how will we know if land-management or restoration practices are working? ................61

Chapter 6. Understanding Phosphorus in Support of Water Resource Management on the Eastern Shore.

Why are phosphorus concentrations elevated in many agricultural soils on the Eastern Shore? ........................................................................................................ 63

Why is phosphorus moving into streams and groundwater on the Eastern Shore? ......................63

Why is phosphorus continuing to increase in the Choptank River in recent years? ......................64

What management practices may be most effective at limiting phosphorus movement to Eastern Shore streams and groundwater?..................................................64

How long will it take to see water-quality improvement and, in the meanwhile, how will we know if land-management and restoration practices are working? .............64

References Cited 


\section{Figures}

1. Maps showing the Eastern Shore of Chesapeake Bay

2. Graphs showing nitrogen and phosphorus inputs to the Eastern Shore and yields from the Eastern Shore to Chesapeake Bay are substantially greater than in the remainder of the bay watershed.

3. Graph showing nitrogen and phosphorus applications in fertilizer and poultry production increased substantially on the Delmarva Peninsula during the 20th century.

4. Pie charts showing agriculture provides more than 90 percent of the nitrogen and phosphorus inputs to the Eastern Shore.

5. Diagram showing idealized summary of hydrology and nutrient transport on the Eastern Shore in areas with oxic groundwater and well-drained soils

6. Maps showing nitrogen and phosphorus concentrations in Eastern Shore streams commonly exceed concentrations that may adversely affect aquatic ecosystems

7. Graph showing nitrate concentrations have increased in the Choptank River since the 1960s.

8. Graph showing historical loads of dissolved nitrogen from streams on the Eastern Shore to Chesapeake Bay and predicted future loads under four different scenarios of nitrogen inputs to groundwater.

9. Maps showing estimated average annual nitrogen and phosphorus yields to tributaries of Chesapeake Bay.

10. Graph showing estimated average annual yields of nitrogen and phosphorus to Chesapeake Bay from the Eastern Shore and the remainder of the Chesapeake Bay watershed.

11. Graph showing estimated annual inputs of nitrogen and phosphorus to the Eastern Shore and the remainder of the Chesapeake Bay watershed, 2002

12. Map showing the estimated probability of groundwater nitrate concentration exceeding 5 milligrams per liter as $\mathrm{N}$ in the Chesapeake Bay watershed

13. Graphs showing reductions of $(A)$ nitrogen and $(B)$ phosphorus from nonpoint sources in major watersheds of the Eastern Shore required to meet a 2010 Total Maximum Daily Load (TMDL) for the Chesapeake Bay established under the Clean Water Act.

14. Graphs showing annual streamflow and nitrogen and phosphorus loads delivered to Chesapeake Bay, 1990 through 2012

15. Graph showing a summary of selected ecological conditions in Chesapeake

Bay, 1985 through 2012

16. Map showing major land use and land cover on the Eastern Shore, 2001 ....................17

17. Map showing landscape elevations on the Eastern Shore...........................................19

18. Map showing the average texture of surficial sediments on the Eastern Shore ............20

19. Map showing the sand content of Eastern Shore soils ....................................................21

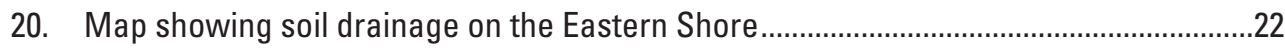

21. Diagram showing conceptual hydrologic cycle and average annual water budget for the Eastern Shore.

22. Map showing variable hydrogeomorphic conditions among different areas of the Eastern Shore

23. Map showing the estimated age of groundwater contributing to streamflow on the Eastern Shore.

24. Pie charts showing annual inputs of nitrogen and phosphorus from various sources to the Eastern Shore 
25. Graph showing past poultry broiler production and fertilizer applications

on the Delmarva Peninsula.

26. Graph showing average annual balance between inputs (primarily in fertilizer and manure) and outputs (primarily in harvested crops) of nitrogen and phosphorus on cropland on the Delmarva Peninsula in recent decades.

27. Diagram showing idealized summary of hydrology and nutrient transport on the Eastern Shore in areas with oxic groundwater and well-drained soils

28. Graph showing the importance of dissolved oxygen concentrations to nitrate concentrations in shallow groundwater on the Delmarva Peninsula, 2001

29. Graph showing the relation of concentrations of nitrate, phosphorus, and suspended sediment to streamflow in Chesterville Branch, 1990-2012

30. Diagrams showing idealized summary of hydrologic conditions and the potential for denitrification in groundwater in various hydrogeologic settings on the Eastern Shore

31. Map showing estimated probability of nitrate concentrations in shallow groundwater exceeding 1 milligram per liter as $\mathrm{N}$ in areas of the Delmarva Peninsula

32. Map showing summary of nitrate concentrations in shallow groundwater in selected agricultural areas of the United States

33. Maps showing summary of nitrogen and phosphorus concentrations in selected streams draining primarily agricultural areas of the United States

34. Graph showing summary of nitrate concentrations in the surficial aquifer on the Delmarva Peninsula during 1988-90 and 2001-03

35. Graphs showing concentrations of nitrogen compounds in streams and shallow groundwater on the Delmarva Peninsula, 2000-01.

36. Maps showing estimated average-annual flow-weighted concentrations of nitrogen and phosphorus in Eastern Shore streams.

37. Graph showing seasonal variability in nitrate concentrations in the Pocomoke River, 1999-2001

38. Map showing ecological conditions in Eastern Shore tributaries to the Chesapeake Bay assessed by sampling communities of benthic aquatic organisms.

39. Graphs showing trends in $(A)$ average nutrient yields during 1985 through 2010 and 2001 through 2010, and $(B)$ nitrate concentrations from the mid-1960s through 2013 in the Choptank River near Greensboro, Maryland

40. Maps showing a summary of selected landscapes on the Eastern Shore

41. Graphs showing estimated nitrogen and phosphorus inputs to the landscape from various sources, 2002, and average annual outputs in streamflow to Chesapeake Bay.

42. Maps showing the Chester River watershed...................................................................49

43. Maps showing the Choptank River watershed...............................................................51

44. Maps showing the Nanticoke River watershed .................................................................53

45. Maps showing the Pocomoke River watershed...............................................................55

46. Maps showing the Virginia Coastal watersheds................................................................57

47. Graph showing changes in nitrate concentrations over time in groundwater beneath adjacent fields after the initiation of winter cover crops in 1988.

48. Graph showing use of cover crops on the Delmarva Peninsula, 1985-2011 ..................62

49. Graph showing forecasted nitrogen delivery from the Eastern Shore to Chesapeake Bay under selected potential management scenarios 


\section{Conversion Factors and Datums}

\begin{tabular}{|c|c|c|}
\hline Multiply & By & To obtain \\
\hline \multicolumn{3}{|c|}{ Length } \\
\hline centimeter $(\mathrm{cm})$ & 0.394 & inch (in.) \\
\hline meter $(\mathrm{m})$ & 3.281 & foot $(\mathrm{ft})$ \\
\hline kilometer $(\mathrm{km})$ & 0.6214 & mile (mi) \\
\hline \multicolumn{3}{|c|}{ Area } \\
\hline square kilometer $\left(\mathrm{km}^{2}\right)$ & 247.1 & acre \\
\hline square kilometer $\left(\mathrm{km}^{2}\right)$ & 0.3861 & square mile $\left(\mathrm{mi}^{2}\right)$ \\
\hline hectare (ha) & 2.471 & acre \\
\hline \multicolumn{3}{|c|}{ Flow rate } \\
\hline meter per day $(\mathrm{m} / \mathrm{d})$ & 3.281 & foot per day (ft/d) \\
\hline \multicolumn{3}{|c|}{ Mass or Yield } \\
\hline kilogram (kg) & 2.205 & pound avoirdupois (lb) \\
\hline megagram $(\mathrm{Mg})$ & 1.102 & ton, short $(2,000 \mathrm{lb})$ \\
\hline megagram (Mg) & 1,000 & kilogram (kg) \\
\hline $\begin{array}{l}\text { kilograms per square kilometer } \\
\left(\mathrm{kg} / \mathrm{km}^{2}\right)\end{array}$ & 0.0089 & pounds per acre (lb/acre) \\
\hline
\end{tabular}

Temperature in degrees Celsius $\left({ }^{\circ} \mathrm{C}\right)$ may be converted to degrees Fahrenheit $\left({ }^{\circ} \mathrm{F}\right)$ as follows:

$$
{ }^{\circ} \mathrm{F}=\left(1.8 \times{ }^{\circ} \mathrm{C}\right)+32
$$

Vertical coordinate information is referenced to the North American Vertical Datum of 1988 (NAVD 88).

Horizontal coordinate information is referenced to the North American Datum of 1983 (NAD 83). Altitude, as used in this report, refers to distance above the vertical datum.

Concentrations of chemical constituents in water are given either in milligrams per liter (mg/L) or micrograms per liter $(\mu \mathrm{g} / \mathrm{L})$. 




\title{
Understanding Nutrients in the Chesapeake Bay Watershed and Implications for Management and Restoration-the Eastern Shore
}

\author{
By Scott W. Ator and Judith M. Denver
}

\section{Chapter 1. Overview of Major Findings}

\section{The Importance of the Eastern Shore to Chesapeake Bay}

\section{SEE CHAPTER 2}

The Eastern Shore (fig. 1) includes only a small part of the Chesapeake Bay watershed, but contributes disproportionately large loads of the excess nitrogen and phosphorus that have contributed to ecological and economic degradation of the bay in recent decades. Chesapeake Bay is the largest

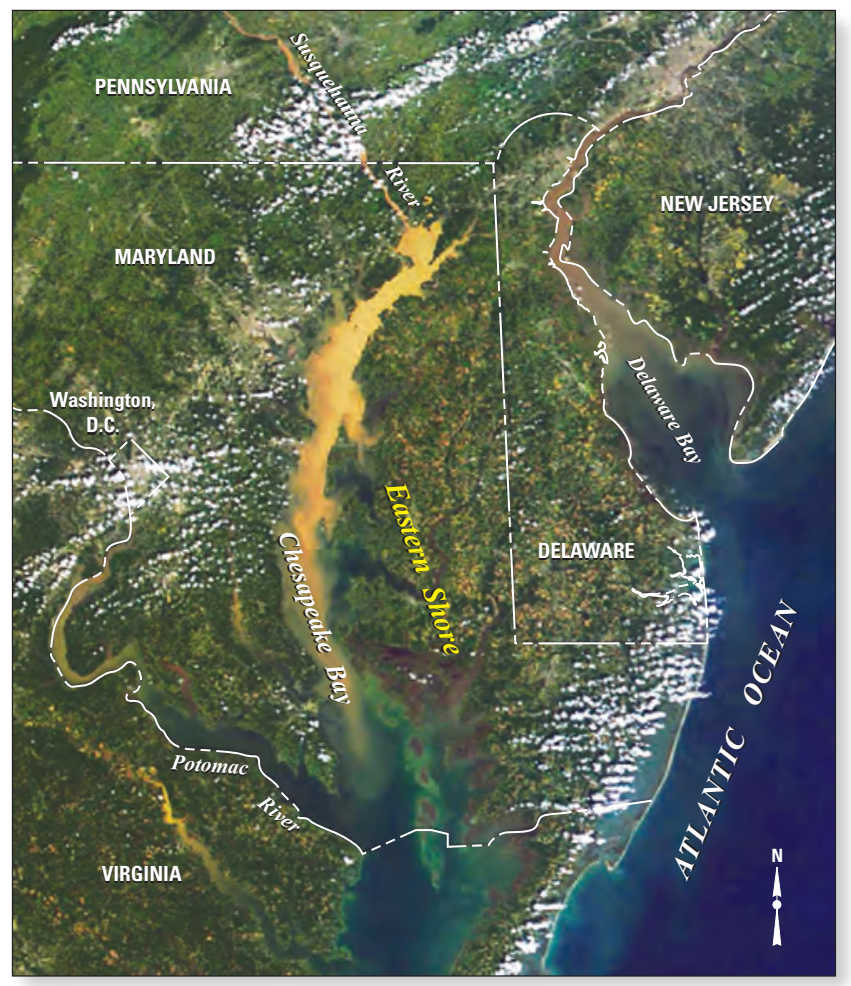

estuary in the United States and a vital ecological and economic resource. The bay and its tributaries have been degraded in recent decades by excessive nitrogen and phosphorus in the water column, however, which cause harmful algal blooms and decreased water clarity, submerged aquatic vegetation, and dissolved oxygen. The disproportionately large nitrogen and phosphorus yields from the Eastern Shore to Chesapeake Bay are attributable to human land-use practices as well as natural hydrogeologic and soil conditions. Applications of nitrogen and phosphorus compounds to the Eastern Shore from human activities are intensive. Also, hydrogeologic and soil conditions promote the movement of these compounds from application areas on the landscape to groundwater and (or) surface waters, and the proximity of much of the Eastern Shore to tidal waters limits opportunities for natural removal of these compounds in the landscape. The Eastern Shore only includes 7 percent of the Chesapeake Bay watershed, but receives nearly twice as much nitrogen and phosphorus applications (per area) as the remainder of the watershed and yields greater nitrogen and phosphorus, on average, to the bay (fig. 2).

Aerial view of Maryland's Eastern Shore modified from the National Aeronautics and Space Administration (NASA) Terra satellite MODIS (Moderate Resolution Imaging Spectroradiometer) image of September 13, 2011. 


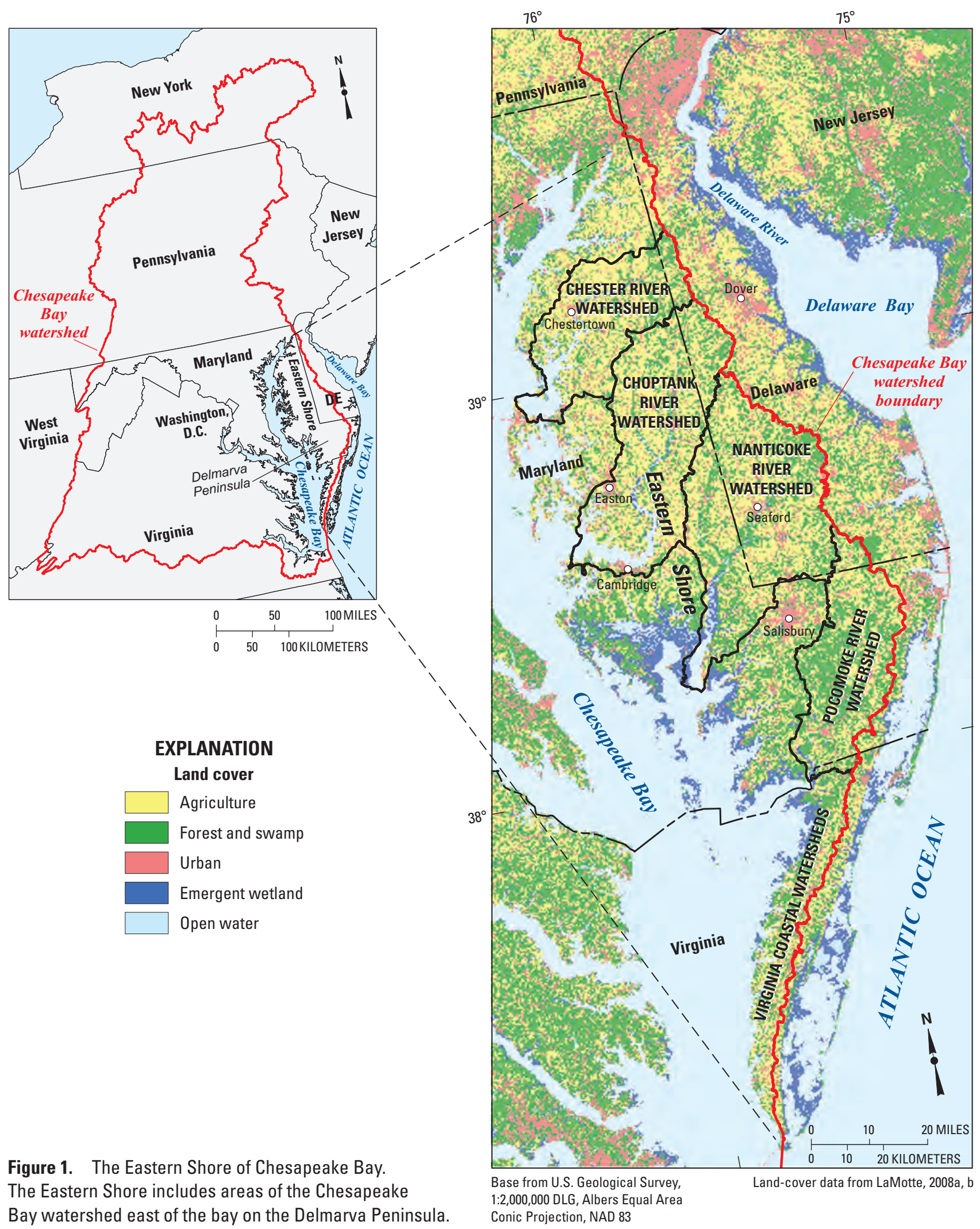



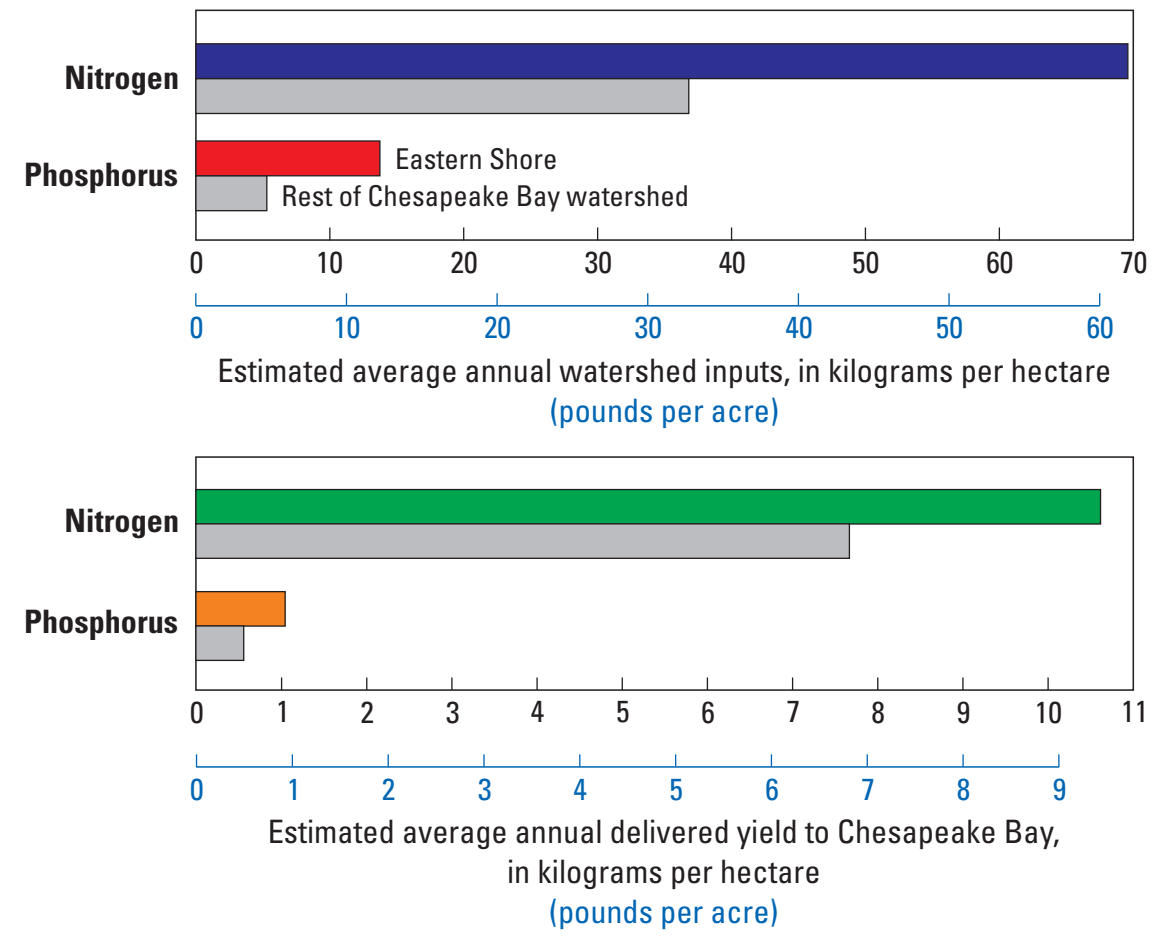

[Estimated inputs from Bachman and others, 1998, Wieczorek and LaMotte, 2010a, b, c, d, and Ator and others, 2011. Estimated yields from Ator and others, 2011.]

Figure 2. Nitrogen and phosphorus inputs to the Eastern Shore and yields from the Eastern Shore to Chesapeake Bay are substantially greater than in the remainder of the bay watershed. 


\section{Sources of Nitrogen and Phosphorus on the Eastern Shore}

\section{SEE CHAPTER 3}

Agricultural operations contribute the vast majority of nitrogen and phosphorus to the landscape on the Eastern Shore. Land use in the area has been primarily agricultural for

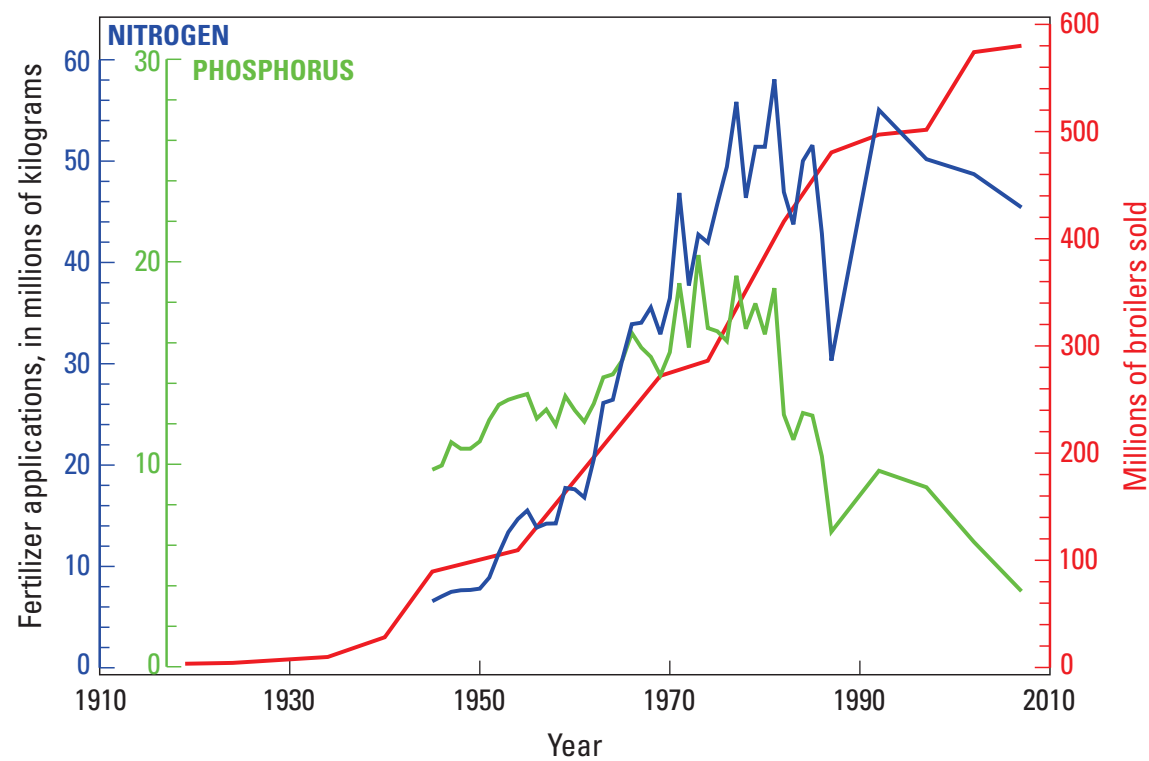

[Broiler data are from U.S. Department of Agriculture, 2009. Estimates prior to 1950 are for total chickens or broilers raised. Fertilizer inputs are from Alexander and Smith, 1990, Battaglin and Goolsby, 1995, and Mid-Atlantic Water Program, 2012.] several hundred years. Nitrogen and phosphorus applications in support of agriculture increased substantially during the second half of the last century, however, but have since stabilized or decreased (fig. 3). More than 90 percent of nitrogen and phosphorus reaching the land in the Eastern Shore is applied as part of inorganic fertilizers or manure, or (for nitrogen) fixed directly from the atmosphere in cropland (fig. 4). Nonagricultural sources such as atmospheric deposition, septic systems, sewage treatment plants, or other urban sources are locally important in some areas, but provide less than 10 percent of nitrogen and phosphorus applications to the Eastern Shore, as a whole. Nitrogen and phosphorus applications to cropland on the Eastern Shore generally exceed the amount that is removed in crops during harvest, and agricultural applications therefore represent a net additional input of these compounds to the environment each year.

Figure 3. Nitrogen and phosphorus applications in fertilizer and poultry production increased substantially on the Delmarva Peninsula during the 20th century.

\section{INPUTS TO THE EASTERN SHORE}

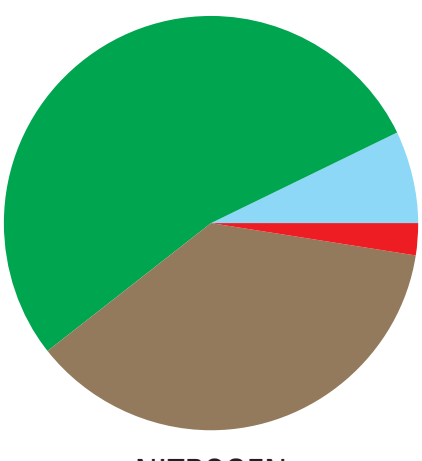

NITROGEN

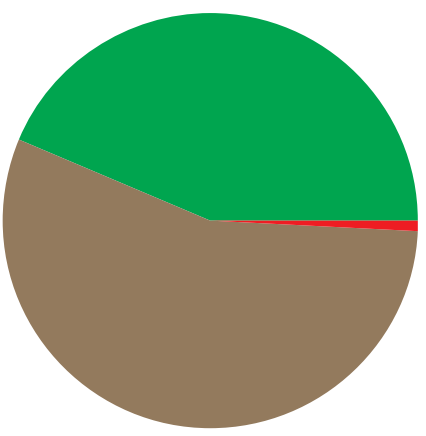

PHOSPHORUS

\section{SOURCE}

Fertilizer applications or (for nitrogen) direct fixation from the atmosphere by crops (Wieczorek and LaMotte, 2010b).

Manure (Wieczorek and LaMotte, 2010c).

Atmospheric deposition (Wieczorek and LaMotte, 2010d).

Other, including point sources (U.S. Environmental Protection Agency, 2009) and septic systems (Maizel and others, 1997).

Figure 4. Agriculture provides more than 90 percent of the nitrogen and phosphorus inputs to the Eastern Shore. 


\section{Movement of Nitrogen and Phosphorus From Application Areas on the Eastern Shore to Chesapeake Bay and Its Tributaries}

\section{SEE CHAPTER 3}

Once on the land surface, nitrogen and phosphorus movement to surface waters occurs primarily through the action of water. Nitrogen is primarily transported to surface waters through groundwater in the form of nitrate (fig. 5). Nitrate may be lost from the landscape to the atmosphere in groundwater with limited dissolved oxygen, but natural hydrogeologic and soil conditions conducive to plentiful dissolved oxygen in groundwater are common in many areas of the Eastern Shore, and 70 percent of nitrogen in Eastern Shore streams travels to those streams through groundwater as nitrate. Phosphorus, conversely, is predominantly transported over the land in runoff attached to sediment (fig. 5). The pathways and amounts of these chemicals entering surface waters are controlled by the amounts that have been applied in excess of crop uptake, differing chemical and physical properties of nitrogen and phosphorus compounds, and by varying hydrologic, geochemical, and geologic environments in different areas.

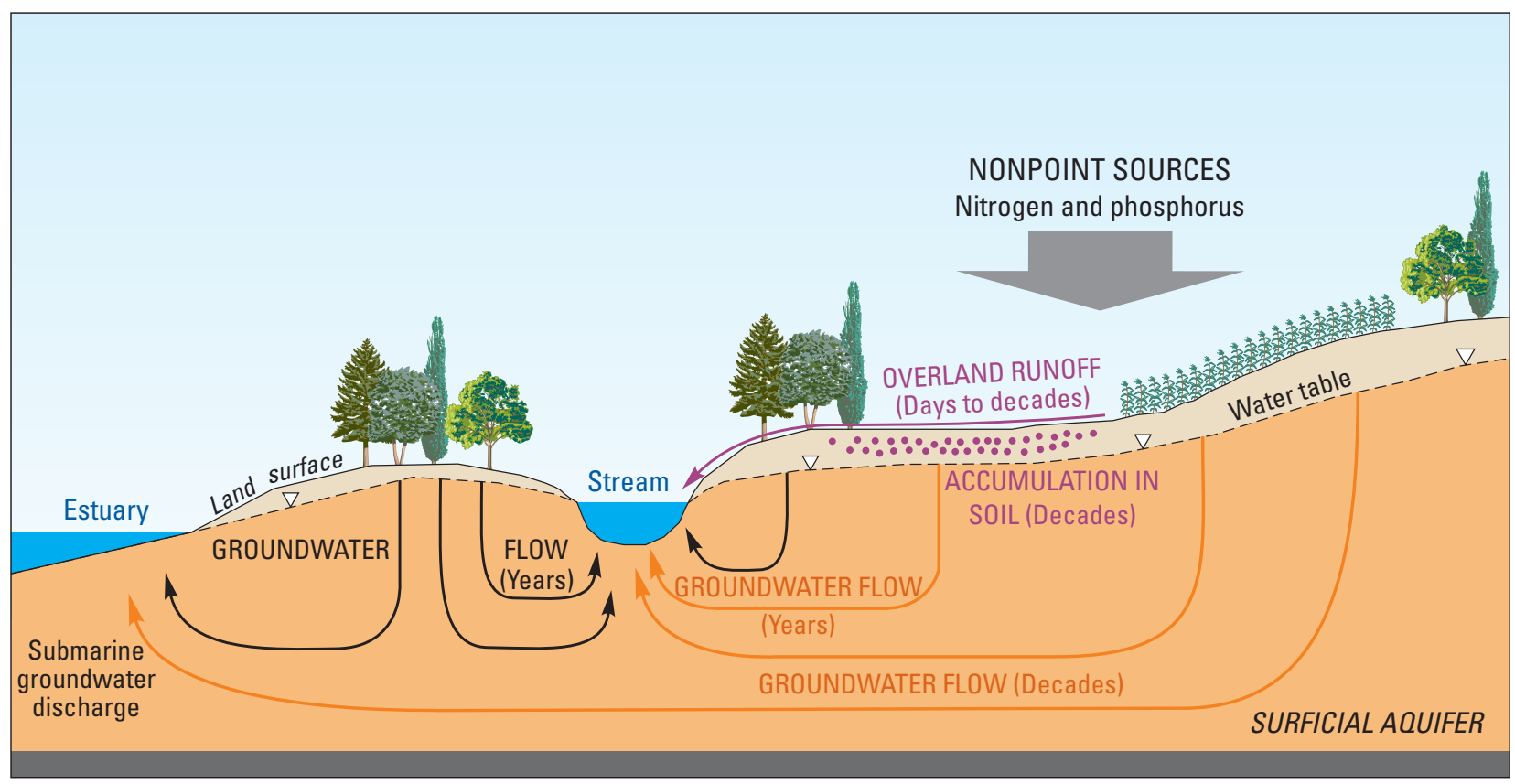

\section{EXPLANATION}

Hydrogeologic units

Unsaturated zone above the water table
Aquifer with oxic groundwater

Confining unit

\section{Flow path or storage location} $\longrightarrow$ Flow path with natural water chemistry an

$\longrightarrow$ Flow path with nitrate and any dissolved phosphorus

\footnotetext{
$\longrightarrow$ Flow path with insoluble phosphorus and nitrogen compounds (such as organic nitrogen)

$\therefore \quad$ Storage of insoluble phosphorus
}

Figure 5. Idealized summary of hydrology and nutrient transport on the Eastern Shore in areas with oxic groundwater and well-drained soils. Nitrogen transport from the land surface to streams occurs primarily through groundwater in the form of nitrate, whereas phosphorus transport occurs primarily in overland runoff. 


\section{Nitrogen and Phosphorus in Eastern Shore Groundwater and Surface Waters}

\author{
SEE CHAPTER 4
}

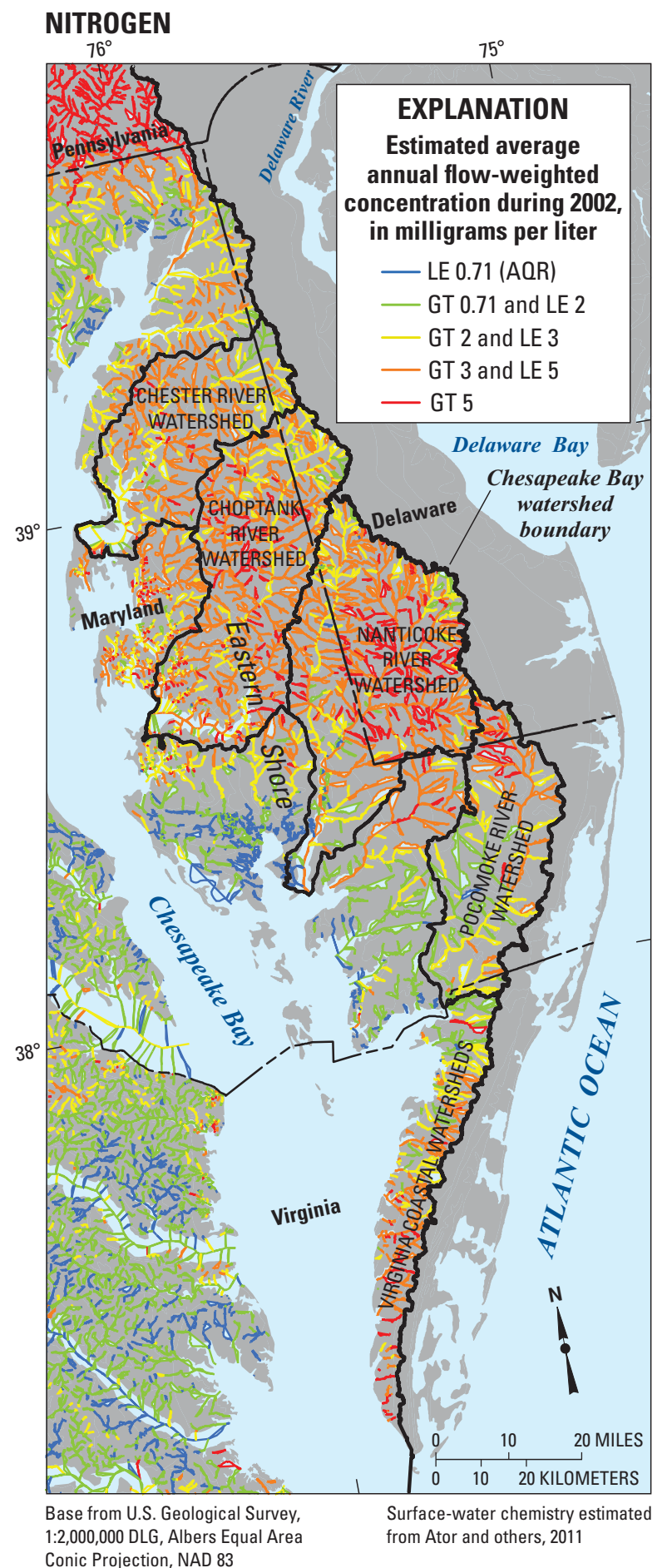

On the Eastern Shore, nitrogen is common in groundwater and surface waters and phosphorus is common in surface waters at concentrations that are well above natural levels, and are among the highest in the Nation. Nitrogen and phosphorus commonly occur in streams at concentrations that may adversely affect aquatic ecosystems (fig. 6) and have increased

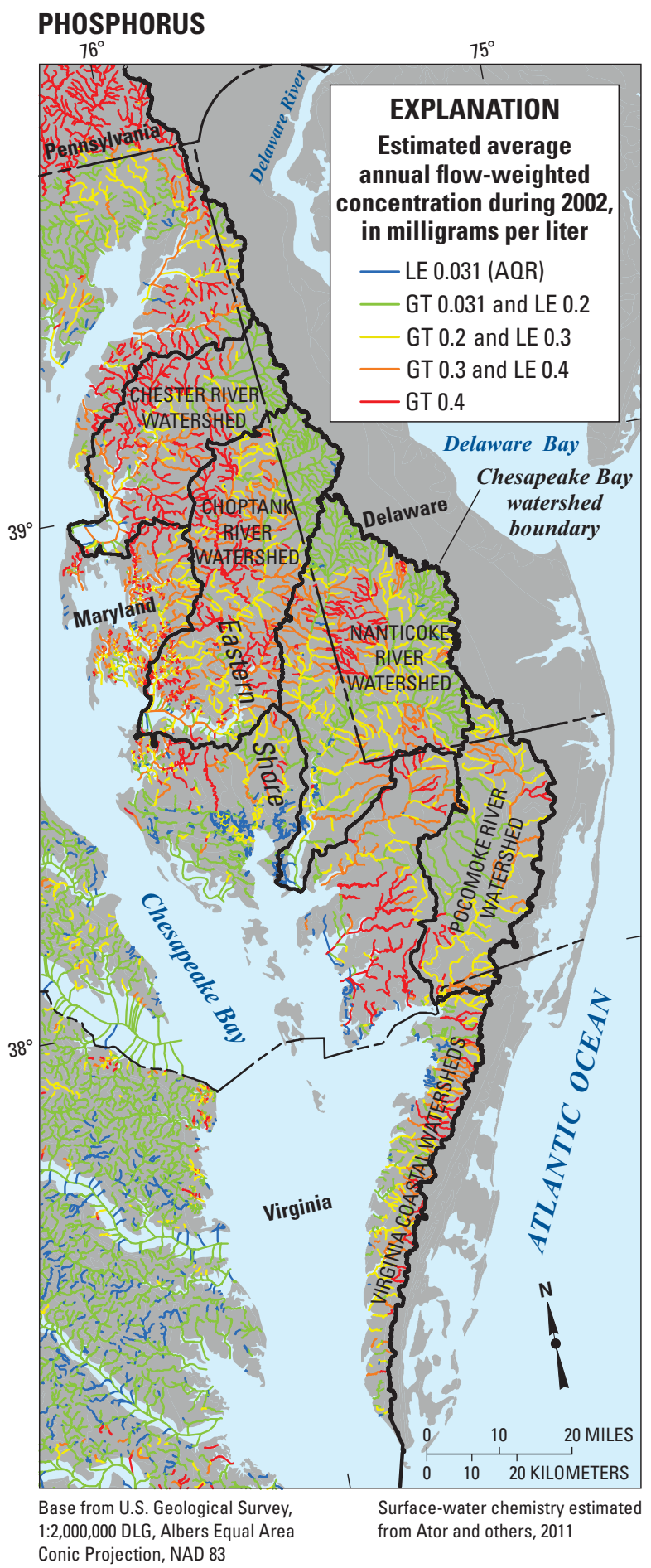

Figure 6. Nitrogen and phosphorus concentrations in Eastern Shore streams commonly exceed concentrations that may adversely affect aquatic ecosystems. ( $A Q R$ is the water-quality criteria recommended to protect aquatic organisms [U.S. Environmental Protection Agency, 2000]. GT = greater than; $\mathrm{LE}=$ less than or equal to.) 
in recent decades (fig. 7). Nitrate concentrations in the Choptank and Nanticoke Rivers have increased consistently since the mid-1960s (fig. 7), primarily due to increasing nitrate concentrations in groundwater discharge, the primary source of both water and nitrogen to those rivers. Nitrate concentrations in groundwater in the shallow surficial aquifer increased in parts of the aquifer between 1988 and 2001 in response to increased nitrogen applications in previous decades, and concentrations that may affect the suitability of the water for drinking are not uncommon. Differing nutrient concentrations in different areas are attributable to varying inputs from agriculture and other sources, as well as hydrogeologic, soil, and other natural conditions that affect the fate and movement of nitrogen compounds through the subsurface and phosphorus over the land surface.

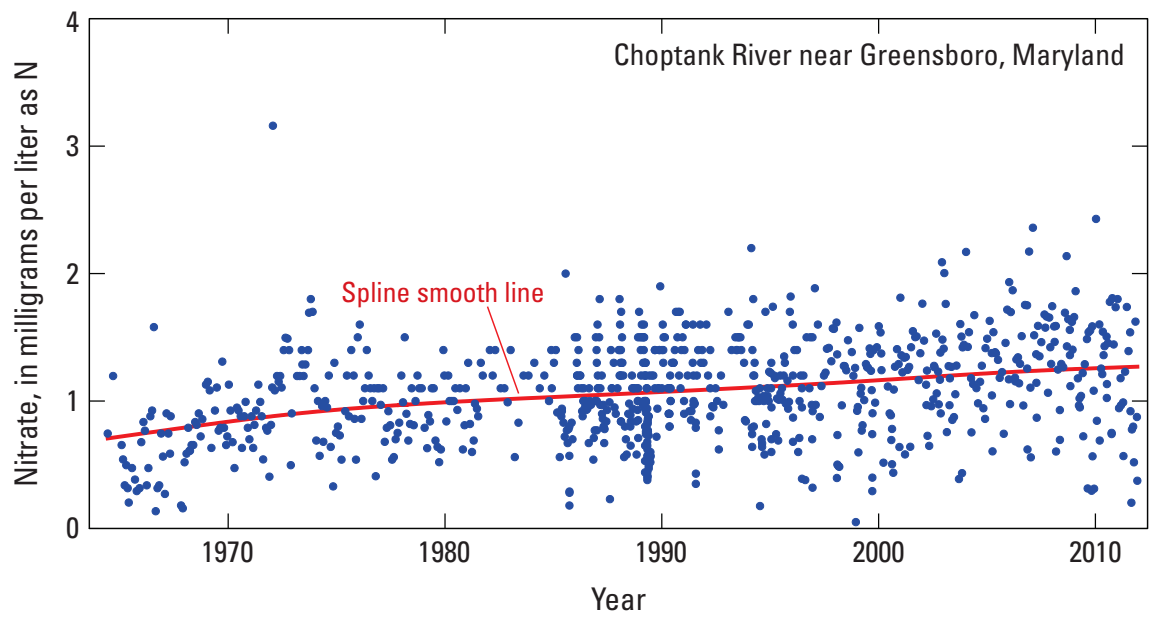

[From U.S. Geological Survey, 2014. See also Moyer and others, 2012.]

Figure 7. Nitrate concentrations have increased in the Choptank River since the 1960s.

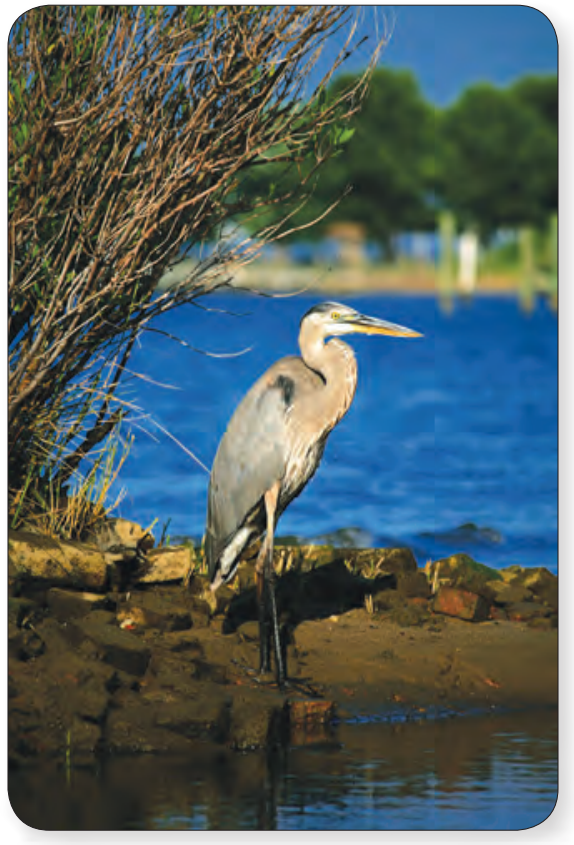

Great blue heron on the shores of the Choptank River. Photograph by Jane Thomas, Integration and Application Network, University of Maryland Center for Environmental Science (ian.umces.edu/imagelibrary/).

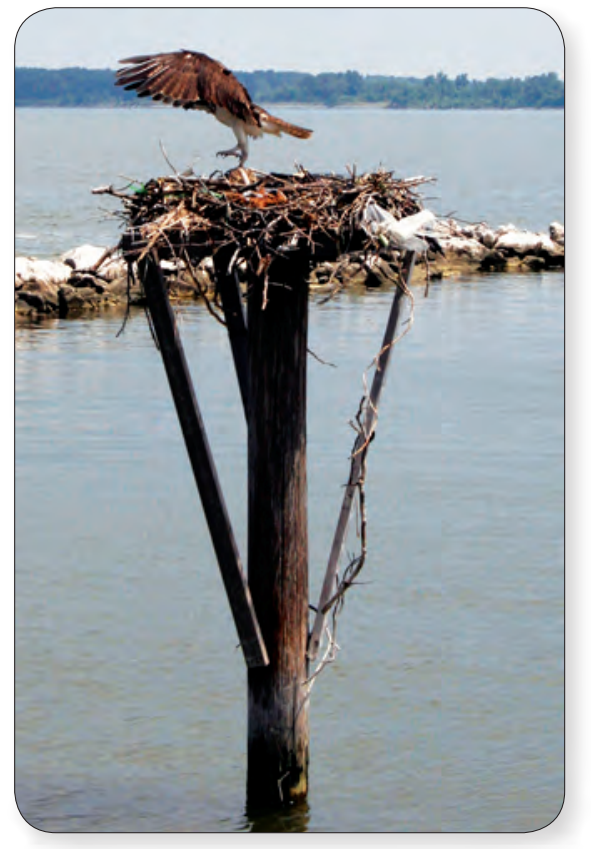

Osprey nesting in the Choptank River. Photograph by Ben Fertig, Integration and Application Network, University of Maryland Center for Environmental Science (ian.umces.edu/imagelibrary/). 


\section{Understanding and Managing Nitrogen and Phosphorus on the Eastern Shore}

\section{SEE CHAPTERS 5 AND 6}

Natural hydrogeologic and geochemical conditions promote the formation and movement of nitrate from the abundant (primarily agricultural) nitrogen sources on the Eastern Shore to groundwater, streams, and estuaries. Increasing nitrate concentrations over time largely reflect the increasing nitrogen applications in previous decades and the typically long time periods required for the movement of nitrate along groundwater flow paths to surface waters. Limiting the movement of nitrate to the water table could reduce concentrations relatively quickly in shallow groundwater, although many years or decades would be required before significant reductions occurred in deeper groundwater or receiving surface waters (fig. 8).

Applications of phosphorus to Eastern Shore farmland in recent decades have far exceeded the amounts necessary for crop growth, and consequently, phosphorus has increased in the environment. Unlike nitrate, phosphorus is relatively insoluble in water under most natural conditions, and excess phosphorus in the environment generally accumulates in agricultural soils rather than moving into groundwater. Reducing the accumulated phosphorus in Eastern Shore soils may be effective at limiting concentrations in streams and groundwater.

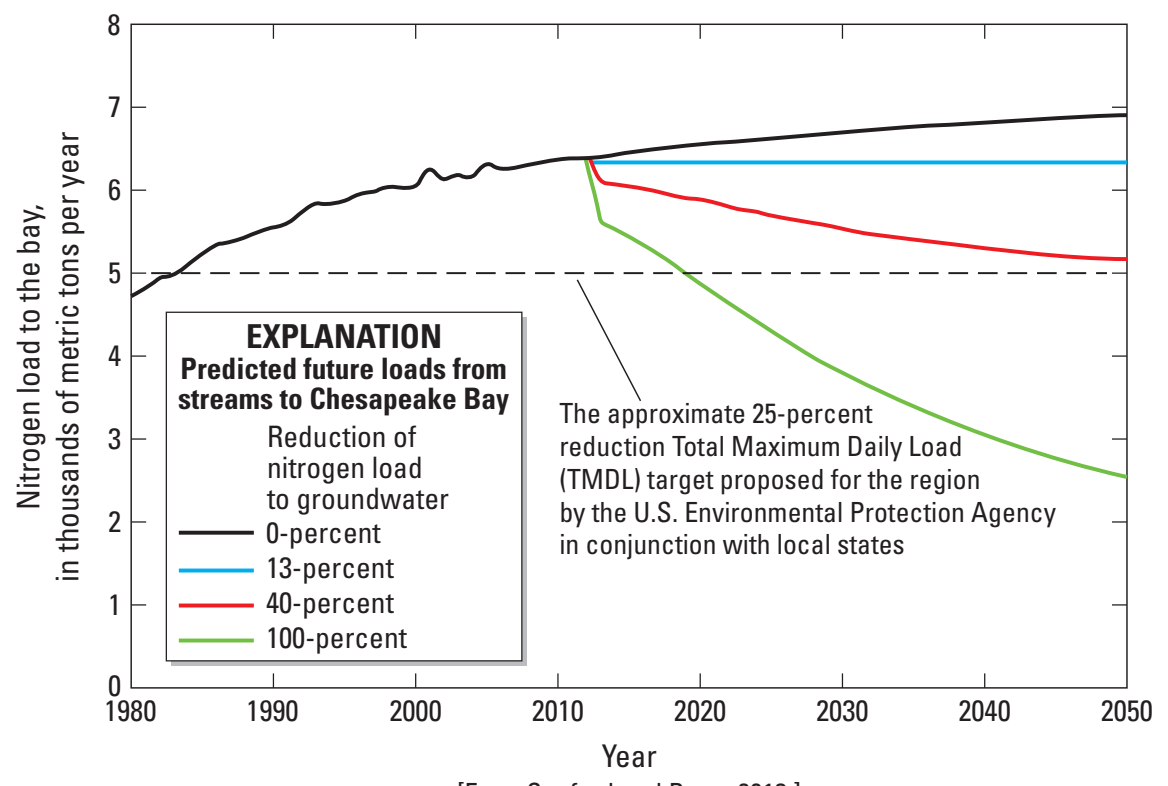

[From Sanford and Pope, 2013.]

Figure 8. Historical loads of dissolved nitrogen from streams on the Eastern Shore to Chesapeake Bay and predicted future loads under four different scenarios of nitrogen inputs to groundwater. Because groundwater flow is generally very slow, the effects of reductions in nitrate concentrations reaching groundwater will not be fully realized in surface waters for many years. Even maintaining dissolved nitrogen loads from streams on the Eastern Shore to the bay at 2012 levels will require a 13-percent reduction in nitrogen loads to groundwater. 


\section{Chapter 2. Chesapeake Bay and the Eastern Shore}

\author{
Why is the Eastern Shore important to water quality in \\ Chesapeake Bay? What are the ecological and management \\ challenges facing Chesapeake Bay, and what are the envi- \\ ronmental conditions in the Eastern Shore that contribute to \\ these challenges?
}

The Eastern Shore includes only 7 percent of the Chesapeake Bay watershed, but contributes disproportionately large loads of the excess nitrogen and phosphorus that have contributed to ecological and economic degradation of the bay in recent decades. Sources of nitrogen and phosphorus compounds are abundant on the Eastern Shore, and hydrogeologic and soil conditions promote the movement from application areas on the landscape of nitrogen to groundwater and streams and phosphorus to streams that contribute to nearby tidal waters.

\section{Importance of the Eastern Shore to Water Quality in Chesapeake Bay}

Chesapeake Bay is the largest estuary in the United States and an important natural resource. As in many inland estuaries along the east coast of North America, however, excessive nitrogen and phosphorus in bay waters have contributed to ecological and economic degradation in recent decades (Kemp and others, 2005; Bricker and others, 2007; U.S. Environmental Protection Agency, 2011a) (see sidebar: "Water-Quality and Restoration Challenges in Chesapeake Bay"). The Eastern Shore, which includes the area of the Chesapeake Bay watershed east of the bay on the Delmarva Peninsula (fig. 1), is a relatively small part of the bay

\section{What are Stream Loads and Yields?}

Chemical transport by streams and rivers is often measured and reported in terms of loads or yields. A stream load is the total rate of transport of a particular chemical, or the amount of chemical transported past a particular point during a specified period of time. Stream loads are often reported in units of mass per time, such as kilograms per year (kg/yr). Stream loads are generally proportional to watershed area; streams draining larger watersheds generally carry greater loads than those draining smaller watersheds. To compare chemicals contributed by different landscapes to streams of different sizes, therefore, stream yield is often useful. Yield is computed as the load per watershed area, and is reported in units of mass per time per area, such as kilograms per year per square kilometer [( $\left.\mathrm{kg} / \mathrm{yr}) / \mathrm{km}^{2}\right]$. watershed, but contributes disproportionately large loads and yields of ecologically harmful excess nutrients (nitrogen and phosphorus) to the bay (see sidebar: "What are Stream Loads and Yields?") (figs. 9, 10).

The importance of the Eastern Shore to water quality in Chesapeake Bay is a result of a combination of natural conditions and human influences. Sources of nitrogen and phosphorus to the land surface, primarily from agricultural fertilizer and manure applications, are abundant on the Eastern Shore (fig. 11). Although the Eastern Shore includes only 7 percent of the land area in the bay watershed, it receives more than 13 percent of the nitrogen and phosphorus applications in the form of fertilizer, manure, and (for nitrogen) direct fixation of atmospheric nitrogen by legume crops (Wieczorek and LaMotte, 2010b, c). Soils and surficial aquifer sediments are sandy and permeable over much of the area-conditions that promote the movement of nutrients from application areas to groundwater, streams, and tidal waters (Böhlke and Denver, 1995; Denver and others, 2004; Ator, Denver, and Brayton, 2005; Debrewer and others, 2007). In addition, the proximity of most areas of the Eastern Shore to tidal waters limits the opportunities for natural storage and mitigation of landapplied nutrients in upland landscapes and increases the likelihood of their delivery to the bay (Staver and Brinsfield, 2001).

Abundant sources of nitrogen and phosphorus and natural conditions on the Eastern Shore contribute to concentrations of nitrate in groundwater (fig. 12) and yields of nitrogen and phosphorus in streams (figs. 9, 10) that are among the highest in the bay watershed. More than 10 percent of nonpoint nitrogen applications to the Eastern Shore move through groundwater to streams as nitrate, and groundwater contributes more nitrate to streams on the Eastern Shore than to streams in the entire remainder of the Atlantic Coastal Plain, from North Carolina through New Jersey, combined (Ator and Denver, 2012). Phosphorus transport from the land surface to streams also is more efficient in the Eastern Shore than in most other areas of the Chesapeake Bay watershed, possibly due to concentrated phosphorus in cropland soils related to excessive historical applications (Ator and others, 2011). Nearly a quarter and a third of phosphorus loads to the bay attributable to manure and fertilizer applications (respectively) are contributed from the Eastern Shore (Ator and others, 2011). Substantial nitrogen and phosphorus load reductions from the Eastern Shore will be required to meet water-quality standards designed to restore the bay (fig. 13) (see sidebar: "WaterQuality and Restoration Challenges in Chesapeake Bay") (figs. 14, 15).

Sources of nitrogen and phosphorus are abundant on the Eastern Shore, and natural conditions promote the movement of these contaminants to groundwater and streams in many areas.

Consequently, levels of nitrate in groundwater and nitrogen and phosphorus in streams on the Eastern Shore are among the highest in the Chesapeake Bay watershed. 


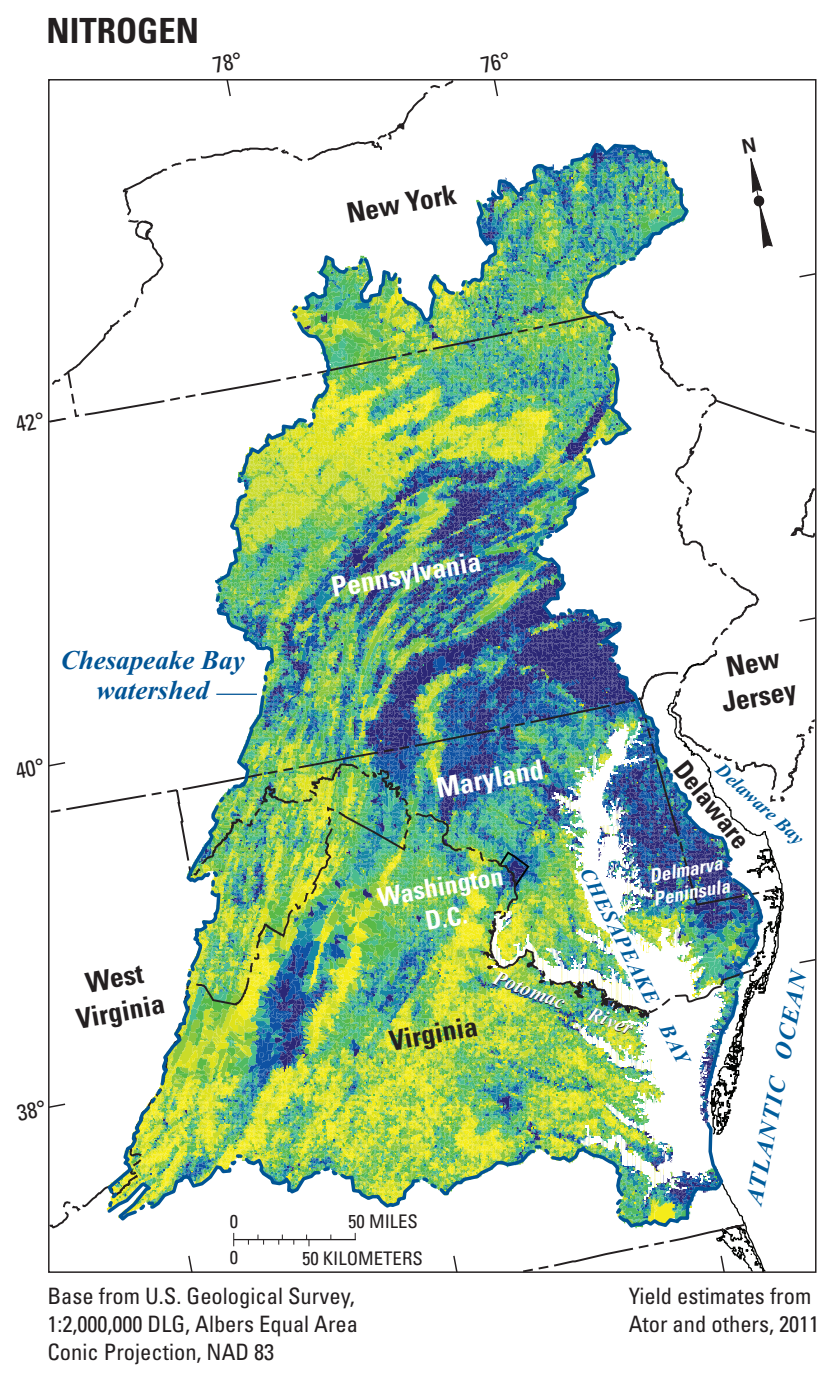

EXPLANATION

Estimated annual yield of nitrogen to local streams, in kilograms per hectare (pounds per acre)

LE 2 (1.8)

GT 2 and LE $4(3.6)$

GT 4 and LE 8 (7.1)

GT 8 and LE 12 (10.7)

GT 12

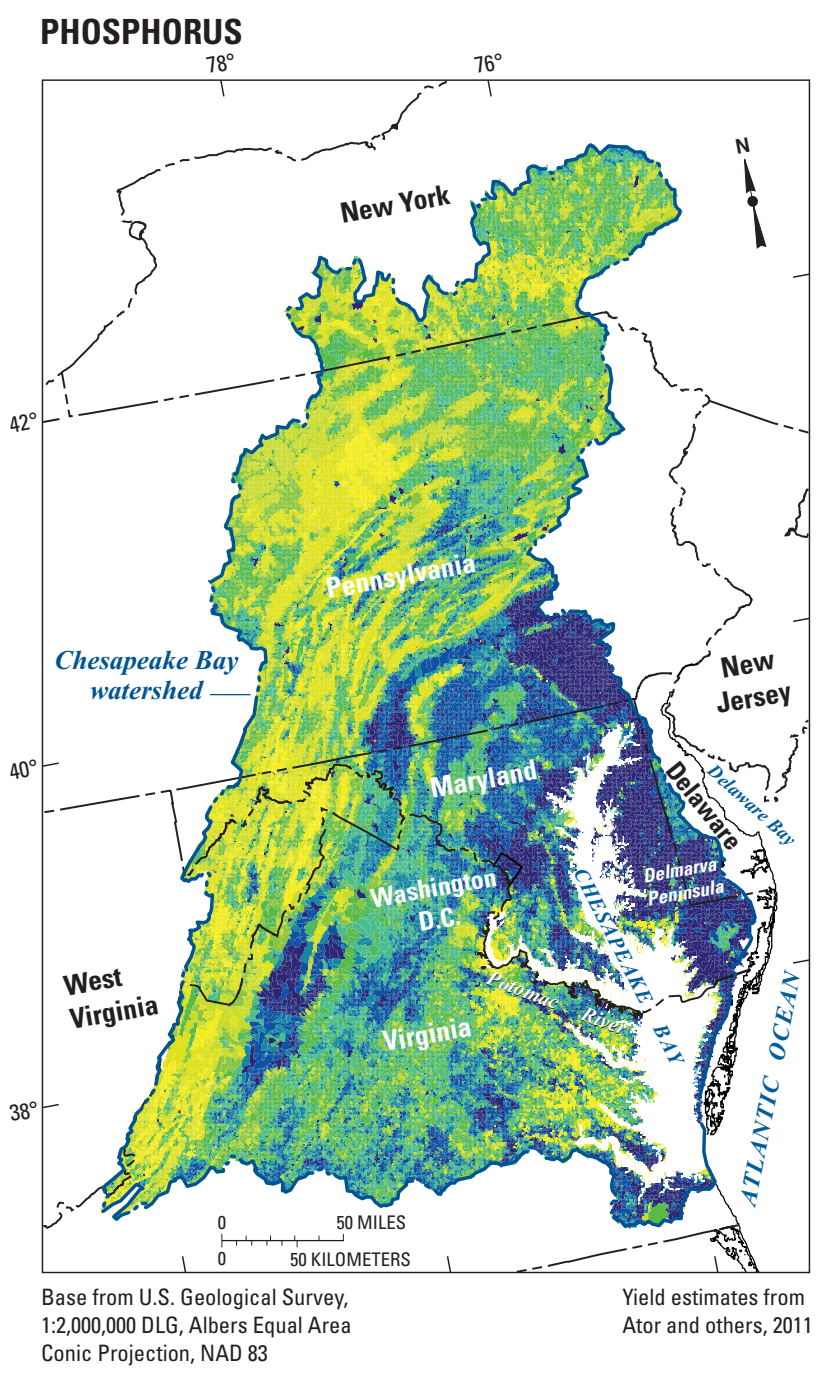

EXPLANATION

Estimated annual yield of phosphorus to local streams, in kilograms per hectare (pounds per acre)

LE 0.10 (0.09)

GT 0.1 and LE $0.15(0.13)$

GT 0.15 and LE $0.25(0.22)$

GT 0.25 and LE $0.50(0.44)$

GT 0.50

Figure 9. Estimated average annual nitrogen and phosphorus yields to tributaries of Chesapeake Bay. Yields to Eastern Shore streams are among the highest in the bay watershed. (GT = greater than; $\mathrm{LE}=$ less than or equal to.) 


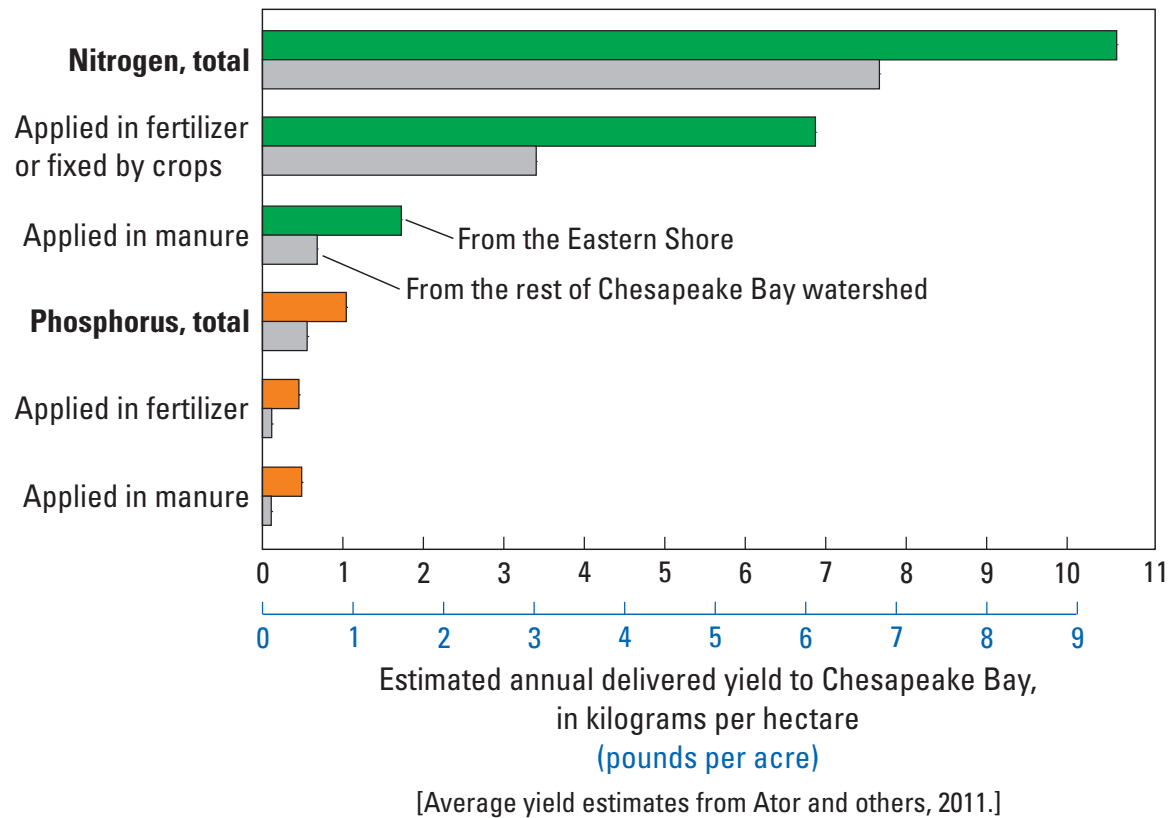

Figure 10. Estimated average annual yields of nitrogen and phosphorus to Chesapeake Bay from the Eastern Shore and the remainder of the Chesapeake Bay watershed. Yields from the Eastern Shore are substantially larger than from the remainder of the watershed.

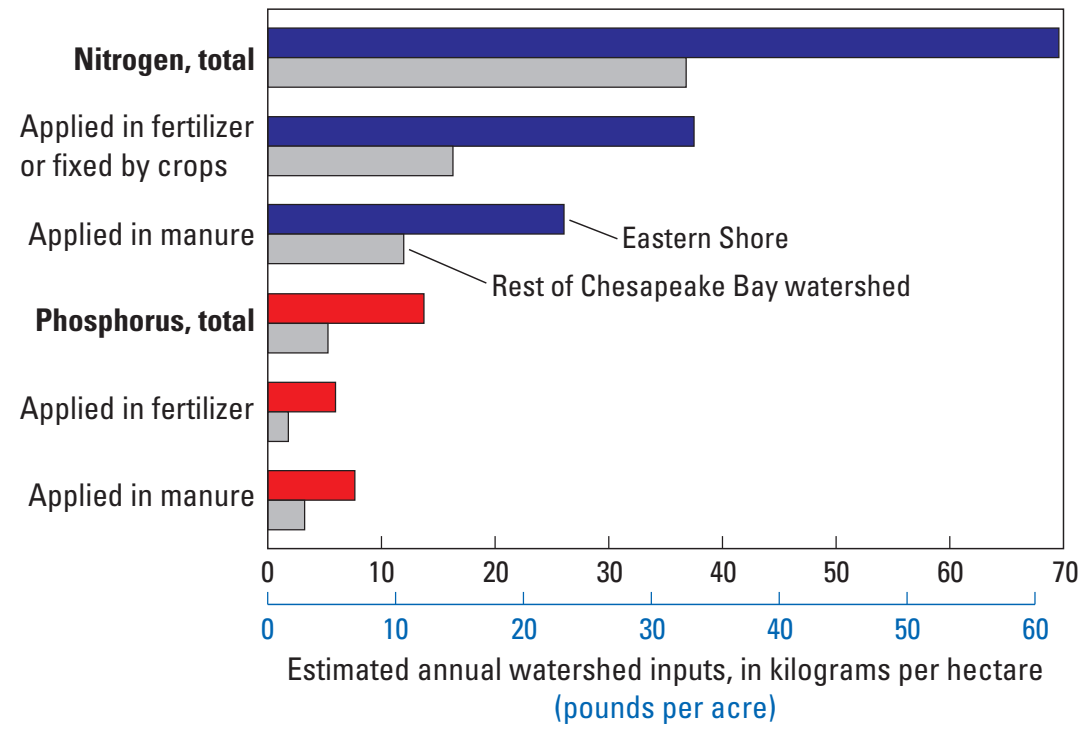

[Average inputs from Bachman and others, 1998, Wieczorek and LaMotte, 2010a, b, c, d, and Ator and others, 2011.]

Figure 11. Estimated annual inputs of nitrogen and phosphorus to the Eastern Shore and the remainder of the Chesapeake Bay watershed, 2002. Inputs are more intensive (greater per unit area) on the Eastern Shore than in the remainder of the Chesapeake Bay watershed. 
EXPLANATION

Likelihood (in percent) of nitrate concentration exceeding 5 milligrams per liter as $\mathbf{N}$ in shallow groundwater

LE 10

GT 10 and LE 20

GT 20 and LE 30

GT 30 and LE 40

GT 40 and LE 50

GT 50 and LE 60

GT 60 and LE 70

GT 70 and LE 80

GT 80 and LE 90

GT 90 and LE 100

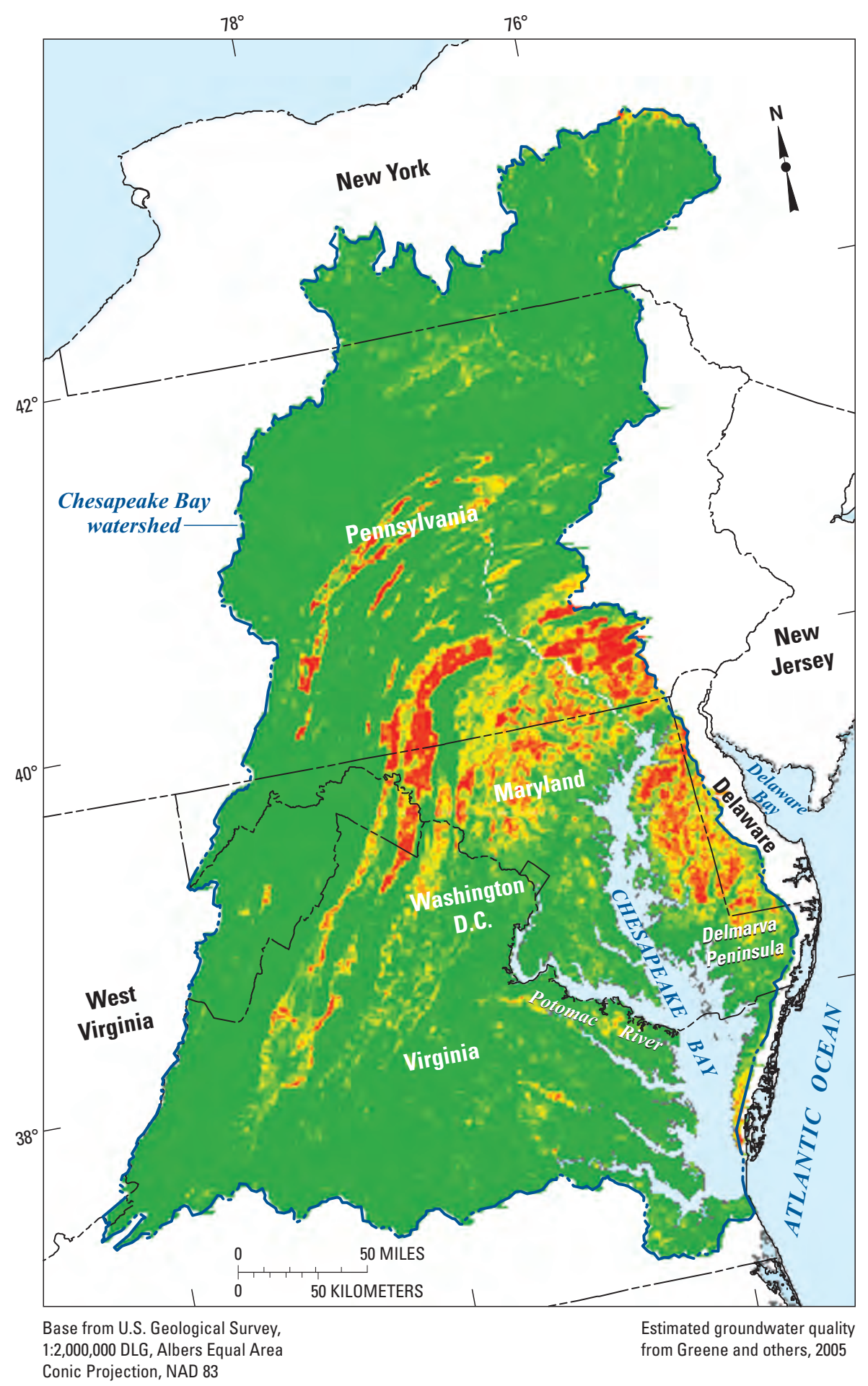

Figure 12. The estimated probability of groundwater nitrate concentration exceeding 5 milligrams per liter as $\mathrm{N}$ in the Chesapeake Bay watershed. Some of the highest concentrations of nitrate in groundwater in the watershed occur in agricultural areas of the Eastern Shore. (GT = greater than; $\mathrm{LE}=$ less than or equal to.) 

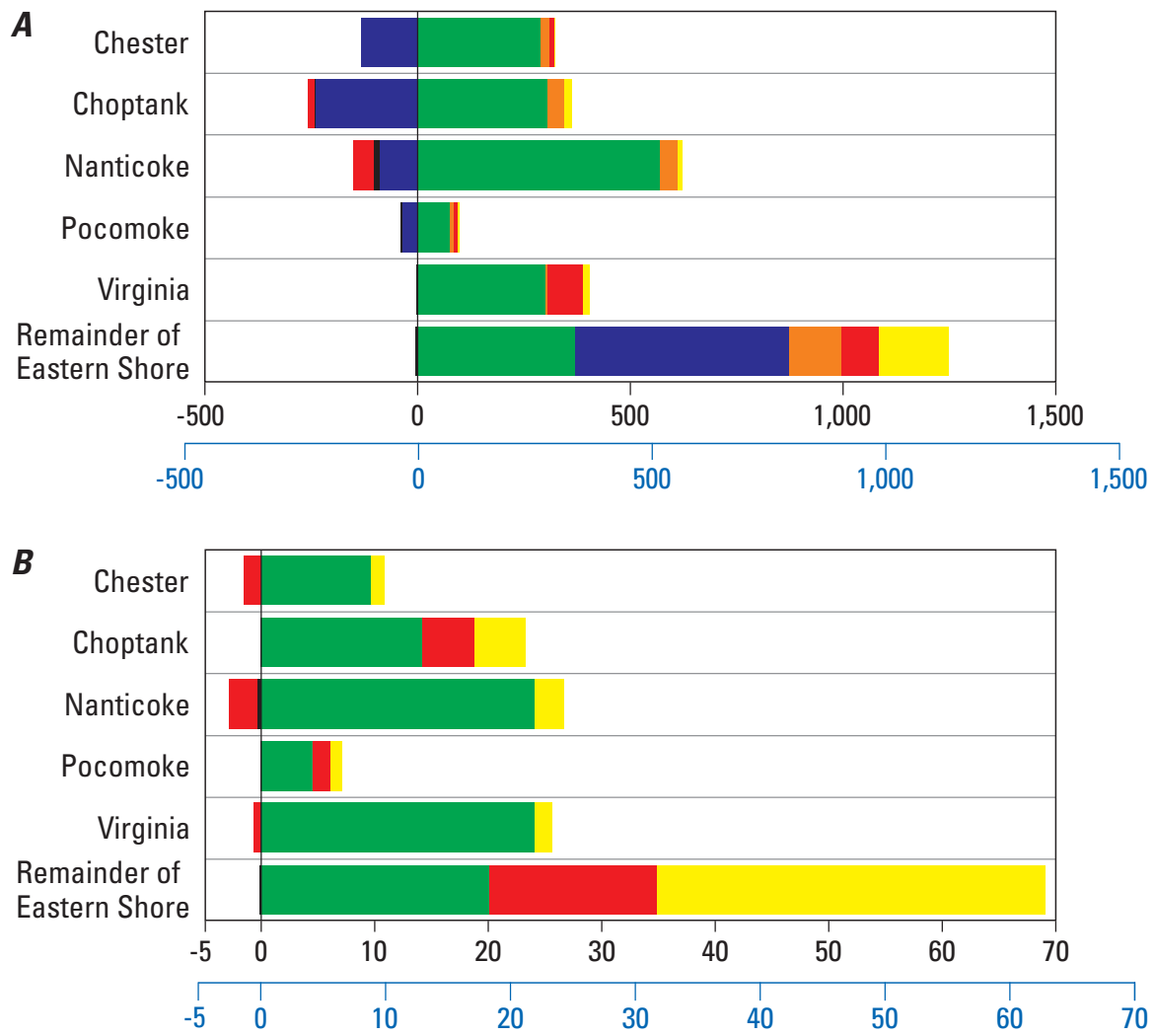

Required reduction from 2009 baseline to 2025 target,

$$
\begin{aligned}
& \text { in tons per year } \\
& \text { (metric tons per year) }
\end{aligned}
$$

[Required load reductions from Chesapeake Bay Program, 2014a.]

\begin{tabular}{|c|c|}
\hline & Agriculture \\
\hline & Atmospheric deposition directly \\
\hline & $\begin{array}{l}\text { to tidal or nontidal waters } \\
\text { Forest }\end{array}$ \\
\hline & Onsite septic systems \\
\hline & Wastewater and combined sewer \\
\hline & $\begin{array}{l}\text { overflows (CSOs) } \\
\text { Urban or regulated stormwater runoff }\end{array}$ \\
\hline
\end{tabular}

\section{EXPLANATION}

Figure 13. Reductions of $(A)$ nitrogen and $(B)$ phosphorus from nonpoint sources in major watersheds of the Eastern Shore required to meet a 2010 Total Maximum Daily Load (TMDL) for the Chesapeake Bay established under the Clean Water Act. Major watersheds are shown in figure 1. Where the reduction is negative, the 2009 baseline load is lower than the 2025 target. 


\section{Water-Quality and Restoration Challenges in Chesapeake Bay}

Chesapeake Bay extends for more than 300 kilometers $(\mathrm{km})$ from its headwaters in northern Maryland to its mouth in southern Virginia, and has a surface area of more than 11,000 square kilometers $\left(\mathrm{km}^{2}\right)$ (Langland and Cronin, 2003) (fig. 1). More than $240,000 \mathrm{~km}$ of tributary streams drain to the bay from a watershed that includes parts of Delaware, Maryland, New York, Pennsylvania, Virginia, West Virginia, and the District of Columbia. The bay is home to more than 3,700 different species of plants and animals (U.S. Environmental Protection Agency, 2008a) and supports commercial fisheries, tourism, international shipping, and other activities that are vital to the economy of the Mid-Atlantic region.

Chesapeake Bay and its nontidal tributaries have been degraded in recent decades by excessive nutrients (nitrogen and phosphorus) in the water column. Elevated concentrations of nutrients in the bay contribute to algal blooms and decreases in water clarity, submerged aquatic vegetation, and dissolved oxygen (Karlsen and others, 2000; Kemp and others, 2005; Fisher and others, 2006; Bricker and others, 2007; U.S. Environmental Protection Agency, 2008a). Algal production in temperate estuaries is often controlled primarily by nitrogen concentrations (Vitousek and others, 1997). Concentrations of both nitrogen and phosphorus may control ecological production and resulting impairments in Chesapeake Bay during different seasons, however, and phosphorus may be particularly important in the spring (Prasad and others, 2010). Impaired conditions have occurred periodically in Chesapeake Bay over the past 200 years, but have become particularly severe and frequent since the 1950s (Karlsen and others, 2000; Bratton and others, 2003; Kemp and others, 2005). Under the authority of the Clean Water Act, Chesapeake Bay was listed as "impaired" in 2000 and a Total Maximum Daily Load (TMDL) was established for the bay in 2010 (U.S. Environmental Protection Agency, 2011b; Linker and others, 2013; Shenk and Linker, 2013). The TMDL represents a detailed nitrogen and phosphorus budget for the watershed, and includes mandatory quantitative load reductions for nitrogen and phosphorus from specific sources and specific geographic areas (fig. 13).

Restoration efforts in the Chesapeake Bay watershed in recent decades have contributed to water-quality improvements but have been insufficient to meet ecological standards. Concentrations of nutrients in Chesapeake Bay are largely controlled by inputs from the bay watershed (Prasad and others, 2010), which are mainly controlled by natural variations in precipitation and streamflow over time (fig. 14). Changes in concentrations of nitrogen and phosphorus over time in streams when adjusted for such known effects of streamflow and season can be more indicative of the effects of changing sources, land management, or other human activities than changes associated with concentration alone (Langland and others, 2006). Such flow-adjusted concentrations have decreased substantially in many tributaries in recent decades, but continue to increase in others (Langland and others, 2006; Langland and others, 2013), particularly for nitrogen in areas like the Eastern Shore where nonpoint sources are important and groundwater is a major pathway for nitrogen transport (Hirsch and others, 2010). In spite of improved water quality in many bay tributaries, only 38 percent of tidal waters in the bay system met dissolved oxygen standards during the summer months of 2008, 2009, and 2010, and during 2010, water-clarity and chlorophyll-a goals were achieved in only 18 and 22 percent of tidal waters, respectively (fig. 15) (U.S. Environmental Protection Agency, 2011a). 

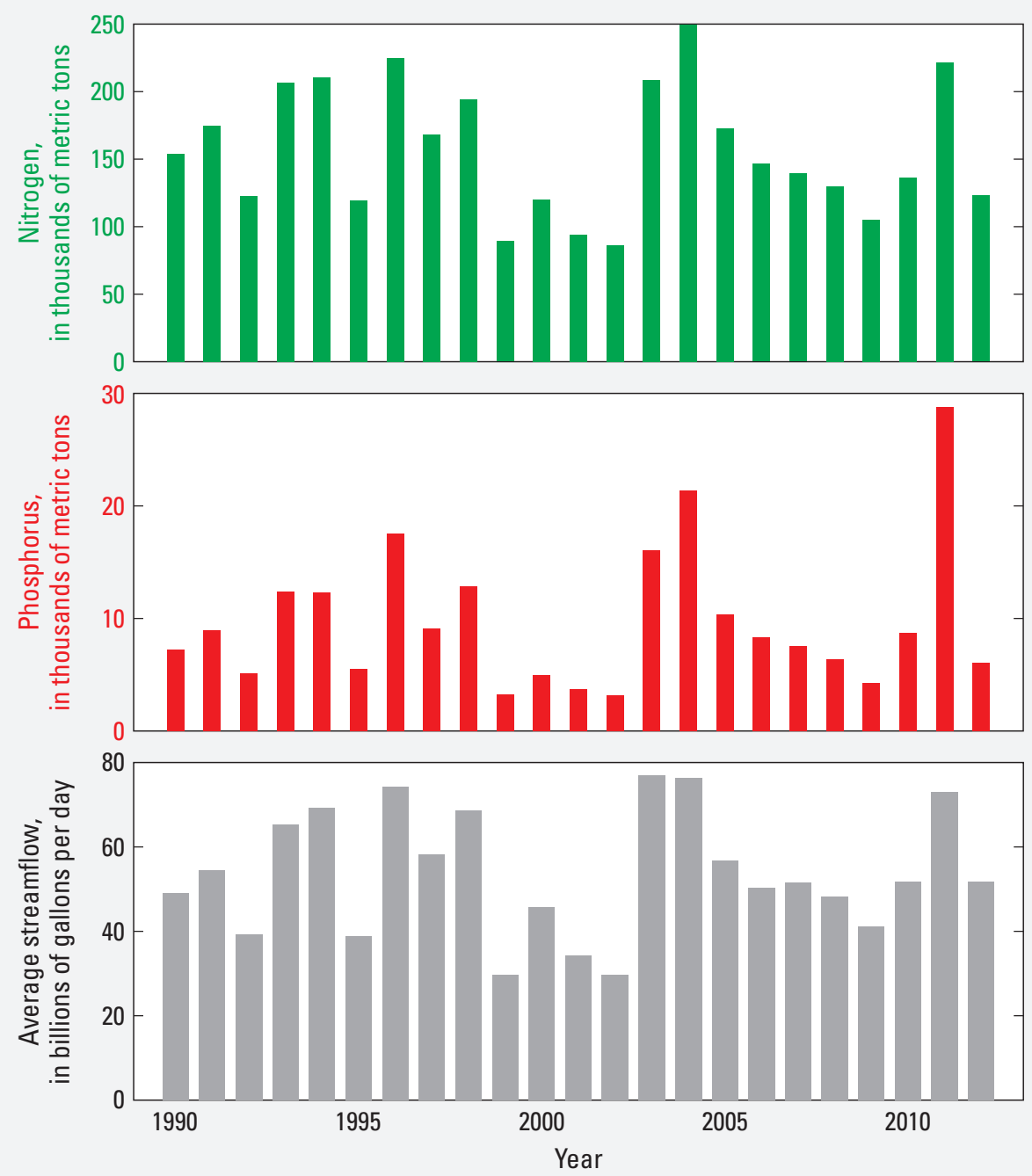

Figure 14. Annual streamflow and nitrogen and phosphorus loads delivered to Chesapeake Bay, 1990 through 2012. Loads of nitrogen and phosphorus reaching the bay from the watershed in any given year are controlled mainly by natural variation in precipitation and streamflow.

[Data from Chesapeake Bay Program, 2014b.]
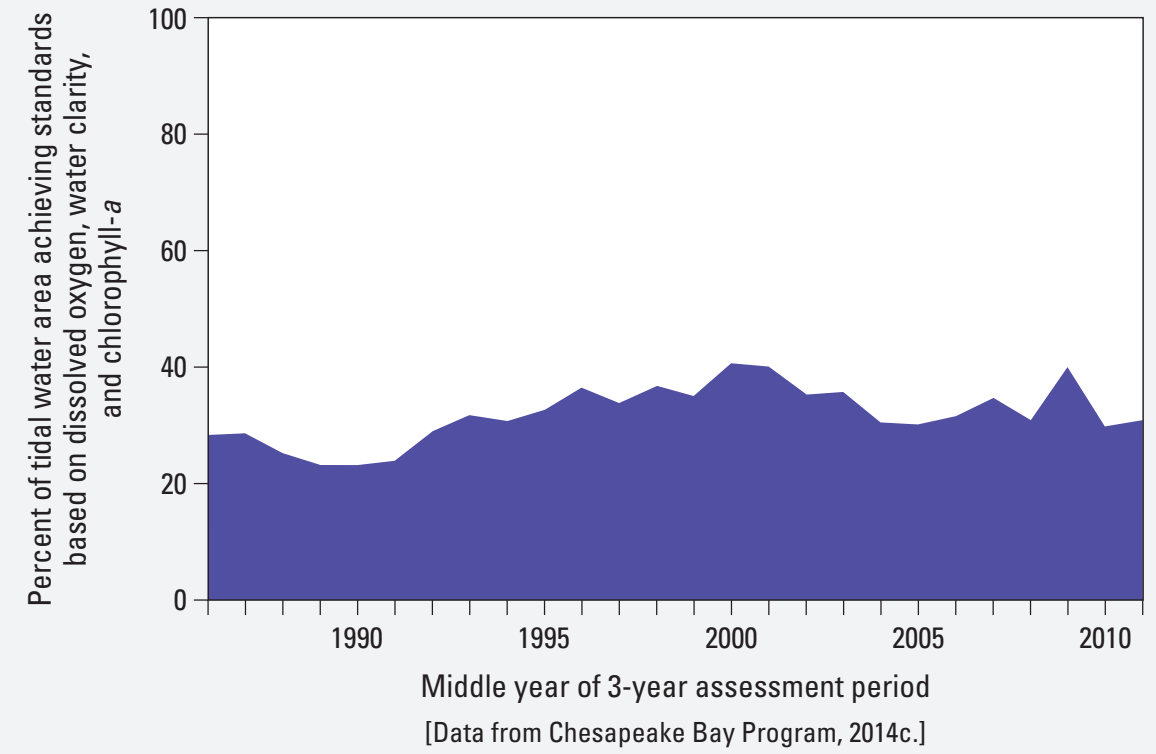

Figure 15. A summary of selected ecological conditions in Chesapeake Bay, 1985 through 2012. Although water quality in the bay varies substantially from year to year, ecological standards for dissolved oxygen, water clarity, and chlorophyll-a have not been attained in even half of tidal waters since the mid-1980s. 


\section{Environmental Setting of the Eastern Shore of Chesapeake Bay}

The Eastern Shore includes 11,200 square kilometers $\left(\mathrm{km}^{2}\right)$ of the Chesapeake Bay watershed east of the bay on the Delmarva Peninsula (fig. 1). The area includes parts of western Delaware and eastern Maryland and Virginia. The combination of hydrogeologic, soil, and climatic conditions on the Eastern Shore supports intensive agriculture, but also promotes the movement of nutrients from nonpoint sources (such as agricultural manure and fertilizer applications) from the land surface to groundwater, streams, and adjacent tidal waters of the bay.

\section{Land Use}

The Eastern Shore is predominantly rural and has been primarily agricultural for several hundred years (Allen, 2009) (fig. 16). Only 3 percent of the Eastern Shore is urban, including small towns such as Easton, Cambridge, and Salisbury, Maryland, and Seaford, Delaware. Historically, the area was almost entirely forested, although nearly all of the original forests had been cleared by the middle of the 18th century within 150 years of European settlement (Allen, 2009). In 2001, 49 percent of the Eastern Shore was used for agriculture, whereas 39 percent was regrown forests or wetlands (Wieczorek and LaMotte, 2010a). Many of the remaining forested areas occur in small isolated patches or in wetlands along streams; many of the original wetland marshes have been drained for cultivation or urban development (Allen, 2009).

Agriculture is an important economic resource on the Eastern Shore (fig. 16). Most agricultural land is used for row crops, primarily corn and soybeans for poultry feed, although plant nurseries, dairy farms, and other operations are present in some areas (Staver and Brinsfield, 2001; Denver and others, 2004). In 2012, more than 550 million broiler chickens were produced on the Delmarva Peninsula (U.S. Department of Agriculture, 2014). 

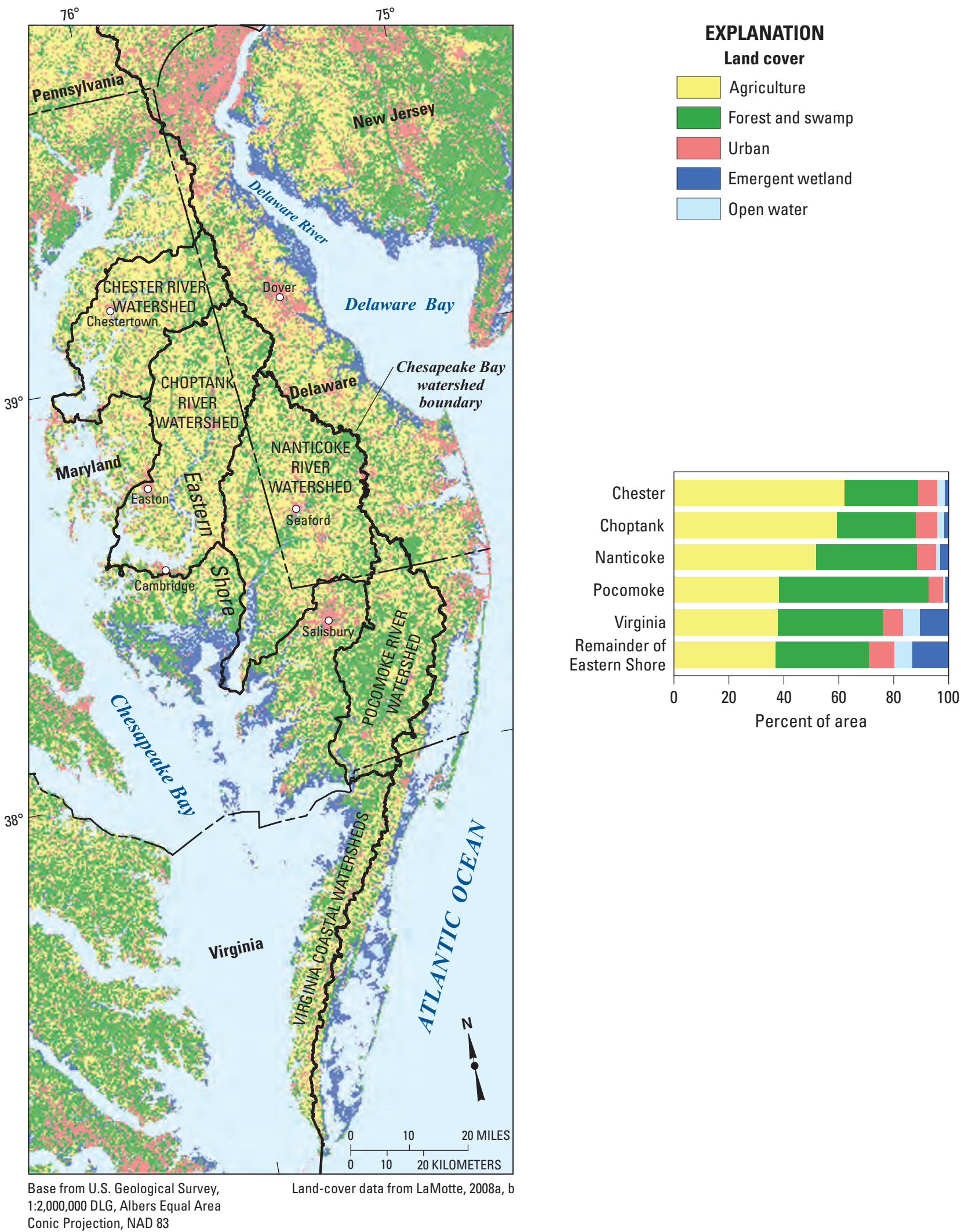

Figure 16. Major land use and land cover on the Eastern Shore, 2001. Agriculture, primarily corn and soybean production for poultry feed, is the predominant land use. 


\section{Geology and Soils}

The Eastern Shore is entirely within the Atlantic Coastal Plain, a relatively flat area that slopes gently from higher elevations in the Piedmont Physiographic Province to the north and west toward sea level at the Atlantic Coast (Fenneman and Johnson, 1946). The Eastern Shore landscape is particularly flat and low-lying, even more so than in other areas of the Coastal Plain to the west of the bay and to the north in New Jersey (fig. 17). The area is underlain by several thousand meters of unconsolidated sediments that vary laterally and vertically in texture and composition from relatively impermeable silt and clay to extremely permeable sand and gravel (Meng and Harsh, 1988; Mixon and others, 1989; Vroblesky and Fleck, 1991; Ator, Denver, Krantz, and others, 2005). The central core of the Delmarva Peninsula along the watershed divide is underlain at the surface by up to 30 or 40 meters (m) of generally coarse, permeable, and well-weathered (primarily quartz) sediment; younger surficial and near-surface sediments along the coast of the bay are typically finer in texture and less permeable (fig. 18). Soils on the Eastern Shore are generally sandy and permeable, but also vary in composition along with the underlying geologic parent material (fig. 19), and are poorly drained in many areas regardless of permeability due to the typically flat landscape (fig. 20). 


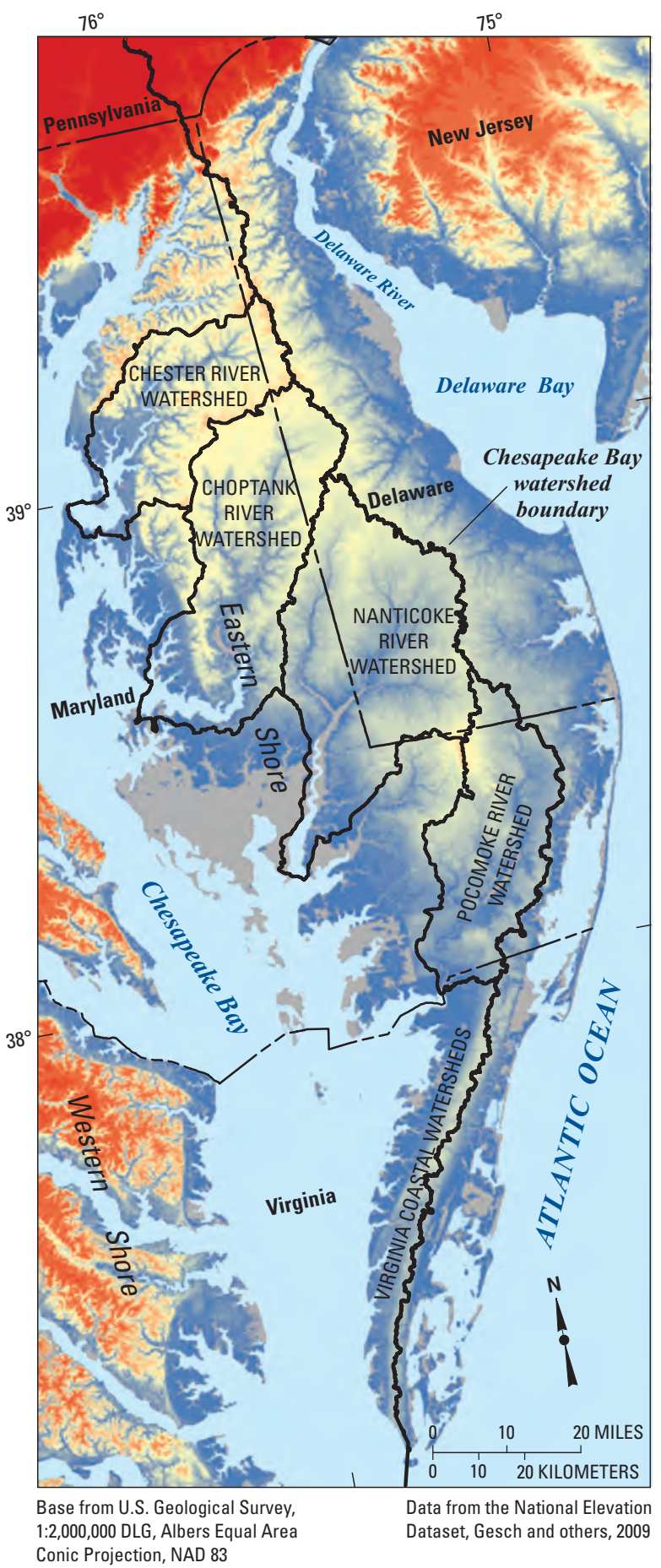

\section{EXPLANATION \\ Elevation, in meters}

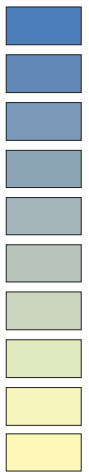

LE 2

GT2 and LE 4

GT 4 and LE 6

GT 6 and LE 8

GT 8 and LE 10

GT 10 and LE 12

GT 12 and LE 14

GT 14 and LE 16

GT 16 and LE 18

GT 18 and LE 20
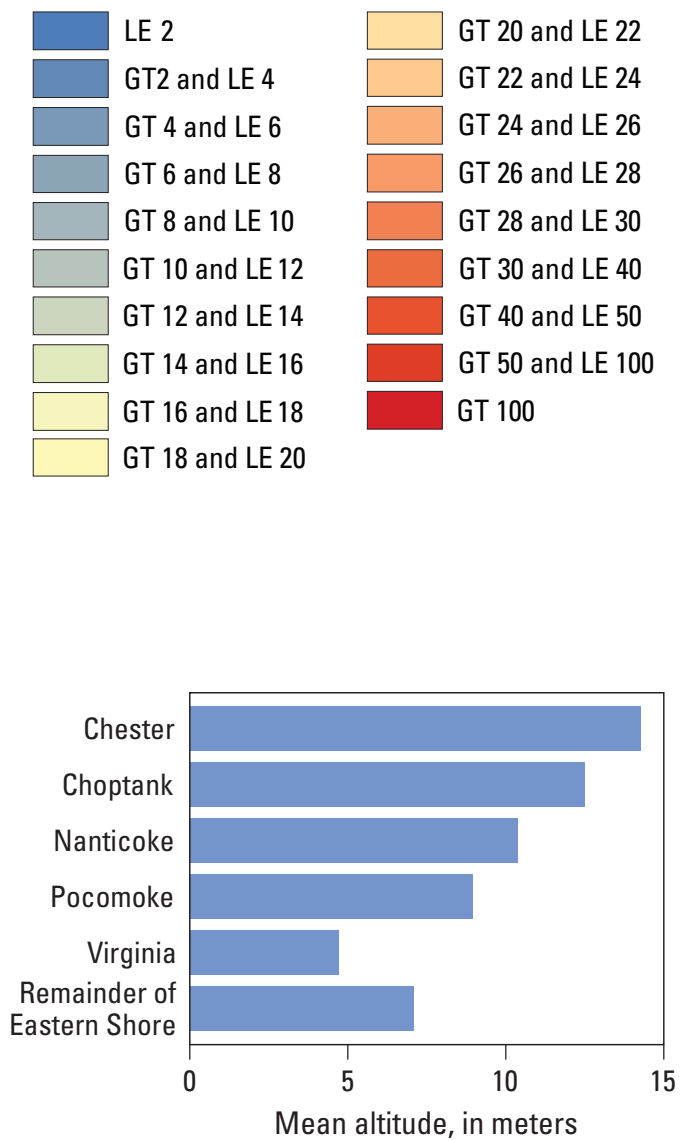

Figure 17. Landscape elevations on the Eastern Shore. The Delmarva Peninsula (including the Eastern Shore) is generally more flat and low-lying than surrounding areas of the Coastal Plain such as southern New Jersey and the Western Shore. ( $\mathrm{GT}$ = greater than; $\mathrm{LE}=$ less than or equal to.) 

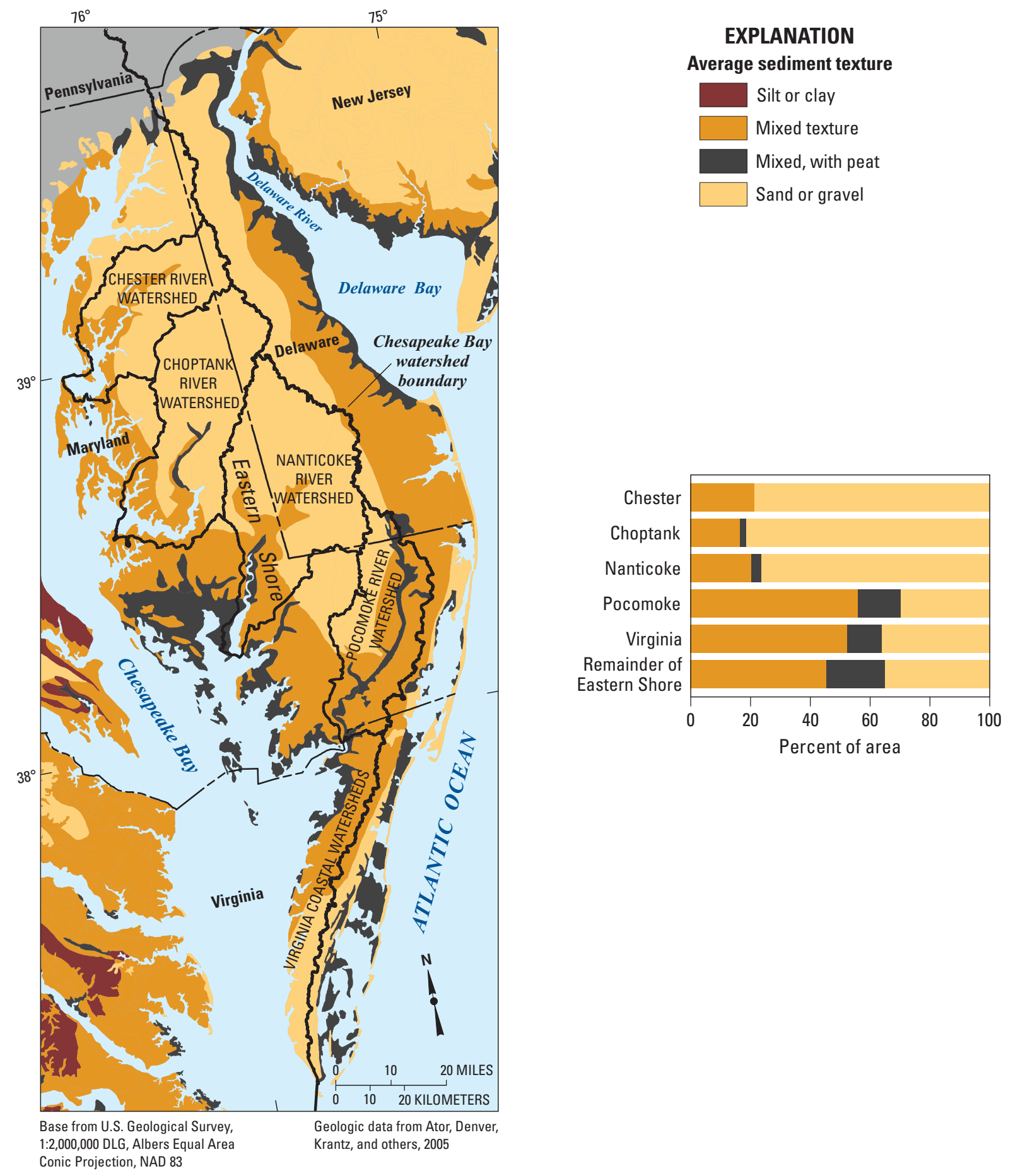

Figure 18. The average texture of surficial sediments on the Eastern Shore. Most near-surface sediments are relatively coarse and permeable sand or gravel, particularly in the central core of the Delmarva Peninsula. 

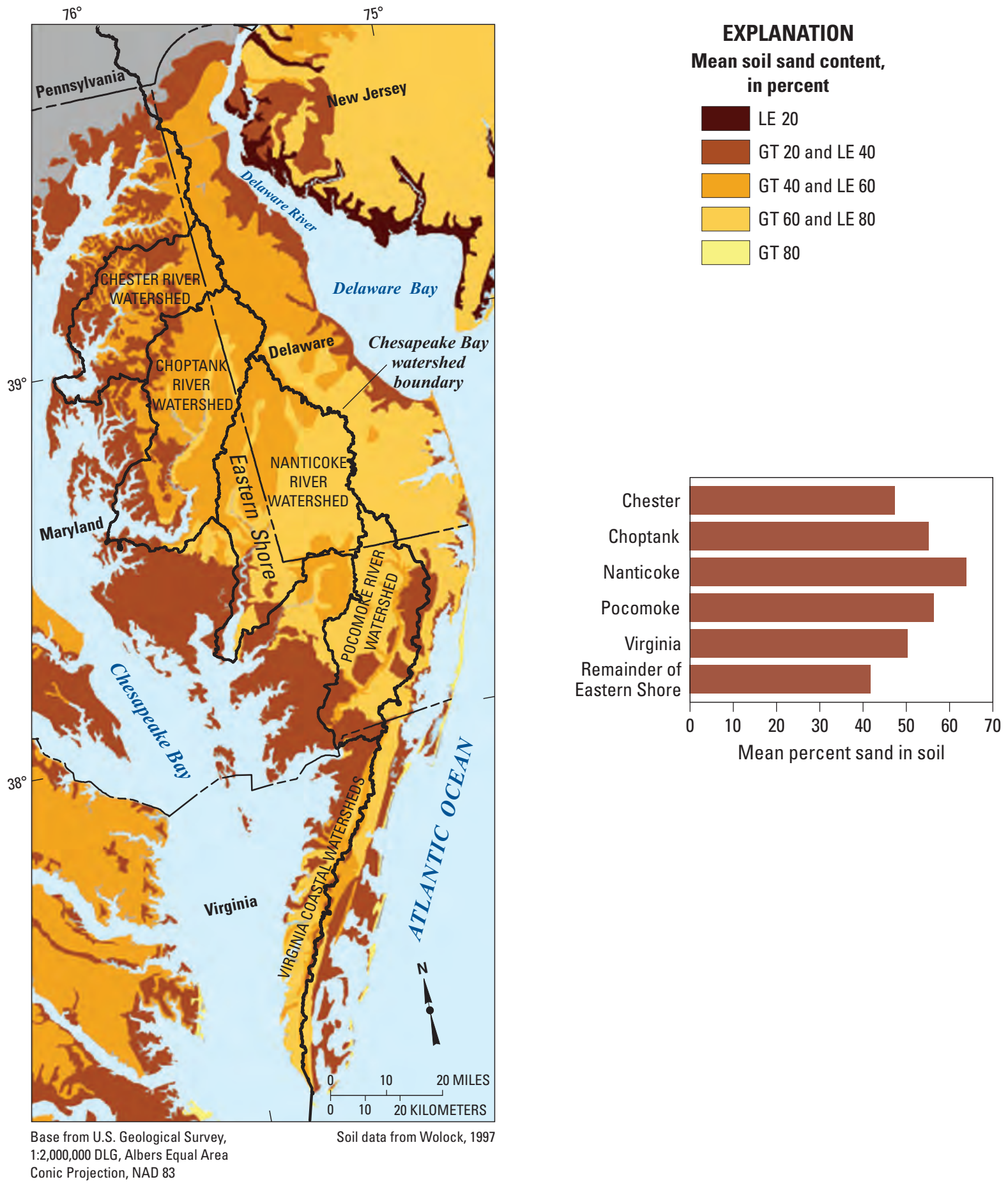

Figure 19. The sand content of Eastern Shore soils. Soils on the Eastern Shore are predominantly sandy, reflecting the texture of the underlying surficial sediments. (GT = greater than; $L E=$ less than or equal to.) 

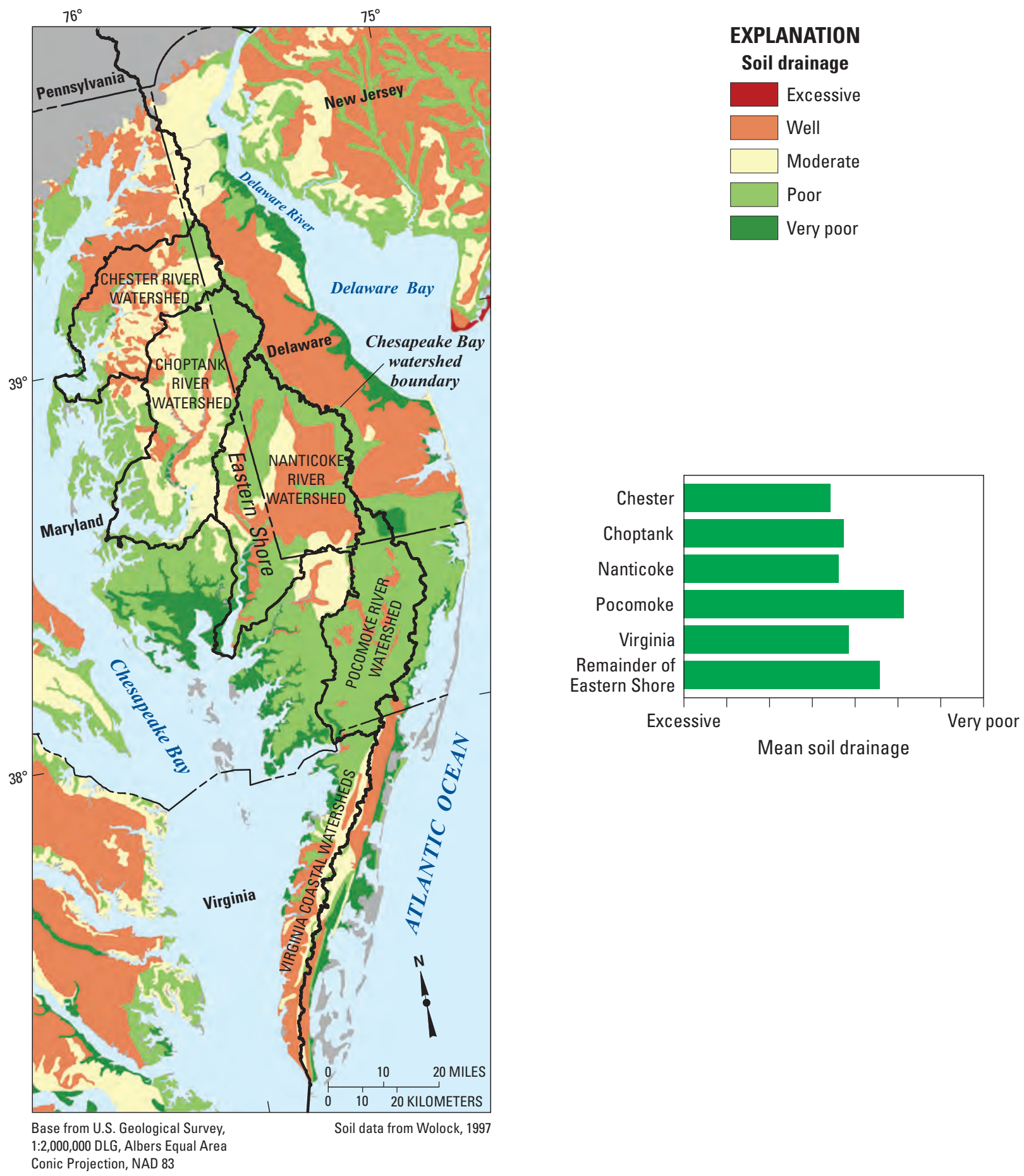

Figure 20. Soil drainage on the Eastern Shore. Drainage varies from well-drained to very poorly drained because of differences in geomorphology and soil texture. In spite of the generally coarse, sandy texture, soils in many areas are poorly drained due to the typically flat landscape. 


\section{Climate and Hydrology}

Hydrologic conditions on the Eastern Shore reflect the humid and temperate climate, a relatively flat landscape, and the texture and composition of soils and near-surface sediments. Annual precipitation on the Delmarva Peninsula averages around 112 centimeters $(\mathrm{cm})(44$ inches), the majority of which returns to the atmosphere through evaporation or transpiration by plants (fig. 21). The remaining water drains from the landscape through a network of nontidal streams and rivers or (in near-coastal areas) directly to tidal waters. Overland runoff of precipitation and occasional snowmelt contributes a small part (generally less than 25 percent in most areas) of streamflow on the peninsula. The majority of streamflow is generated by water that infiltrates through the soil to the water table and flows through groundwater to discharge areas in streams (Cushing and others, 1973; Hancock and Brayton, 2006; Sanford and others, 2012). The relative importance of groundwater flow and overland runoff to streamflow generation among different areas of the Eastern Shore reflects variations in topography (fig. 17), land-surface drainage (figs. 20, 22), and underlying soil (fig. 19) and geologic (fig. 18) conditions.

Most groundwater flows to nearby streams through the uppermost few meters of a shallow, surficial unconfined aquifer system that is generally less than $30 \mathrm{~m}$ thick (Sanford and others, 2012). The length and orientation of flow paths vary across the peninsula (fig. 21). Groundwater generally flows very slowly, often less than 1 meter per day $(\mathrm{m} / \mathrm{d})$ (Robinson and Reay, 2002). Consequently, several decades are often required for water to move from infiltration areas at the water table along groundwater flow paths to discharge areas in local streams, although water may discharge to streams from short, near-stream, flow paths within less than a year (figs. 21, 23) (Dunkle and others, 1993; Böhlke and Denver, 1995; Staver, 2010; Sanford and others, 2012). Most groundwater discharges to nontidal streams and rivers; a small fraction of groundwater (less than 2 percent) discharges directly from the peninsula to tidal waters in areas at or below sea level (Sanford and others, 2012).

More than half of the groundwater discharging to streams on the peninsula takes more than 13 years to move along groundwater flow paths from the water table to stream discharge areas. In contrast, in areas of the Chesapeake Bay watershed underlain by consolidated bedrock, less than 15 percent of groundwater discharging to streams is that old (Sanford and Pope, 2013). A small fraction (2 to 3 percent) of groundwater flows to confined aquifers that are present several hundred meters below the land surface. The age of groundwater in these aquifers can be centuries or older.

About one-third (35 percent) of the precipitation on the Eastern Shore drains from the landscape in streamflow to Chesapeake Bay. The majority of this water travels from upland landscapes to streams very slowly through groundwater over a period of multiple years or even decades. 


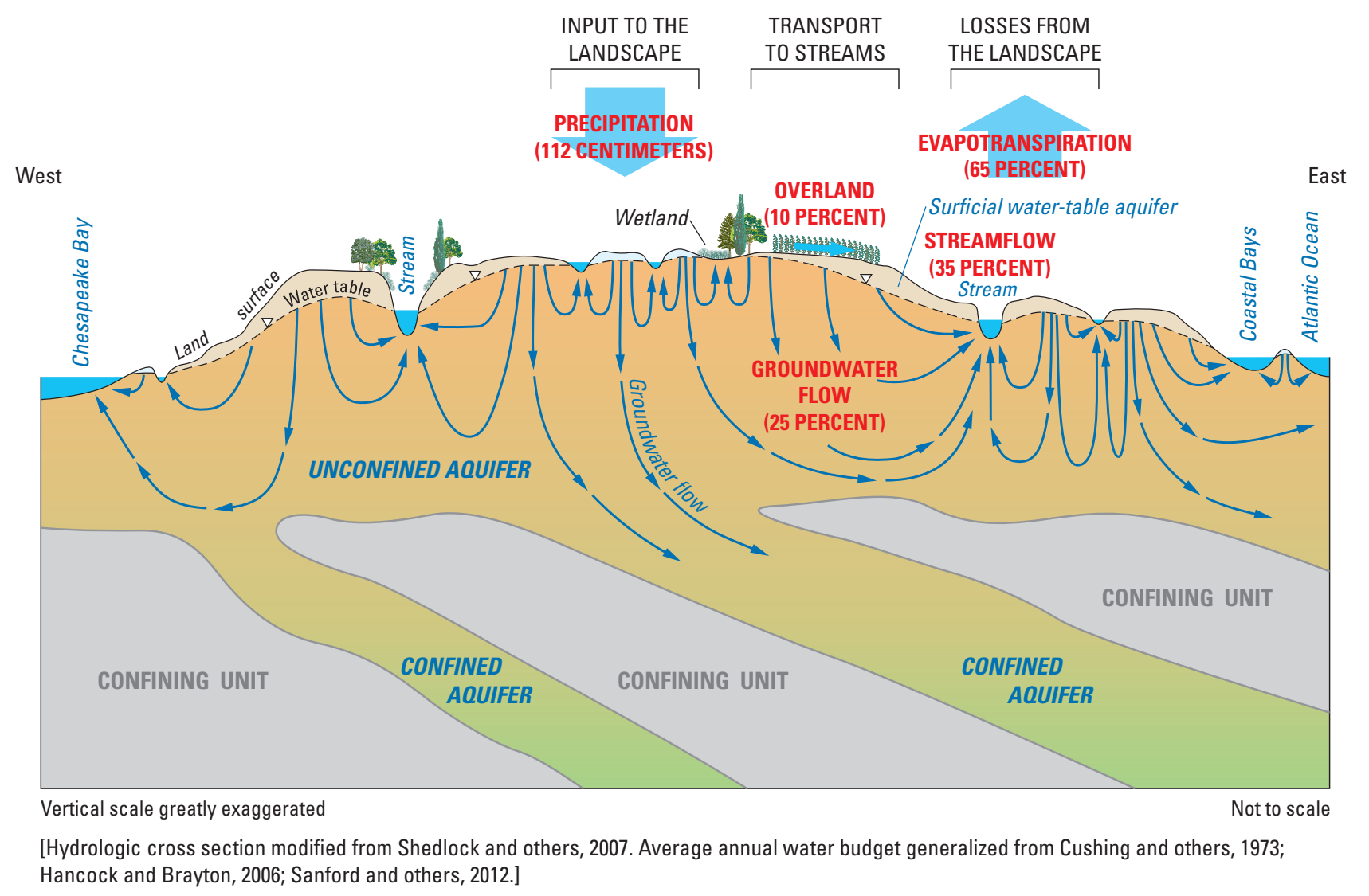

Figure 21. Conceptual hydrologic cycle and average annual water budget for the Eastern Shore. Most precipitation (65 percent) returns directly to the atmosphere through evaporation or transpiration by plants. The remaining water drains from the landscape in streamflow, most of which reaches streams through groundwater. 


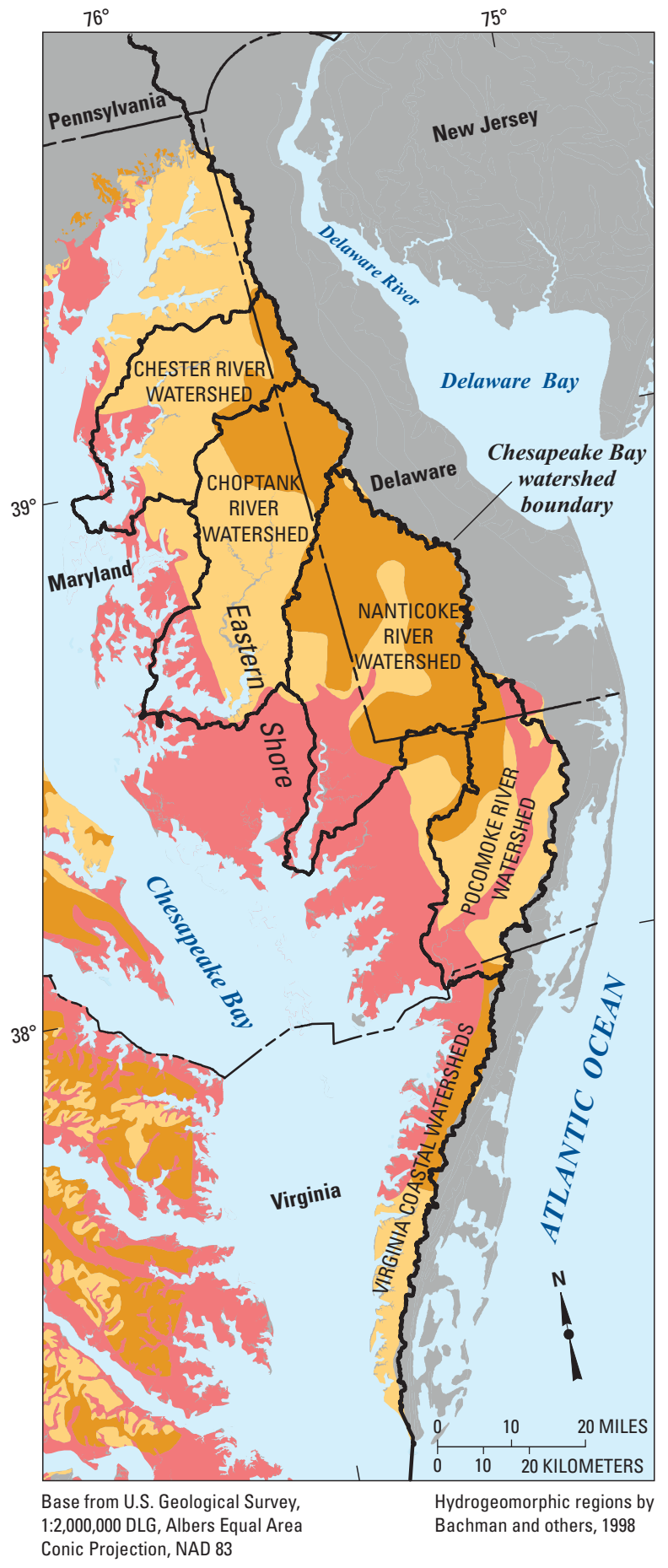

\section{EXPLANATION}

Hydrogeomorphic regions

Coastal Plain Upland: Located along
the major drainage divides in areas
with low relief and shallowly incised
stream valleys. Poorly drained forested
areas containing wetlands are interspersed
with moderately well- to well-drained
agricultural areas. Depressional wetlands
are common in the northern part of the area.
The water table is generally within 3 meters
of the land surface and ditching to lower the
water table and promote drainage is common.
Poor drainage is generally related to shallow
stream incision and high water table, rather
than to fine-grained sediments.

Coastal Plain Dissected Upland:

Area is relatively flat to gently rolling with predominantly well-drained soils underlain by sandy deposits. Stream channels are incised and the depth to water ranges from 3 to 10 meters below land surface. Most upland areas are used for agriculture with wooded areas generally confined to the incised sides of narrow riparian zones and flood plains.

\section{Coastal Plain Lowlands and Valleys:}

Located in lowlands underlain by generally fine-grained estuarine deposits in the tidal areas adjacent to the bay and in major river valleys. Area is very flat and poorly drained with the water table generally less than 3 meters below land surface. Wetlands, such as coastal marshes and broad riparian swamps along tidal rivers, are common. Parts of this area have been extensively ditched to lower the water table.

Figure 22. Variable hydrogeomorphic conditions among different areas of the Eastern Shore. Although mostly flat and low-lying, important differences in topography and drainage among different areas of the Eastern Shore contribute to variable land use and water quality. 


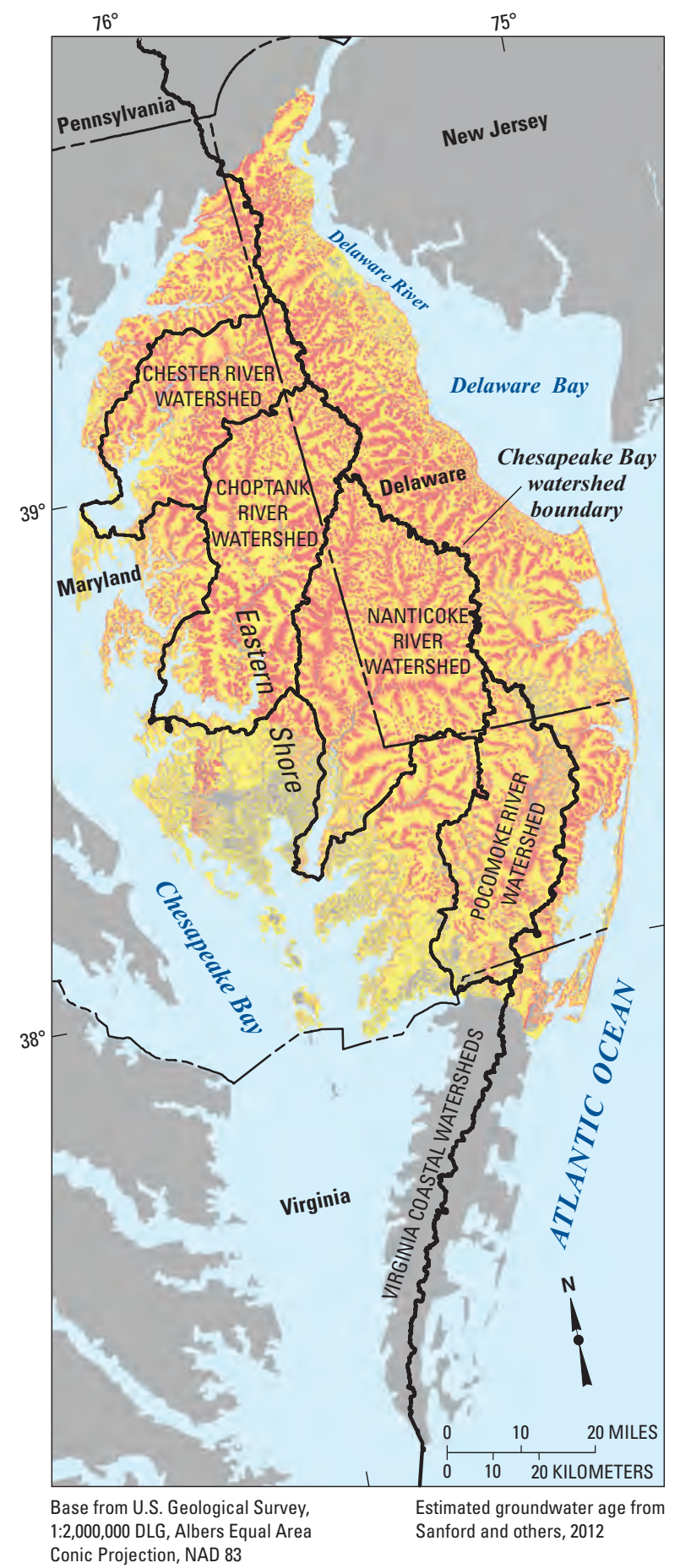

\section{EXPLANATION}

Age of groundwater, in years

LE 10

GT 10 and LE 20

GT 20 and LE 50

GT 50

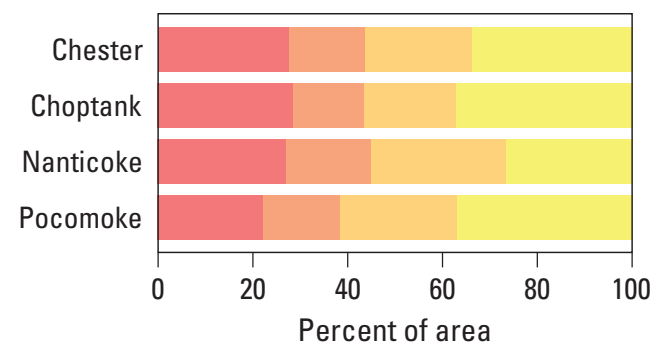

Figure 23. Estimated age of groundwater contributing to streamflow on the Eastern Shore. Most water flows along groundwater flow paths to local streams within a few decades, although much longer time periods are required for water recharging the water table along watershed divides. (GT = greater than; LE = less than or equal to.) 


\section{Chapter 3. Sources and Movement of Nitrogen and Phosphorus on the Eastern Shore}

\author{
Where do the nutrients, nitrogen and phosphorus, on the \\ Eastern Shore originate, and how do these nutrients move \\ from upland source areas to surface waters and Chesapeake \\ Bay?
}

Fertilizer and manure applied as part of agricultural operations are by far the predominant sources of nitrogen and phosphorus to the landscape on the Eastern Shore. Once on the land surface, nitrogen and phosphorus movement to surface waters occurs primarily through the action of water. Nitrogen is primarily transported to surface waters through groundwater in the form of nitrate. Conversely, phosphorus is predominantly transported over the land in runoff attached to sediment. The pathways and amounts of these chemicals entering surface waters are controlled by the amounts that have been applied in excess of crop uptake, differing chemical and physical properties of nitrogen and phosphorus compounds, and by varying hydrologic, geochemical, and geologic environments.

\section{Sources of Nitrogen and Phosphorus}

Agricultural sources supply the majority of nitrogen and phosphorus inputs to the land surface, groundwater, and nontidal streams on the Eastern Shore (fig. 24) (Staver and Brinsfield, 2001; Fisher and others, 2006; Whitall and others, 2010; Ator and others, 2011). More than half (53 percent) of the nitrogen reaching the Eastern Shore landscape is applied in inorganic fertilizers or fixed directly from the atmosphere in cropland; an additional 37 percent is contributed by manure. Less than 10 percent of nitrogen applied to the Eastern Shore is contributed by non-agricultural sources, including atmospheric deposition, septic systems, and urban sources (fig. 24) (Debrewer and others, 2007; Ator and others, 2011). Phosphorus sources to the landscape on the Eastern Shore are

Agriculture contributes more than 90 percent of the nitrogen and phosphorus to the Eastern Shore. similarly almost exclusively from agricultural applications of fertilizers (44 percent) and manure (56 percent) (fig. 24). In the Chesapeake Bay watershed as a whole, livestock produce 36 billion kilograms $(\mathrm{kg})$ of manure annually, approximately 10 times the mass produced by the watershed's human population (Kleinman and others, 2012). Much of the livestock is concentrated in poultry production on the Eastern Shore. Although nonpoint sources provide the majority of nutrients to the land surface and nontidal streams on the Eastern Shore, some point sources discharge directly to tidal waters and may be the predominant source of phosphorus locally to parts of some sub-estuaries of the bay (Boynton and others, 1995; Whitall and others, 2010).

Fertilizer applications and poultry production on the Eastern Shore have increased substantially in recent decades (fig. 25) and nitrogen and phosphorus applications to cropland typically exceed the amounts removed in crops during harvest (fig. 26). Although land use on the Delmarva Peninsula has been primarily agricultural for several hundred years (Allen, 2009), applications of nitrogen in fertilizer increased from less than 10 million $\mathrm{kg} / \mathrm{yr}$ in 1950 to around 60 million kg/yr in 1980 (fig. 25) (Alexander and Smith, 1990; Battaglin and Goolsby, 1995; Mid-Atlantic Water Program, 2012). Applications of phosphorus in fertilizer similarly increased during that period, but have since decreased. Poultry production on the Delmarva Peninsula has also increased in recent decades from less than 4 million broilers in 1919 to nearly 600 million by 2007 (fig. 25) (U.S. Department of Agriculture, 2009). Applications of nitrogen and phosphorus from these sources to croplands on the Eastern Shore have exceeded crop needs since at least the 1980s (fig. 26) (Mid-Atlantic Water Program, 2012).

Although agriculture has been a primary land use on the Eastern Shore for several centuries, poultry production and applications of nitrogen fertilizer increased substantially during the latter half of the 20th century.

Applications of nitrogen and phosphorus to cropland on the Eastern Shore typically exceed amounts that are incorporated into crop growth and removed at harvest. 
INPUTS, IN THOUSAND KILOGRAMS PER YEAR

(PERCENT OF TOTAL)

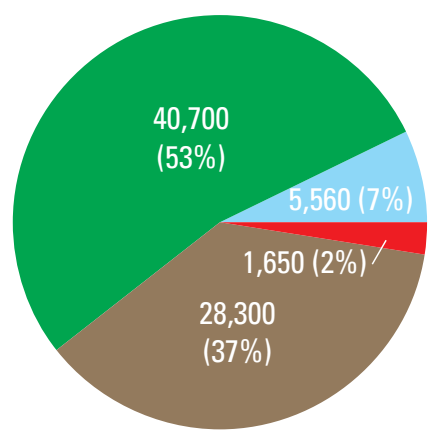

NITROGEN

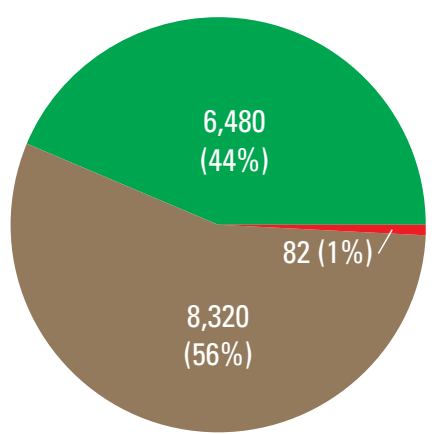

PHOSPHORUS

\section{SOURCE}

Fertilizer applications or (for nitrogen) direct fixation from the atmosphere by crops (Wieczorek and LaMotte, 2010b).

Manure (Wieczorek and LaMotte, 2010c).

Atmospheric deposition (Wieczorek and LaMotte, 2010d).

Other, including point sources (U.S. Environmental Protection

Agency, 2009) and septic systems (Maizel and others, 1997).

Figure 24. Annual inputs of nitrogen and phosphorus from various sources to the Eastern Shore. Agriculture provides more than 90 percent of both nitrogen and phosphorus applications.

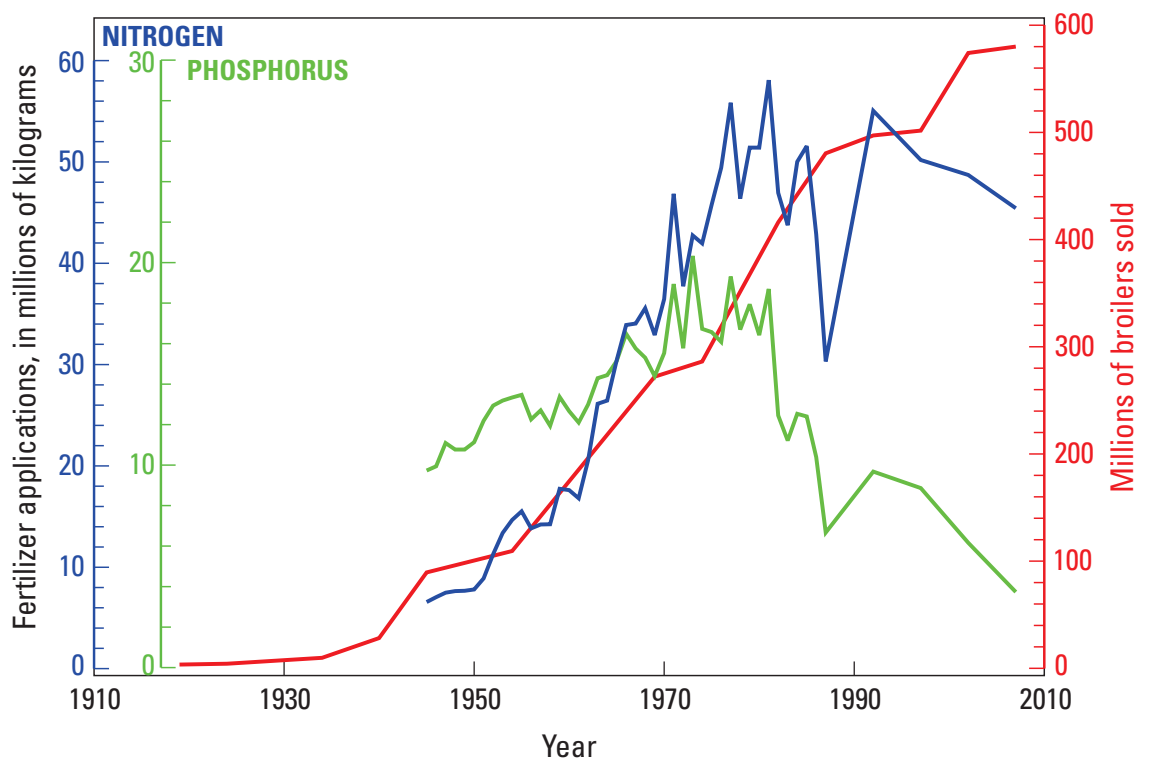

[Broiler data are from U.S. Department of Agriculture, 2009. Estimates prior to 1950 are for total chickens or broilers raised. Fertilizer inputs are from Alexander and Smith, 1990, Battaglin and Goolsby, 1995, and Mid-Atlantic Water Program, 2012.]

Figure 25. Past poultry broiler production and fertilizer applications on the Delmarva Peninsula. Broiler production has increased consistently and substantially since the early part of the 20th century. Nutrient applications to cropland on the Peninsula similarly increased between the 1950s and 1980s, but have decreased or remained relatively consistent since that time. 


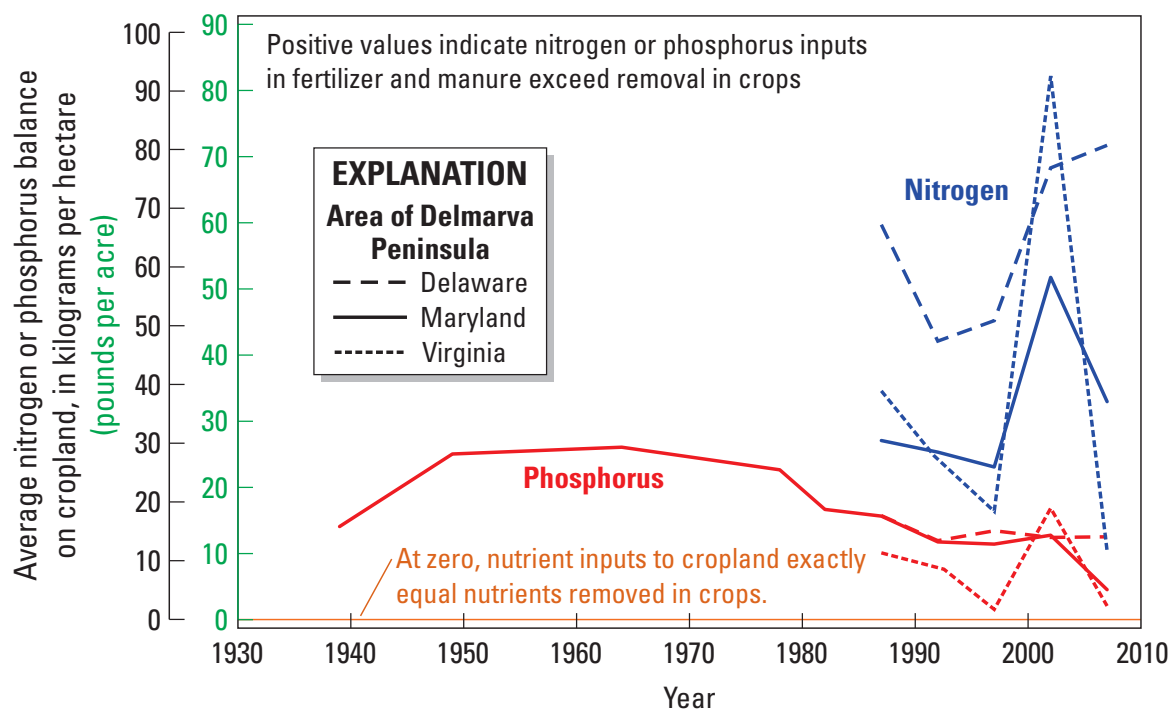

[Balances were computed from estimates of Mid-Atlantic Water Program, 2012.]

Figure 26. Average annual balance between inputs (primarily in fertilizer and manure) and outputs (primarily in harvested crops) of nitrogen and phosphorus on cropland on the Delmarva Peninsula in recent decades. Nitrogen and phosphorus applications to cropland have consistently exceeded removal during harvest, leaving excess nutrients available in the environment for transport to groundwater and (or) streams.

\section{Movement of Nitrogen and Phosphorus from Source Areas to Surface Waters}

Nitrogen and phosphorus compounds move from upland source areas to streams and groundwater on the Eastern Shore primarily through the action of water. Pathways most important to nutrient transport in different areas therefore depend primarily on local hydrologic and geologic conditions that control water movement, including the slope of the land surface and the texture, thickness, and permeability of soils and geologic sediments. Also important are chemical and physical properties of different compounds and local geochemical conditions, since they control the solubility of nitrogen or phosphorus compounds in water and the likelihood of their persistence in water or transformation to other forms (Dubrovsky and others, 2010).

Nitrogen and phosphorus occur in a variety of forms in streams and groundwater. Nitrogen in chemical fertilizers and atmospheric deposition generally reaches the land in inorganic forms such as ammonia $\left(\mathrm{NH}_{3}\right)$, ammonium $\left(\mathrm{NH}_{4}^{+}\right)$, or nitrate $\left(\mathrm{NO}_{3}^{-}\right)$, whereas nitrogen in animal wastes (such as poultry manure) and septic effluent often occur in ammonium or organic compounds. Much of the applied nitrogen is converted in the soil to nitrate, which remains stable in groundwater as long as dissolved oxygen is present, and is the most common form of nitrogen in groundwater and streams of the Eastern
Shore (Denver and others, 2004; Ator, Denver, and Brayton, 2005; Debrewer and others, 2007) and elsewhere (Dubrovsky and others, 2010). Phosphorus is less soluble than nitrate and commonly occurs in solid form bound to soils or sediment particles, although some phosphorus may dissolve in streams or groundwater in the form of phosphate $\left(\mathrm{PO}_{4}^{3-}\right)$ (Dubrovsky and others, 2010).

\section{Nitrogen}

Nitrogen moves from source areas on the landscape to surface waters of the Eastern Shore primarily through groundwater in the form of nitrate (Böhlke and Denver, 1995; Ator, Denver, and Brayton, 2005; Ator and Denver, 2012). Because nitrate is very soluble, it dissolves easily in rainfall or other water as it infiltrates through the soil toward the water table. Once below the water table, nitrate similarly moves slowly with groundwater to withdrawal wells or to discharge areas in surface waters (fig. 27). Although nitrate remains stable for long time periods in groundwater containing abundant dissolved oxygen, it is converted to nitrogen gas and lost from groundwater (through a process called "denitrification") where dissolved oxygen is lacking. On the Eastern Shore, hydrogeologic conditions controlling the effectiveness of denitrification in groundwater are quite variable from place to place; groundwater generally contains more nitrate in areas with abundant 
dissolved oxygen than in areas where oxygen is limited (Debrewer and others, 2007) (fig. 28), and denitrification removes minimal nitrogen from groundwater discharging to some Eastern Shore streams but substantial nitrogen in others (see sidebar: "Nitrate Removal Through Denitrification, and Limitations Caused by Local Hydrogeology"). Hydrogeologic conditions in many areas are conducive to nitrate transport from groundwater to streams, however, and 70 percent of the nitrogen load from Eastern Shore streams to Chesapeake Bay reaches streams as nitrate through groundwater (Domagalski and others, 2008; Ator and Denver, 2012). Hydrogeologic conditions in aquifer discharge areas and the resulting interactions between groundwater and surface waters are complex and variable among and within individual streams, and nitrate contributions from groundwater may occur through diffuse or spatially concentrated seepage through the streambed or along flood-plain seeps (Domagalski and others, 2008; Knee and Jordan, 2013).

Nitrogen moves from source areas on the landscape to streams and tidal waters of the Eastern Shore primarily as nitrate through groundwater.

Groundwater discharge contributes nitrate directly to tidal estuaries adjacent to the Delmarva Peninsula through submarine groundwater discharge (Reay and others, 1992; Gallagher and others, 1996; Speiran, 1996; Staver and Brinsfield, 1996; Bratton and others, 2004) as well as to nontidal tributary streams (fig. 27). Less than 10 percent of freshwater from the Eastern Shore reaches the bay directly through submarine groundwater discharge (Hussain and others, 1999; Sanford and others, 2012); most freshwater flow to Chesapeake Bay occurs through nontidal tributary streams. Groundwater discharge of nitrate directly to coastal bays along the Atlantic margin of the Delmarva Peninsula is similarly much smaller than groundwater discharge of nitrate to nontidal tributaries (Dillow and Greene, 1999), although the relative importance of such discharge to Chesapeake Bay is unknown. Nitrate contributions from submarine groundwater discharge may be limited by anoxic conditions in estuarine sediments (Bratton and others, 2004; Bratton and others, 2009) and - as in nontidal streams - likely vary with variable hydrogeologic conditions over different areas (Speiran, 1996; Krantz and others, 2004; Manheim and others, 2004; Knee and Jordan, 2013). Direct discharge of nitrate from groundwater to tidal creeks is limited by fine-grained organic-rich sediments and associated anoxic conditions in the northern part of the Eastern Shore in Virginia, for example, but promoted by coarser organic-poor sediments to the south (Speiran, 1996).

Nitrogen in organic compounds or other forms also moves to surface waters over the land surface during overland runoff following precipitation, and may constitute a substantial part of in-stream nitrogen loads during such periods, particularly in the spring following fertilizer and manure applications, but before major crop growth. Groundwater discharge as base flow provides the majority of streamflow on the Eastern Shore, however, and nitrate from groundwater discharge constitutes the majority of nitrogen in nontidal streams (Ator and Denver, 2012). Nitrate concentrations often decrease in streams during high-flow periods, as relatively high concentrations contributed from groundwater discharge are diluted by overland runoff containing lower nitrate concentrations (fig. 29).

Nitrate in surface waters on the Eastern Shore represents a mixture of nitrogen contributed to the land surface in the upstream watershed over a variety of time periods. Groundwater generally flows very slowly, and nitrate concentrations in groundwater therefore reflect application rates and other influences during previous periods when the water actually infiltrated from the land surface to the water table. Nitrate moving through the soil to the water table close to streams and other discharge areas may flow along short groundwater flow paths to streams within a few years. However, several years or decades are typically required for nitrate movement through the surficial aquifer from source areas to streams (fig. 23), and even greater time periods are often required for flow along longer flow paths from watershed uplands (fig. 27) (Dunkle and others, 1993; Böhlke and Denver, 1995; Lindsey and others, 2003; Debrewer and others, 2007; Sanford and Pope, 2007; Denver and others, 2010). Groundwater discharge to streams therefore represents a mixture of flow paths of differing ages from throughout the stream watershed (fig. 27), and nitrate in streams during base flow is a mixture of nitrogen applied during many different time periods (Lindsey and others, 2003; Sanford and others, 2012). 


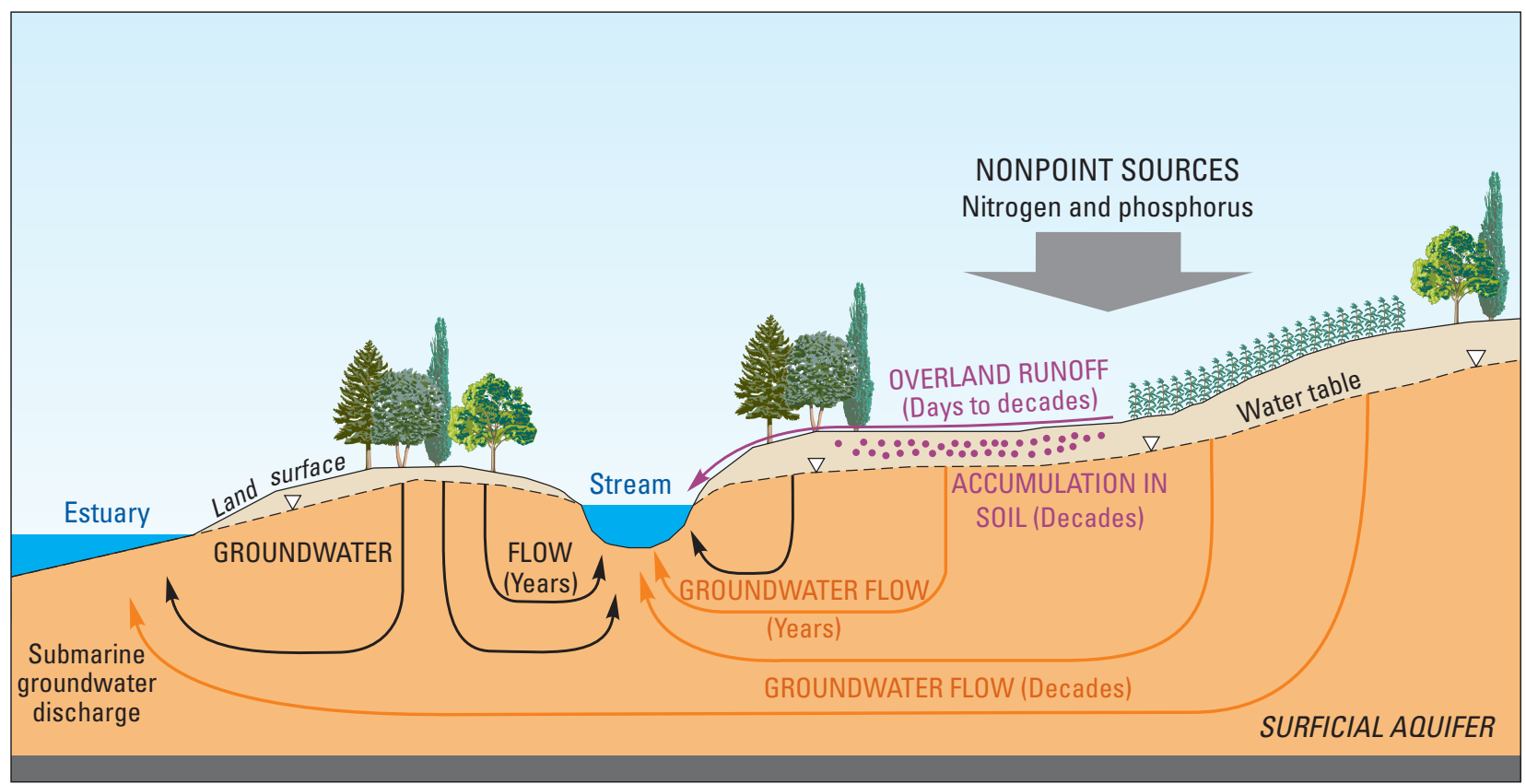

\section{EXPLANATION}

Hydrogeologic units

Unsaturated zone above the water table

Aquifer with oxic groundwater

Confining unit

\section{Flow path or storage location}

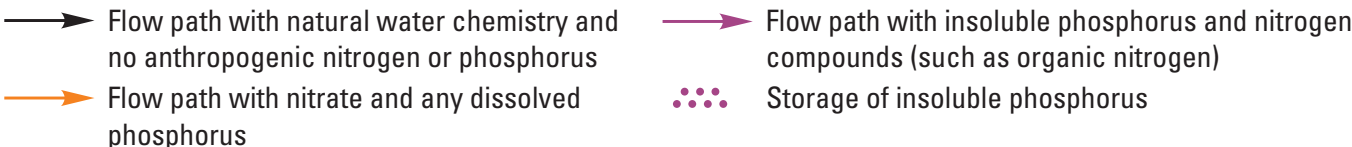

Figure 27. Idealized summary of hydrology and nutrient transport on the Eastern Shore in areas with oxic groundwater and well-drained soils. Nitrogen transport from the land surface to streams occurs primarily through groundwater in the form of nitrate, whereas phosphorus transport occurs primarily in overland runoff.

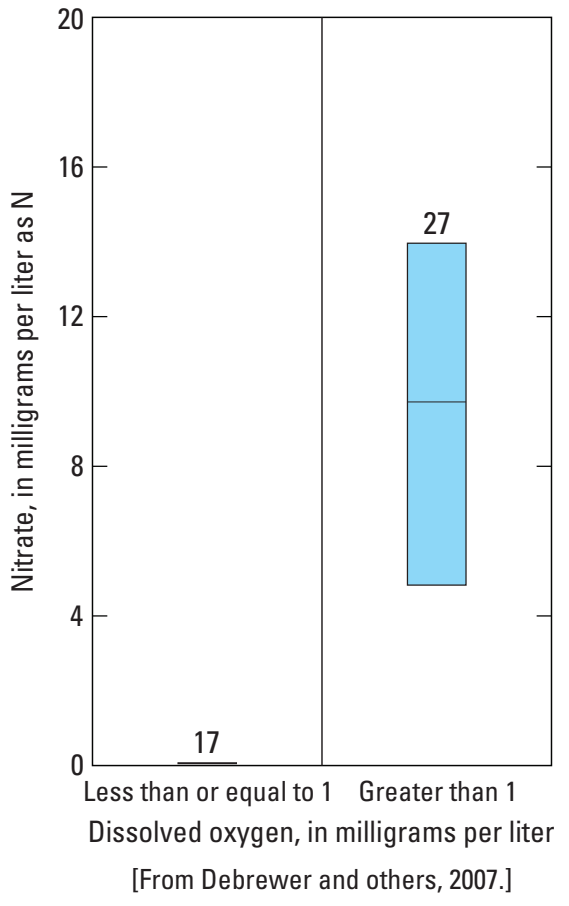

\section{EXPLANATION}

$27 \begin{aligned} & \text { Number of } \\ & \text { samples } \\ & 75 \text { th }\end{aligned}$
$\begin{aligned} & \text { percentile } \\ & \text { Median } \\ & \text { 25th } \\ & \text { percentile }\end{aligned}$

Figure 28. The importance of dissolved oxygen concentrations to nitrate concentrations in shallow groundwater on the Delmarva Peninsula, 2001. Nitrate concentrations are typically much higher in groundwater containing abundant dissolved oxygen than in groundwater where dissolved oxygen is low (less than 1 milligram per liter). 


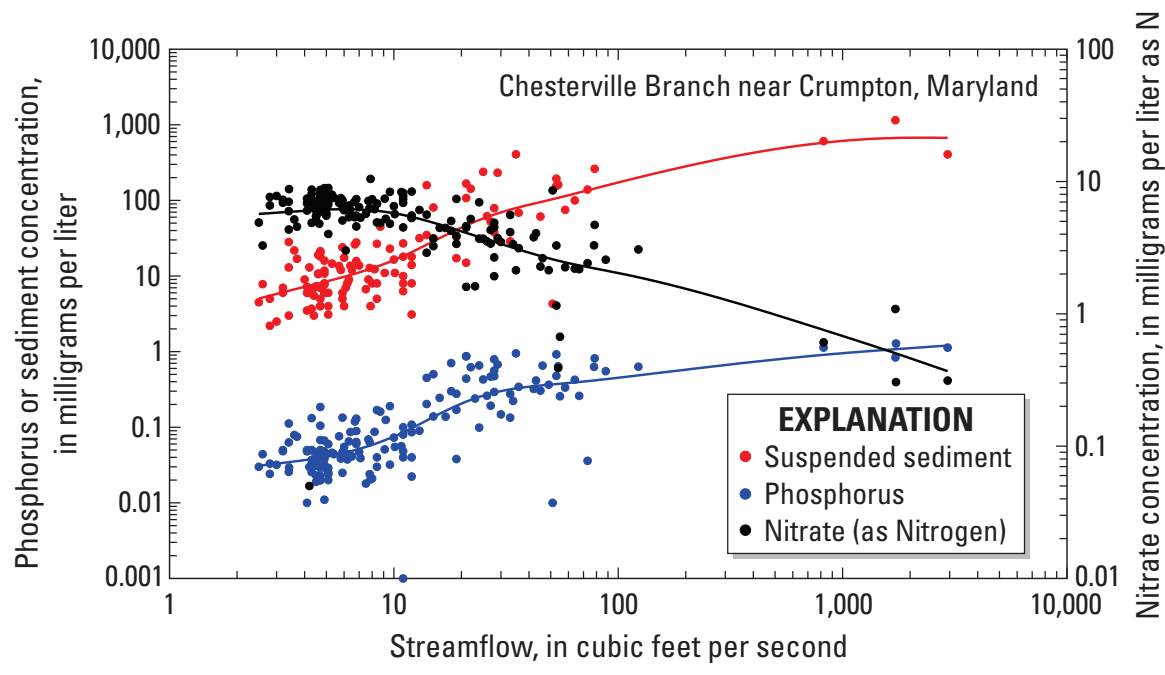

[From Ator, Denver, and Brayton, 2005.]

Figure 29. Relation of concentrations of nitrate, phosphorus, and suspended sediment to streamflow in Chesterville Branch, 1990-2012. Decreasing nitrate concentrations but increasing phosphorus and sediment concentrations during periods of increased streamflow indicate that different mechanisms are primarily responsible for the transport of these contaminants to Chesterville Branch. Nitrate moves to Chesterville Branch primarily through groundwater, and concentrations are highest during low-flow periods when streamflow is primarily contributed by groundwater discharge. Sediment and phosphorus, conversely, are lowest during low flow and move to Chesterville Branch primarily through overland runoff during high-flow periods. 


\section{Nitrate Removal Through Denitrification, and Limitations} Caused by Local Hydrogeology

itrogen is transported as nitrate through groundwater to streams with minimal losses in water with abundant dissolved oxygen, but can be lost in substantial quantities to the atmosphere in anoxic areas (fig. 30). Precipitation generally contains abundant dissolved oxygen from the atmosphere as it infiltrates through the soil to the water table. Where soils and aquifer sediments contain little organic material (as in many areas of the Eastern Shore), water remains oxic (retains dissolved oxygen) and nitrate remains stable for long time periods as the water infiltrates to the water table and moves along groundwater flow paths to streams and coastal estuaries. In organic-rich soil and aquifer sediments, however, dissolved oxygen is consumed and anoxic conditions develop as naturally occurring bacteria consume the organic matter. In such geochemical environments, nitrate becomes unstable and is lost to nitrogen gas through denitrification, an important process for removing nitrate from terrestrial ecosystems worldwide (Howarth and others, 1996).

Denitrification may substantially reduce nitrogen delivery to streams in some areas of the Eastern Shore, but has limited effect on nitrogen loads in streams in other areas where groundwater flow largely bypasses anoxic conditions. Denitrification has been observed in many different settings on the Eastern Shore, including at or near the land surface in soils of depressional (Denver and others, 2014) and riverine (Jordan and others, 2007) wetlands, along groundwater flow paths (Böhlke and Denver, 1995; Denver and others, 2010), in riparian flood plains (Duff and others, 2008; Puckett and others, 2008), and in coastal swamps and marshes (Speiran, 1996). The importance of denitrification to overall nitrogen delivery to individual streams, however, depends on the local hydrogeology, particularly the orientation of groundwater flow paths and the extent to which groundwater containing nitrate encounters anoxic conditions prior to discharging to streams (Denver and others, 2014). Nitrate in groundwater is most likely to encounter anoxic conditions conducive to denitrification where the surficial aquifer is particularly thin (figs. 30-1b, 30-1c, 30-4). The surficial aquifer in many areas of the Eastern Shore is relatively thick, however, and anoxic conditions associated with wetlands on the land surface in such areas often do not extend through the entire thickness of the aquifer (fig. 30-2a) or have been truncated by artificial ditching or channelization (fig. 30-3). In such areas, oxic groundwater carries nitrate to streams beneath forested stream buffers (fig. 30-1a) or denitrifying conditions at the land surface (fig. 30-2a). Nitrate concentrations are generally much higher in streams in areas where these conditions are common (such as the Eastern Shore) than in other areas of the Atlantic Coastal Plain (such as, for example, the Western Shore) where the surficial aquifer is typically much thinner (Vroblesky and Fleck, 1991; Ator, Denver, Krantz, and others, 2005; Ator and Denver, 2012). Groundwater also carries nitrate directly to estuaries where sediments are coarse-grained with low organic matter (Speiran, 1996), similar to the setting in fig. 30-1a. 


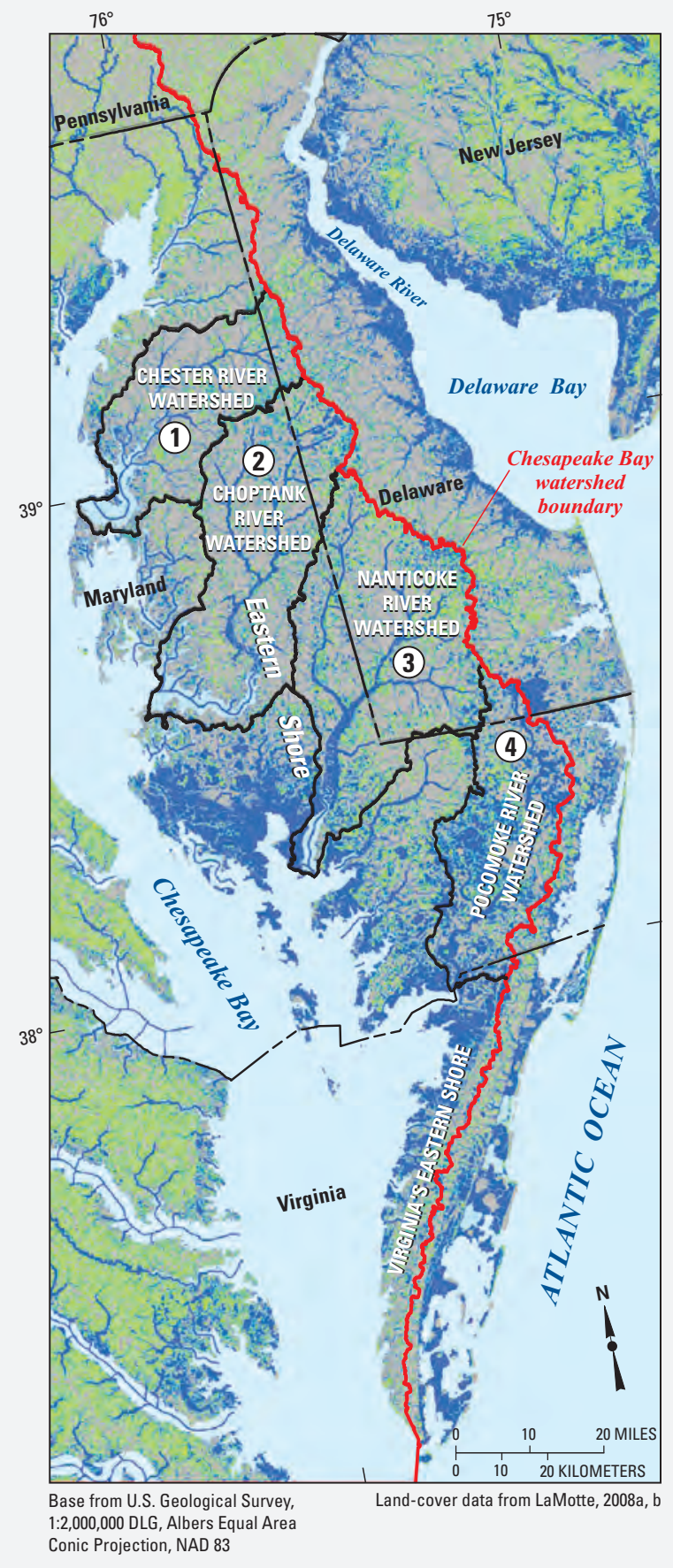

EXPLANATION

Selected natural features

Streams or wetlands

Forest

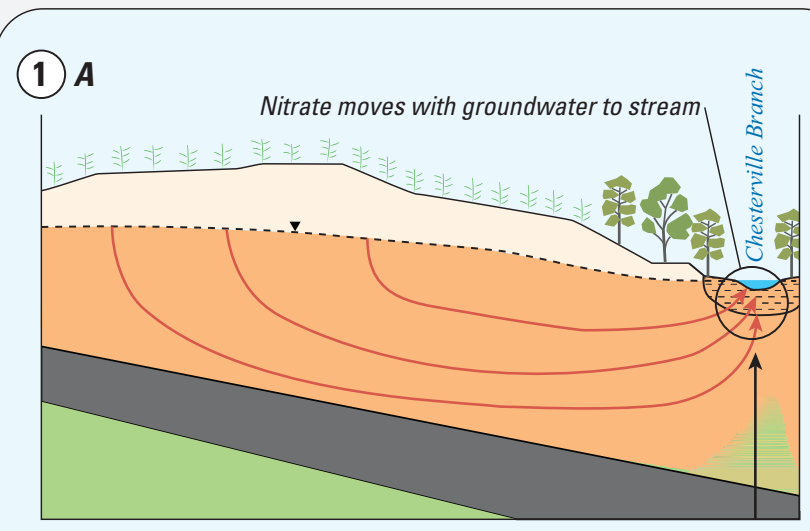

The surficial aquifer in the Chesterville Branch watershed contains dissolved oxygen in most areas, and groundwater carries nitrate at relatively high concentrations to Chesterville Branch.

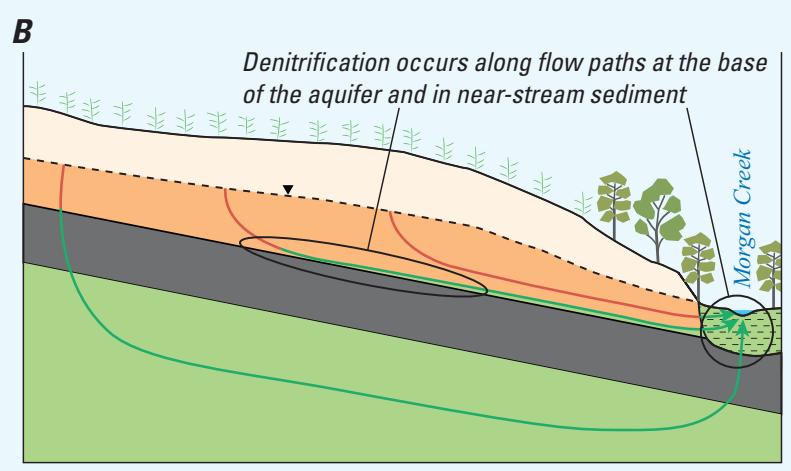

C

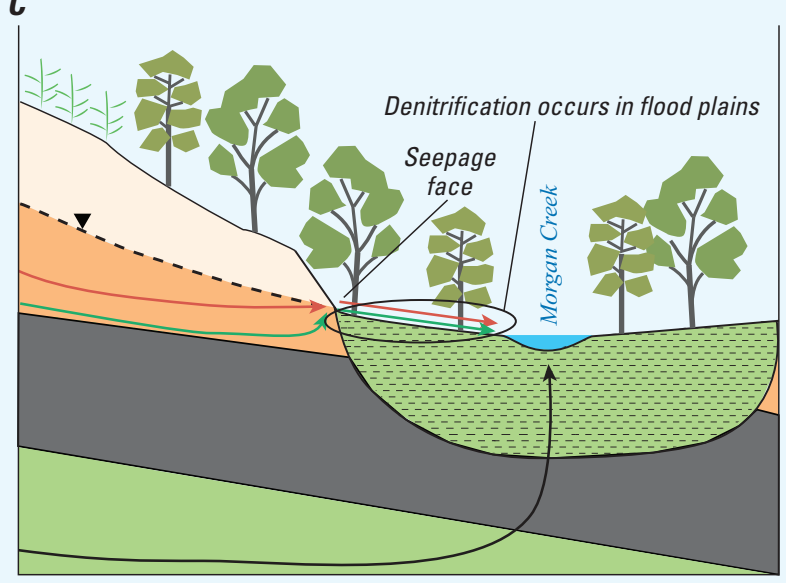

In the Morgan Creek watershed, nitrate is lost from groundwater to denitrification near the base of the aquifer and in near-stream sediments, and as groundwater that discharges at a seepage face flows across the flood plain.

Böhlke and Denver, 1995; Bachman and others, 2002; Ator, Denver, and Brayton, 2005; Hancock and Brayton, 2006; Domagalski and others, 2008; Denver and others, 2010.

Figure 30. Idealized summary of hydrologic conditions and the potential for denitrification in groundwater in various hydrogeologic settings on the Eastern Shore. Denitrification has been observed in many different settings on the Eastern Shore, but the effectiveness of denitrification in limiting nitrogen transport through groundwater to streams varies substantially with varying hydrogeologic conditions. 
(2) $A$

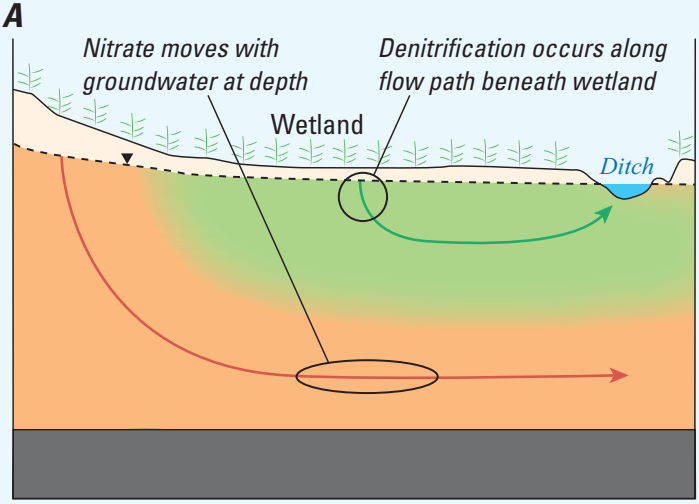

B

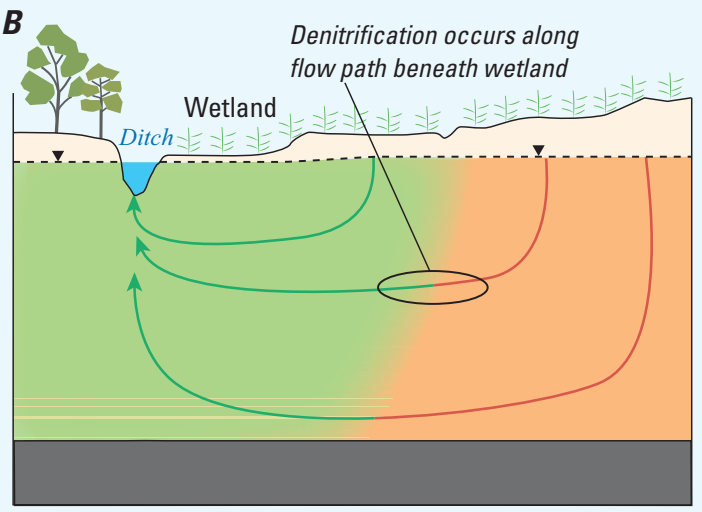

Nitrate is lost in anoxic groundwater beneath depressional wetlands in the upper part of the Choptank River watershed. The lateral and vertical extent of anoxic groundwater may be limited, however, and groundwater containing dissolved oxygen and nitrate may pass beneath these wetlands to discharge areas in streams. (Denver and others, 2014.)

(3)

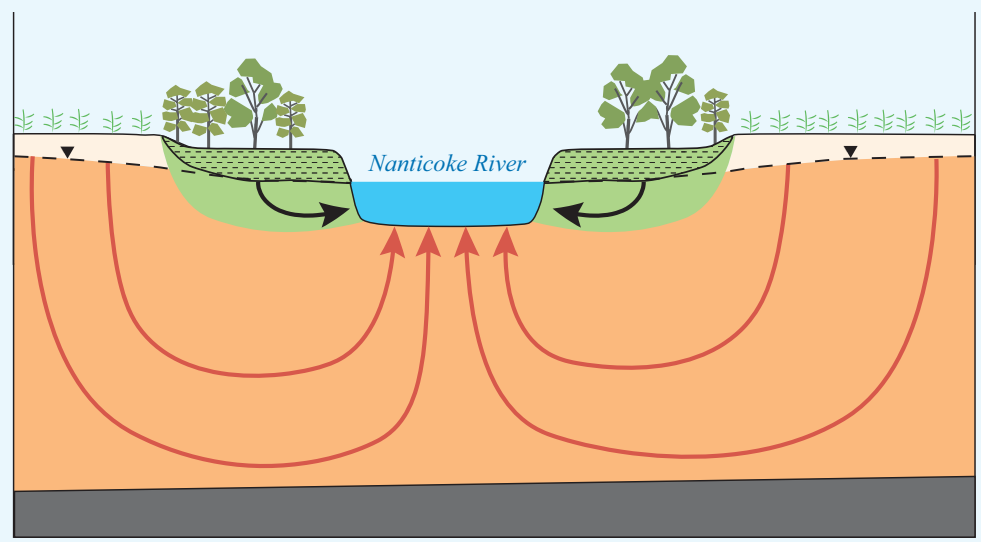

\section{EXPLANATION}

\section{Hydrogeologic units}

$\square$ Aquifer with oxic groundwater

Aquifer with anoxic groundwater

Confining unit

- - Water table

\section{Groundwater flow paths}

$\checkmark$ Containing nitrate

$\longrightarrow$ Nitrate removed by denitrification

$\longrightarrow$ Likely never contained nitrate

Streams and rivers of the Nanticoke watershed have been channelized to lower the water

table. Because of this, much of the groundwater containing nitrate discharges directly through the sandy streambed and bypasses anoxic flood-plain sediments. (Clune and Denver, 2012.)

(4)

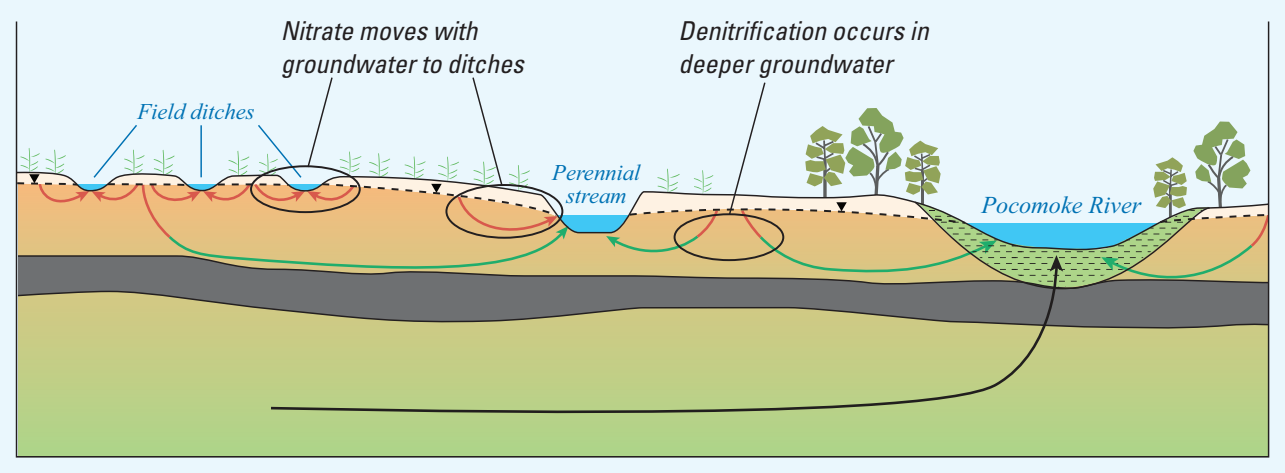

Short flow paths often carry nitrate through shallow groundwater to ditches in farm fields in the Pocomoke River watershed; denitrification occurs along longer flow paths contributing to larger streams and the river. (Phillips and Donnelly, 2003; Ator, Denver, and Brayton, 2005; Denver and others, 2010; McCoy, Sigrist, and others, 2010.)

Figure 30. Idealized summary of hydrologic conditions and the potential for denitrification in groundwater in various hydrogeologic settings on the Eastern Shore. Denitrification has been observed in many different settings on the Eastern Shore, but the effectiveness of denitrification in limiting nitrogen transport through groundwater to streams varies substantially with varying hydrogeologic conditions.-Continued 


\section{Phosphorus}

Phosphorus moves from source areas on the land surface to streams on the Eastern Shore primarily in overland runoff. Phosphorus is much less soluble in water than nitrate, particularly where dissolved oxygen is abundant. Phosphorus compounds therefore generally remain bound to soils and sediment in particulate form rather than moving to groundwater in dissolved form, although phosphorus may dissolve in groundwater in anoxic areas. Consequently, phosphorus transport to streams occurs primarily during high-flow periods following precipitation when erosion and overland runoff may mobilize and carry soil, sediment, and attached phosphorus to streams (figs. 27, 29) (Denver and others, 2004; Ator, Denver, and Brayton, 2005). Unlike nitrate concentrations, phosphorus and sediment concentrations are often greatest in streams during high-flow periods (fig. 29). Although shallow slopes and permeable soils and sediments typical of much of the Eastern Shore suggest soil erosion and related phosphorus transport to streams may be relatively minor, the transport of phosphorus from upland sources to streams is greater in the Coastal Plain than in other areas of the Chesapeake Bay watershed (Ator and others, 2011). Phosphorus from manure applications in excess of crop needs has been accumulating in Eastern Shore soils for decades (fig. 26), and such soils may carry greater phosphorus to streams during runoff periods than in the past and be less likely to sequester newly applied phosphorus (Heckrath and others, 1995; Staver and Brinsfield, 2001). Agricultural management practices (such as no-till cropping) that increase phosphorus at the land surface may also increase dissolved phosphorus in runoff (Staver and Brinsfield, 1995).

Phosphorus is much less soluble in water than nitrate, and consequently moves from source areas on the landscape to streams and tidal waters on the Eastern Shore primarily in solid (particulate) form over the land surface rather than through groundwater. 


\section{Chapter 4. Nitrogen and Phosphorus in Groundwater and Surface Waters of the Eastern Shore}

\author{
How high are concentrations of nitrogen and phosphorus \\ in groundwater, streams, and estuaries on the Eastern Shore?
}

On the Eastern Shore, nitrogen is common in groundwater and surface waters and phosphorus is common in surface waters at concentrations that are well above natural levels, and are among the highest in the Nation. Differing concentrations in different areas are attributable to varying inputs from agriculture and other sources, as well as hydrogeologic, soil, and other natural conditions that affect the fate and movement of nitrogen compounds through the subsurface and phosphorus over the land surface.

\section{Regional Groundwater Quality}

Nitrate occurs in groundwater in many areas of the unconfined surficial aquifer on the Eastern Shore, typically at concentrations far greater than would be expected under natural conditions (see sidebar: "Natural Water Quality"), and often at concentrations high enough to affect the suitability of the water for human consumption (Hamilton and others, 1993; Ferrari, 2001; Debrewer and others, 2007) (fig. 31). The presence of nitrate at concentrations indicative of human contamination has been reported in different parts of the aquifer since at least the early 1970s (fig. 31) (Cushing and others, 1973; Bachman, 1984; Denver, 1986) (see sidebar: "Eastern Shore Water Quality in a National Context”) (figs. 32, 33). In the early 2000s, nitrate concentrations at various depths in the surficial aquifer on the Delmarva Peninsula had a median concentration above 5 milligrams per liter (mg/L as N), even in relatively deep parts of the aquifer commonly used for public supplies (Ferrari, 2001; Debrewer and others, 2007). More time is generally required for groundwater to move to greater depths, and the occurrence of nitrate from human sources at similar concentrations at various depths within the aquifer reflects the long history of agricultural nitrogen application on the Eastern Shore (figs. 25, 26). Concentrations in about one-third of samples from shallow groundwater in agricultural areas and from deeper groundwater commonly used for domestic supply in the early 2000 s exceeded $10 \mathrm{mg} / \mathrm{L}$, the Federal drinking-water standard (Maximum Contaminant Level) for nitrate in public water supplies (Debrewer and others, 2007). Consumption of water containing nitrate at concentrations greater than $10 \mathrm{mg} / \mathrm{L}$ can cause health problems, particularly in infants (U.S. Environmental Protection Agency, 2004), and prolonged consumption of nitrate at even lower concentrations in drinking water may be related to the development of certain types of cancer (Aschebrook-Kilfoy and others, 2012).

Nitrate occurs in groundwater in many areas of the Eastern

Shore at concentrations well above what might be expected under natural conditions, and concentrations that may affect the suitability of groundwater for drinking water are not uncommon.

Nitrate concentrations in groundwater in different areas of the Eastern Shore are related to the distribution of sources and natural soil and geochemical conditions affecting nitrate fate and transport (Debrewer and others, 2007; Ator, 2008). Concentrations are generally highest near agricultural areas, although horizontal groundwater flow may carry nitrate to

\section{Natural Water Quality}

Natural water (water that has not been chemically influenced by human activities) in aquifers and streams on the Eastern Shore is typically dilute and acidic with few dissolved chemicals. Rainfall on the peninsula is generally acidic with very low concentrations of dissolved chemicals. The surficial aquifer on the Eastern Shore (particularly in the central part of the peninsula) is composed of quartz-rich sediments that are relatively insoluble and therefore include few natural minerals that may dissolve in infiltrating rainwater (Denver, 1989; Knobel and others, 1998; Ator and others, 2000). Natural groundwater in the aquifer is therefore typically similarly dilute and acidic, as is water in local streams, which receive the majority of their flow from groundwater discharge. Younger sediments common in coastal areas are generally finer-textured and contain a greater variety of minerals and more organic matter, however, and natural groundwater and streams in such areas often contain a greater variety of dissolved compounds contributed from these materials (Tesoriero and others, 2004; Ator, 2008). Nitrate from natural sources such as leaf litter and other vegetation rarely exceeds $0.4 \mathrm{mg} / \mathrm{L}$ in groundwater or $0.6 \mathrm{mg} / \mathrm{L}$ in streams on the Eastern Shore (Hamilton and others, 1993; Clark and others, 2000). 
groundwater beneath other land uses, as well (fig. 27). Nitrate concentrations are significantly higher in oxic groundwater where any nitrate that is formed in the soil zone and transported to groundwater is persistent (see Chapter 3). These conditions generally occur in areas with good soil drainage and permeable soils and sandy aquifer sediments that promote oxic conditions, such as in much of the central core of the Delmarva Peninsula (fig. 31). In contrast, concentrations of nitrate are typically low in areas with anoxic aquifer conditions where denitrification is common (see Chapter 3), such as those that generally occur in wetlands and in low-lying areas along Chesapeake Bay and its tidal tributaries (Bachman and others, 1998; Shedlock and others, 1999; Debrewer and others, 2007).

Nitrate concentrations have increased in groundwater in parts of the surficial aquifer in recent decades. Nitrate concentrations in oxic groundwater on the Delmarva Peninsula increased by an average of about $2 \mathrm{mg} / \mathrm{L}$ between the late 1980 s and the early 2000s at depths in the surficial aquifer typically used for domestic supplies (fig. 34), although no such changes occurred during that period in shallower groundwater (Debrewer and others, 2007, 2008). The increase in nitrate concentrations in groundwater over that period is likely a result of increasing nitrate leaching to groundwater from increasing fertilizer and poultry manure nitrogen applications to the landscape during previous decades when groundwater sampled during 1988 and 2001 moved from the land surface to the water table (figs. 25, 26).

Concentrations of ammonia, organic nitrogen, and phosphorus compounds in groundwater on the Eastern Shore are generally much lower than concentrations of nitrate and generally do not exceed $0.2 \mathrm{mg} / \mathrm{L}$ (Debrewer and others, 2007). Although concentrations of these compounds may be elevated in poorly drained anoxic areas (Debrewer and others, 2008), ammonium concentrations are still typically relatively low compared to nitrate concentrations in groundwater because ammonium is preferentially adsorbed on certain clay minerals that are present in the soil (Denver, 1986). Once these ions are fixed in the soil, they are not likely to be removed. Phosphorus also is present in fertilizers, manure, and human sewage, but is fixed by silicate clays and oxides of iron, aluminum, and manganese in the soil zone and aquifer sediments and generally not dissolved in groundwater (Denver, 1986).

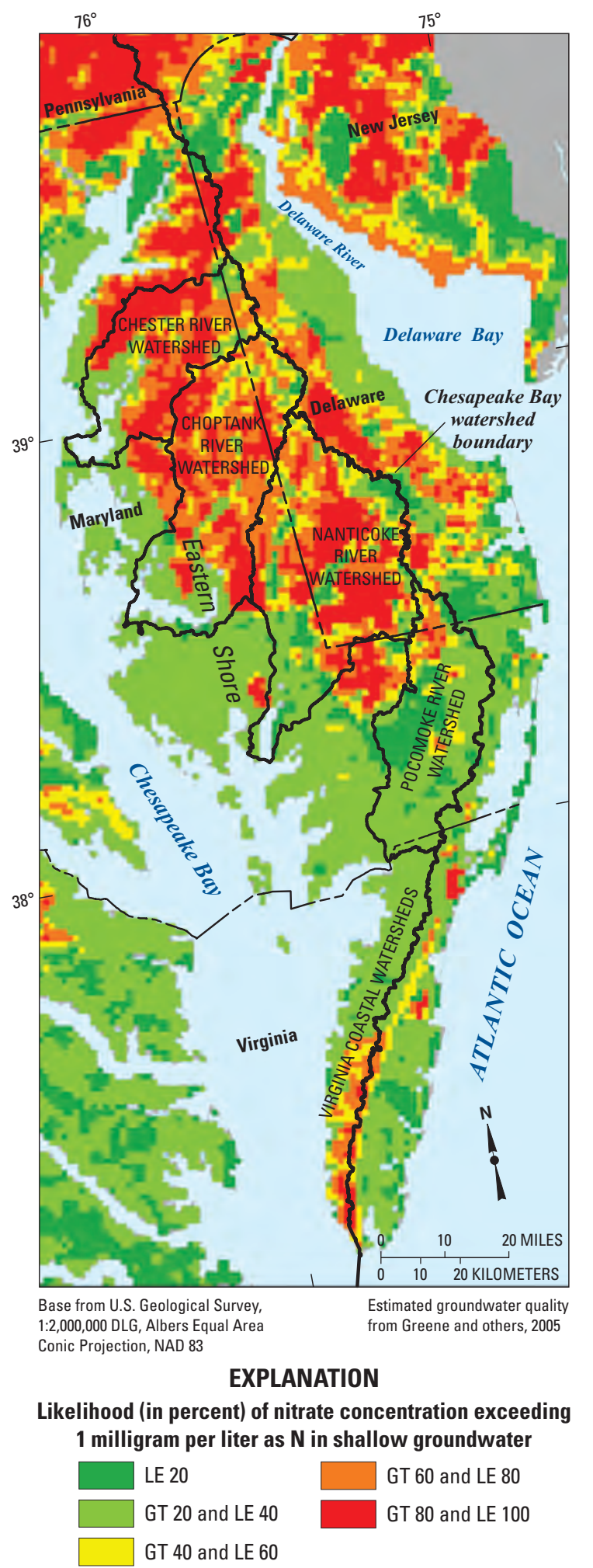

Figure 31. Estimated probability of nitrate concentrations in shallow groundwater exceeding 1 milligram per liter as $\mathrm{N}$ in areas of the Delmarva Peninsula. Nitrate concentrations often exceed estimated natural levels (less than 0.4 milligrams per liter) in groundwater in many areas of the Eastern Shore, particularly in the central core of the Delmarva Peninsula. (GT = greater than; $\mathrm{LE}=$ less than or equal to.) 


\section{Eastern Shore Water Quality in a National Context}

Nutrient concentrations in streams and shallow groundwater in parts of the Eastern Shore are among the highest in the Nation (Denver and others, 2004). Nitrogen and phosphorus sources are abundant on the Eastern Shore, and hydrologic, geologic, and soil conditions in many areas are particularly suitable for the persistence of these compounds in the environment and their movement to streams and shallow groundwater (see Chapter 3). Consequently, nitrate concentrations in groundwater (fig. 32) and nitrogen and phosphorus concentrations in selected streams (fig. 33) in agricultural areas are among the highest observed in similar settings across the United States.

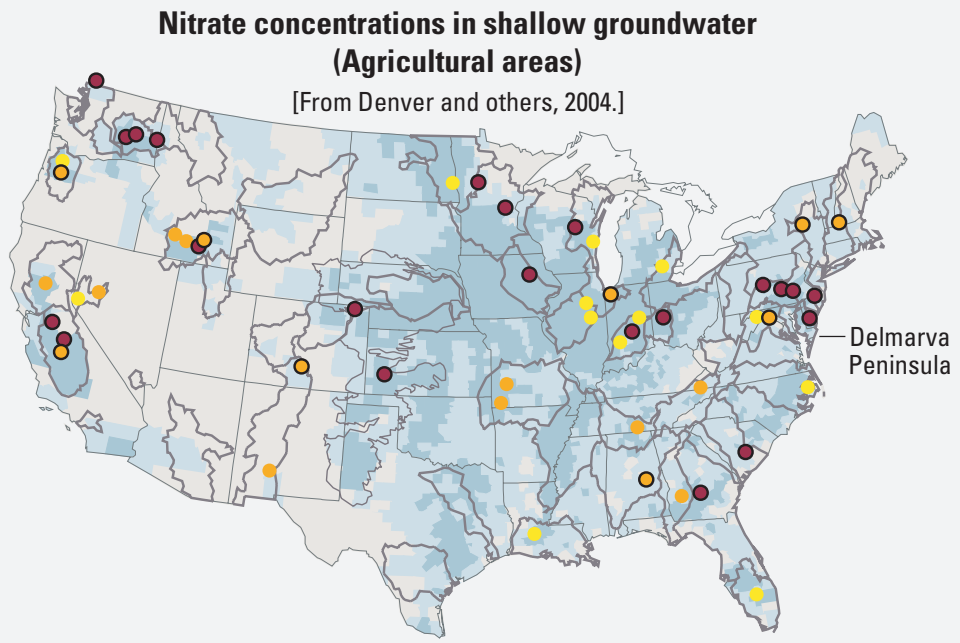

Median concentration of nitrate, in milligrams per liter as $\mathbf{N}$. Each circle represents a groundwater study.

- Highest (greater than 5 milligrams per liter as N)

- Medium (0.4 to 5 milligrams per liter as N)

Lowest (less than 0.4 milligrams per liter as N)

\section{Background concentration}

O Bold outline indicates median values greater than background concentration (2 milligrams per liter as $\mathrm{N}$ )

Average annual total nitrogen input, in pounds per acre, by county, for 1995-98. Inputs are from fertilizer, manure, and the atmosphere.

$\square$ Greater than 25

$\square 6$ to 25

$\square$ Less than 6

Figure 32. Summary of nitrate concentrations in shallow groundwater in selected agricultural areas of the United States. Nitrate concentrations in shallow groundwater underlying agricultural areas on the Eastern Shore are among the highest observed in agricultural areas of the Nation.

Total nitrogen in streams, 1993-2001

Total phosphorus in streams, 1993-2001 (Agricultural areas) [From Denver and others, 2004.] (Agricultural areas)
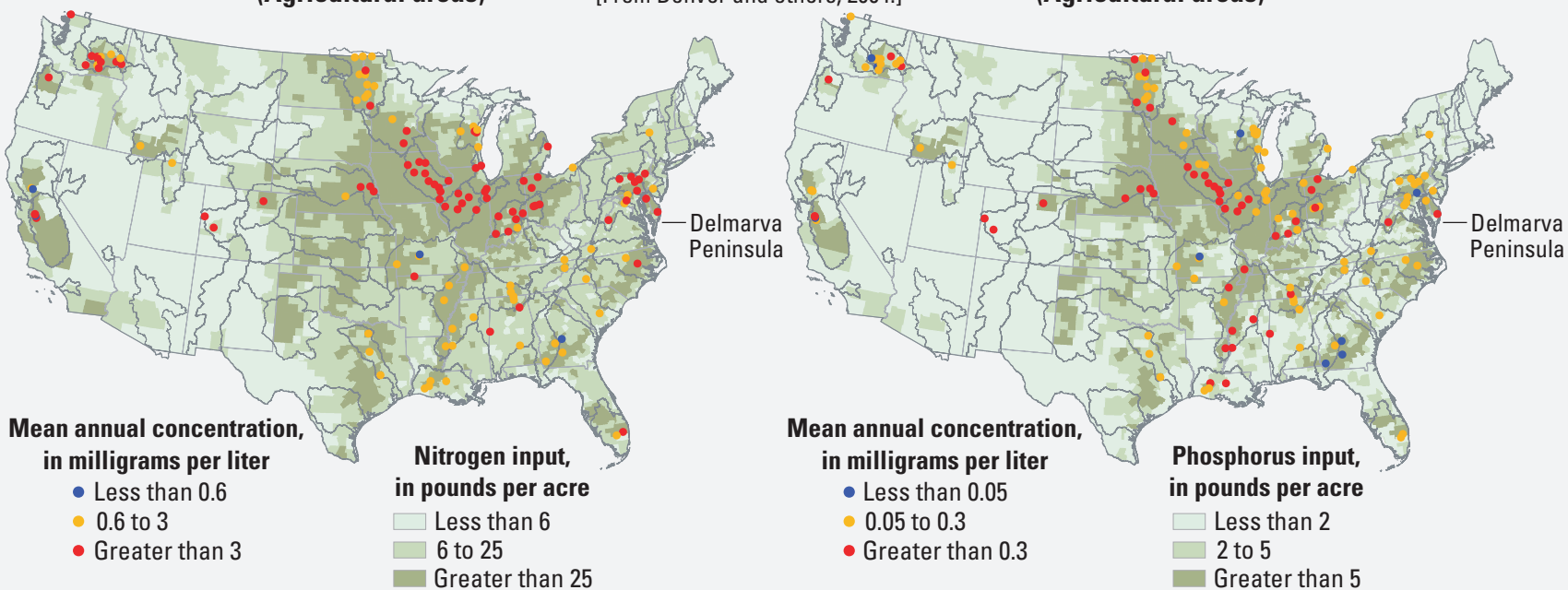

Figure 33. Summary of nitrogen and phosphorus concentrations in selected streams draining primarily agricultural areas of the United States. Nitrogen and phosphorus concentrations in streams in agricultural areas on the Eastern Shore are among the highest in the Nation. 


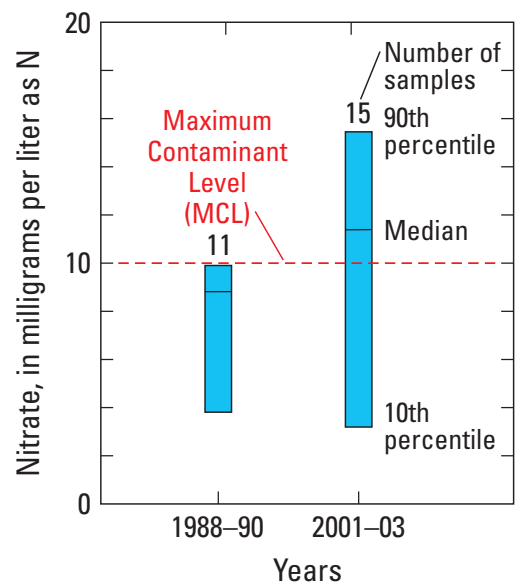

[Modified from Debrewer and others, 2007 See also Debrewer and others, 2008.]

Figure 34. Summary of nitrate concentrations in the surficial aquifer on the Delmarva Peninsula during 1988-90 and 2001-03. Nitrate concentrations increased between the late 1980 s and early 2000s at depths typically used for domestic supply.
Nitrate concentrations in Eastern Shore streams reflect a combination of the abundance of agricultural and other nitrogen sources, hydrogeologic conditions that often promote nitrate formation and transport from the land surface, and the resulting elevated nitrate typical of shallow groundwater. The vast majority (over 90 percent) of headwater streams on the Delmarva Peninsula contained nitrate at concentrations greater than natural levels (see sidebar: "Natural Water Quality") during base flow in the winter and spring of 2000, and about half contained nitrate exceeding $3 \mathrm{mg} / \mathrm{L}$ (fig. 35) (Denver and others, 2004; Ator and Denver, 2012). Similar base-flow nitrate concentrations were observed in Eastern Shore streams during the early 1990s (Bachman and Phillips, 1996). Nitrate concentrations in larger streams draining primarily agricultural areas are also typically greater than would be expected under natural conditions (see sidebar: "Eastern Shore Water Quality in a National Context"), but lower than in headwater streams draining exclusively agricultural areas (fig. 36) (Ator, Denver, and Brayton, 2005; Langland and others, 2013). Nitrate

Concentrations of nitrate in Eastern Shore streams are generally lower than concentrations in contributing groundwater, but concentrations of phosphorus and other nitrogen compounds are often higher in streams. Both nitrogen and phosphorus occur in Eastern Shore streams at concentrations that may adversely affect aquatic ecosystems.

\section{Regional Surface-Water Quality}

Nitrate concentrations in freshwater streams on the Eastern Shore are typically lower than in nearby groundwater (fig. 35), although concentrations of phosphorus and other nitrogen compounds (ammonium and organic nitrogen) are generally higher in streams than in groundwater (Shedlock and others, 1999; Denver and others, 2004; Ator, Denver, and Brayton, 2005). During base-flow conditions, streams are a mixture of groundwater contributed from multiple flow paths reflecting a variety of land uses and human impacts over time (figs. 21, 27). The highest nitrate concentrations entering streams with groundwater are therefore often diluted by mixing with water from other flow paths that have lower nitrate concentrations. These flow paths may have originated beneath forests where nitrogen was not applied, contain water that comes from older flow paths where nitrate concentrations are low, or come from parts of the aquifer system that are anoxic. Biological processes also may consume nitrate in streams, particularly during the growing season. Because phosphorus and other nitrogen compounds are typically less soluble than nitrate and most commonly transported with sediment, however, they often occur at much higher concentrations in streams than in groundwater, particularly during high-flow periods when streamflow is dominated by overland runoff (fig. 29) (Shedlock and others, 1999; Denver and others, 2004; Ator, Denver, and Brayton, 2005).

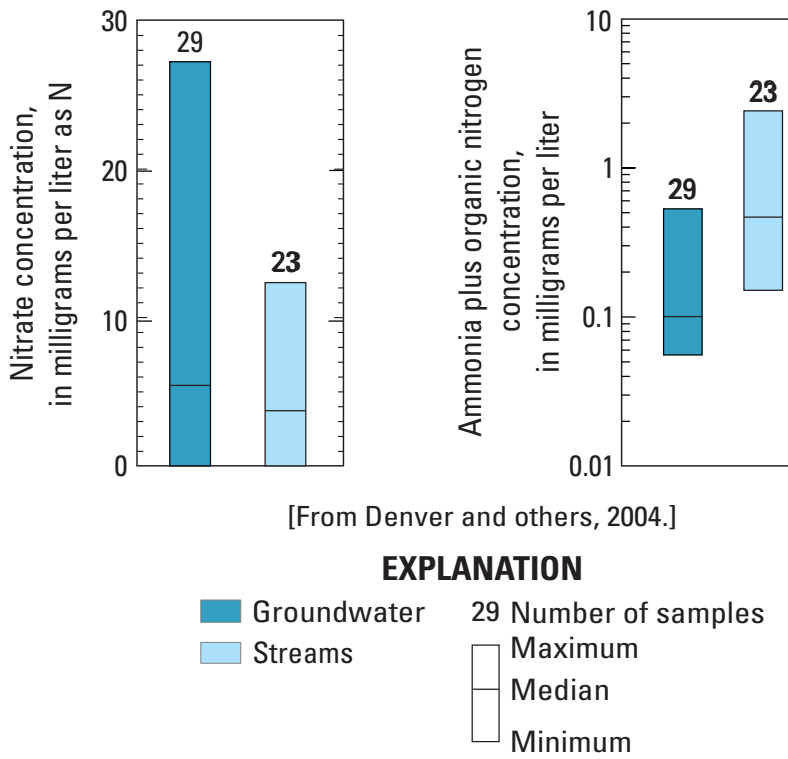

Figure 35. Concentrations of nitrogen compounds in streams and shallow groundwater on the Delmarva Peninsula, 2000-01. Nitrate concentrations are often higher in shallow groundwater than in receiving streams, but ammonia plus organic nitrogen concentrations are generally higher in streams. 

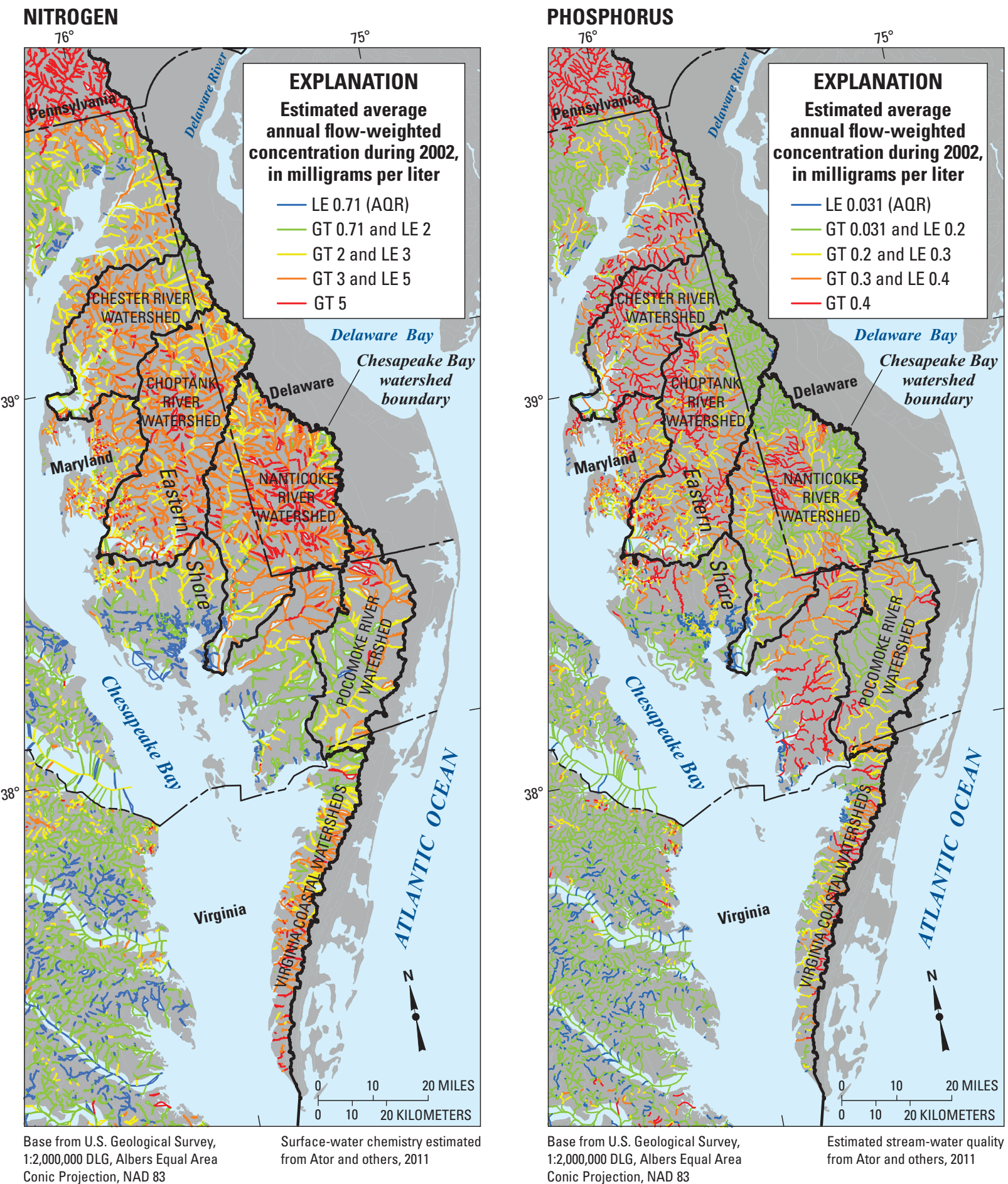

Figure 36. Estimated average-annual flow-weighted concentrations of nitrogen and phosphorus in Eastern Shore streams. Concentrations of nitrogen and phosphorus in streams of the Eastern Shore generally exceed natural levels. (AQR is the water-quality criteria recommended to protect aquatic organisms [U.S. Environmental Protection Agency, 2000]. GT = greater than; $\mathrm{LE}=$ less than or equal to.) 
concentrations in Eastern Shore streams often vary seasonally; concentrations are generally greatest in the winter months when groundwater discharge is greatest and uptake by aquatic plants is minimal, and lowest in the late summer when such conditions are reversed (fig. 37) (Denver and others, 2004; Ator, Denver, and Brayton, 2005).

Phosphorus, ammonia, and organic nitrogen are generally present along with nitrate in Eastern Shore streams, however, like in groundwater, typically at much lower concentrations. Phosphorus concentrations in streams draining undeveloped watersheds are generally less than $0.02 \mathrm{mg} / \mathrm{L}$ and rarely exceed $0.1 \mathrm{mg} / \mathrm{L}$ (Clark and others, 2000). Concentrations of phosphorus in Eastern Shore streams during base-flow conditions are generally well below $0.1 \mathrm{mg} / \mathrm{L}$, but can be much higher (as high as 3 or $4 \mathrm{mg} / \mathrm{L}$ ) during high-flow periods (fig. 29), or in poorly drained areas with abundant organic matter and low dissolved oxygen (fig. 36) (Denver and others, 2004; Ator, Denver, and Brayton, 2005) (see sidebar: "Eastern Shore Water Quality in a National Context"). Concentrations of ammonia plus organic nitrogen in Eastern Shore streams during base-flow conditions are typically well below $1.0 \mathrm{mg} / \mathrm{L}$ (fig. 35), but — like phosphorus - can increase substantially during high-flow periods (Clark and others, 2000; Ator, Denver, and Brayton, 2005).

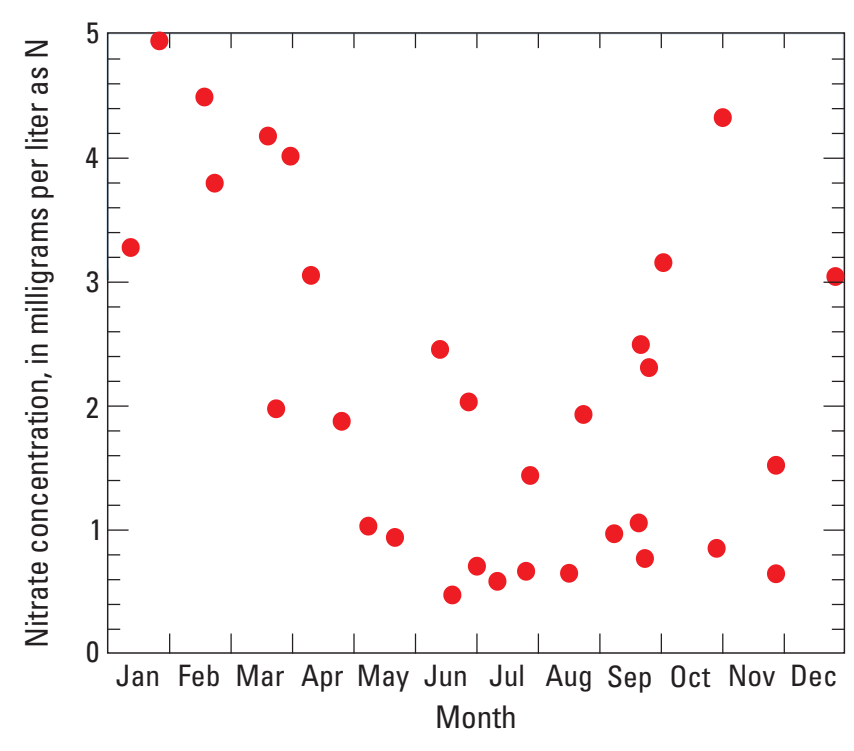

[From Denver and others, 2004.]

Figure 37. Seasonal variability in nitrate concentrations in the Pocomoke River, 1999-2001. Nitrate concentrations reflect greater shallow groundwater discharge and lesser biotic activity in the cooler months and reversed conditions during the warmer months.
Nitrogen and phosphorus in stream water contribute to excessive algal growth and other ecological deterioration of freshwater streams on much of the Eastern Shore.

Concentrations of nitrogen greater than $0.71 \mathrm{mg} / \mathrm{L}$ and (or) phosphorus greater than $0.031 \mathrm{mg} / \mathrm{L}$ in streams of the eastern Coastal Plain may cause excessive plant growth and other conditions detrimental to aquatic organisms, and these concentrations have been recommended as criteria to protect aquatic communities (U.S. Environmental Protection Agency, 2000). Nitrate concentrations, alone, commonly exceed $0.71 \mathrm{mg} / \mathrm{L}$ in Eastern Shore streams (fig. 35), and phosphorus concentrations greater than $0.031 \mathrm{mg} / \mathrm{L}$ are not unusual (fig. 36) (Clark and others, 2000; Ator, Denver, and Brayton, 2005). Although the growth and decay of algae and aquatic plants and resulting oxygen depletion depend on the availability of light and other habitat conditions as well as water quality, such conditions in Eastern Shore streams are apparently generally not limited by the availability of nutrients. Overall, the structure and composition of communities of benthic aquatic organisms in Eastern Shore streams are typically fair, poor, or very poor (fig. 38) (Chesapeake Bay Program, 2012).

Nutrient concentrations in Eastern Shore streams are increasing, particularly where nonpoint sources are important and groundwater is a dominant pathway for nutrient transport. Nitrate concentrations in the Choptank and Nanticoke Rivers have increased consistently since the mid-1960s (fig. 39), primarily due to increasing nitrate concentrations in groundwater discharge (fig. 34), the predominant source of water and nitrate to those rivers (Hirsch and others, 2010; Robert Hirsch, USGS, written commun., 2013). Similarly, total nitrogen and phosphorus have increased since the mid-1980s in the Choptank River, in spite of the restoration of streamside buffers to forest in much of the Choptank watershed since the 1990s (Sutton and others, 2010) (fig. 39). Suspended-sediment yields in the Choptank River have generally increased since 2001, but on average, have decreased since 1985 (Moyer and others, 2012). Phosphorus transport to streams occurs primarily in particulate form attached to sediment, and increasing phosphorus concentrations during a period of decreasing sediment concentrations (possibly due to forested buffer restoration) suggests that dissolved phosphorus transport may be increasing and (or) that average concentrations of particulate phosphorus on sediment particles moving to the Choptank River are increasing. 


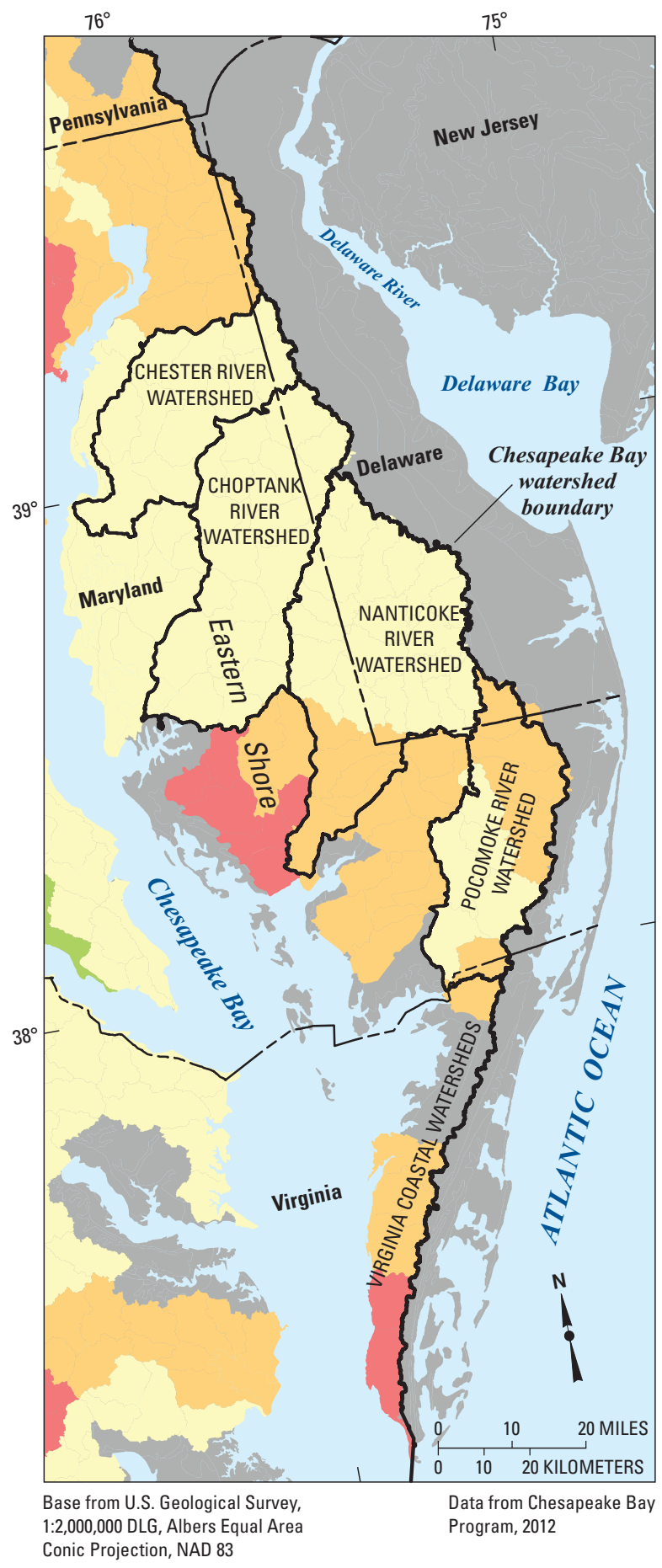

\section{EXPLANATION}

Health of freshwater ecosystems, 2000-10,

based on communities of benthic aquatic organisms

\begin{tabular}{ll}
\hline & Good \\
\hline & Fair \\
\hline & Poor \\
$\square$ & Very poor
\end{tabular}

Figure 38. Ecological conditions in Eastern Shore tributaries to the Chesapeake Bay assessed by sampling communities of benthic aquatic organisms. Ecological conditions in Eastern Shore streams are generally fair, poor, or very poor. 


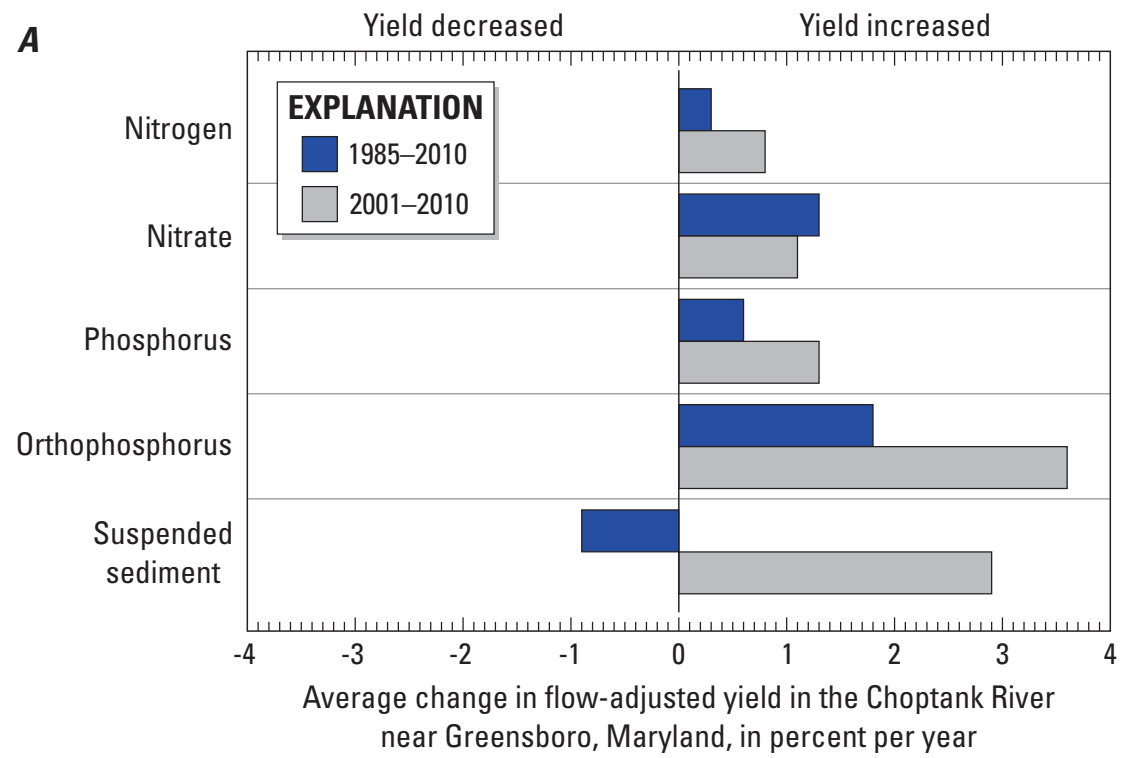

[From Moyer and others, 2012.]

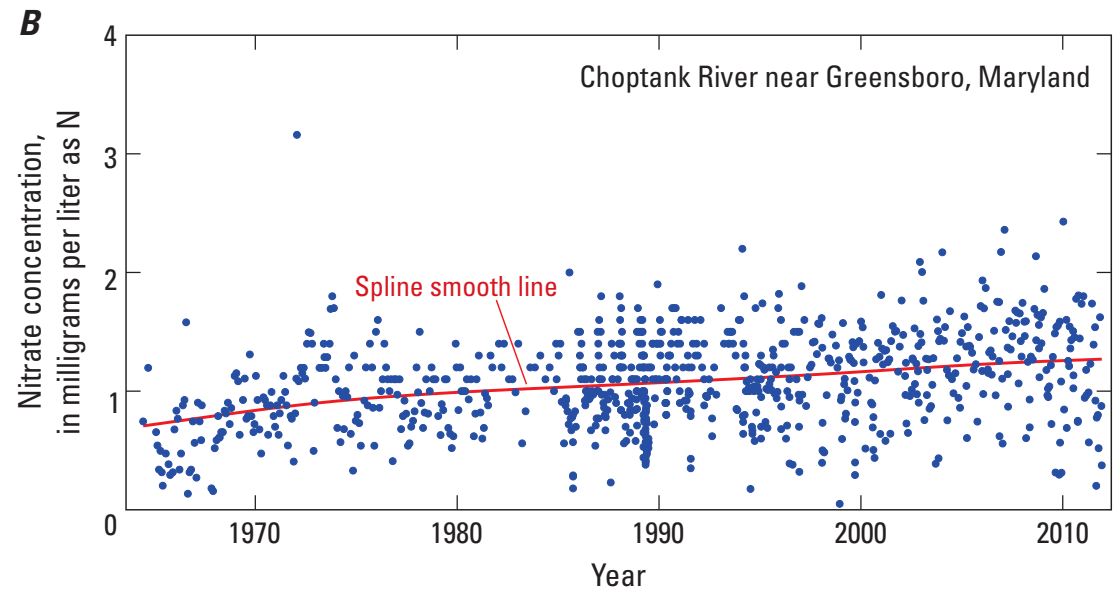

[From U.S. Geological Survey, 2014.]

Figure 39. Trends in $(A)$ average nutrient yields during 1985 through 2010 and 2001 through 2010, and $(B)$ nitrate concentrations from the mid-1960s through 2013 in the Choptank River near Greensboro, Maryland. Nutrient concentrations have generally increased in the river over recent decades. 


\section{Water Quality in Tidal Estuaries}

Degraded ecological conditions in tidal reaches of major streams draining the Eastern Shore reflect high inputs of nitrogen and phosphorus from contributing watersheds. Eutrophic conditions in Chesapeake Bay may be controlled by either nitrogen or phosphorus inputs during different seasons (Prasad and others, 2010), and include excessive algal growth and related decreases in dissolved oxygen, submerged aquatic vegetation, and habitat for benthic organisms (Bricker and others, 2007; McCoy, Spotts, and others, 2010; U.S. Environmental Protection Agency, 2011a). Water quality and benthic habitat in Eastern Shore sub-estuaries to Chesapeake Bay are often similarly fair or poor (Fisher and others, 2006; U.S. Environmental Protection Agency, 2008b); eutrophic conditions (particularly chlorophyll- $a$ levels), for example, were high or moderately high in tidal reaches of the Chester and Choptank Rivers and in Tangier and Pocomoke Sounds during 2004, and worsened in the Chester and Choptank River estuaries between 1999 and 2004 (Bricker and others, 2007). Dissolved oxygen levels in deeper waters in the Choptank River estuary decreased between 1984 and 2004, and approached minimum water-quality standards during wet years (Fisher and others, 2006).

\section{Nitrogen and Phosphorus in Major Eastern Shore Watersheds}

Locally variable land use, associated nutrient inputs, and hydrogeologic, soil, and other natural conditions contribute to similarly variable nitrogen and phosphorus concentrations in streams and groundwater in different parts of the Eastern Shore and resulting differences in nutrient contributions to Chesapeake Bay. Local differences in natural drainage and other hydrologic conditions are reflected in differing rural landscapes among major Eastern Shore watersheds within the broader agricultural setting (fig. 40). These differences are related to variations in natural conditions (see Chapter 2) and contribute to variable inputs and transport of nitrogen and phosphorus to tidal waters (fig. 41). Some areas have similar landscape characteristics (such as, for example, forested riparian wetlands) but different subsurface conditions that affect the potential for denitrification in groundwater (see sidebar: "Nitrate Removal Through Denitrification, and Limitations Caused by Local Hydrogeology"). Phosphorus transport from areas receiving similar inputs also varies substantially with variable soil conditions that affect phosphorus retention on the landscape or movement to streams. Local studies in different areas of the Eastern Shore (see following sections) illustrate the importance of these differences to predominant pathways of nutrient transport in different areas, and results from these studies can be extrapolated to understanding nutrient transport in other parts of the Eastern Shore and the wider Coastal Plain region where relevant physical conditions are similar. 
Well-drained soils, incised stream channels, and extensive areas of agricultural production in parts of the Chester River watershed lead to high concentrations of nitrate in groundwater transported to streams and overland transport of phosphorus.

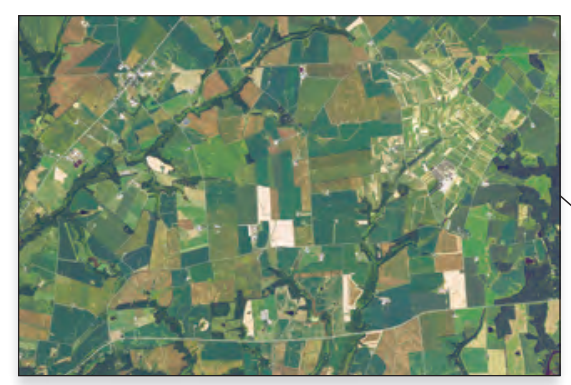

Low topographic relief, channelized streams, extensive agriculture over sandy soils, and a thick permeable surficial aquifer limit overland runoff and phosphorus transport, but lead to high concentrations of nitrate in groundwater and streams in parts of the Nanticoke River watershed.

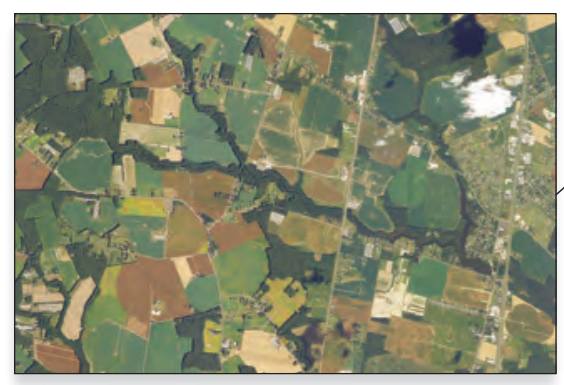

The Eastern Shore of Virginia is narrow and dissected by numerous tidal creeks and inlets. Groundwater discharge and overland runoff directly to tidal waters are the major pathways for nutrient transport. Poor drainage and extensive wetlands limit nutrient transport in the north, but well-drained soils and sandy aquifer sediments directly adjacent to tidal waters promote nutrient transport to surface water further south.

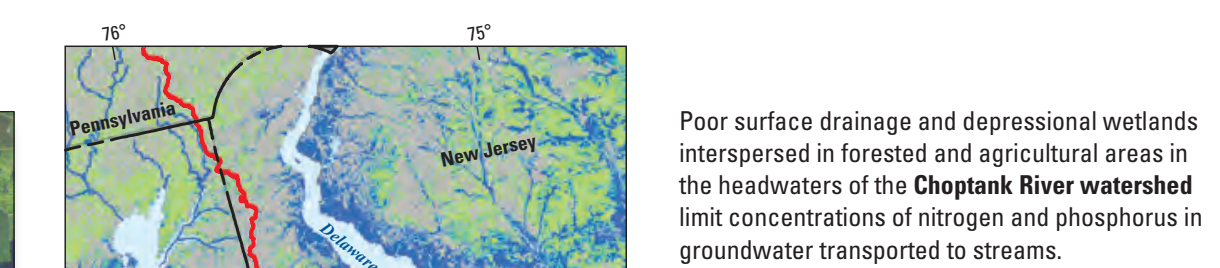
groundwater transported to streams.

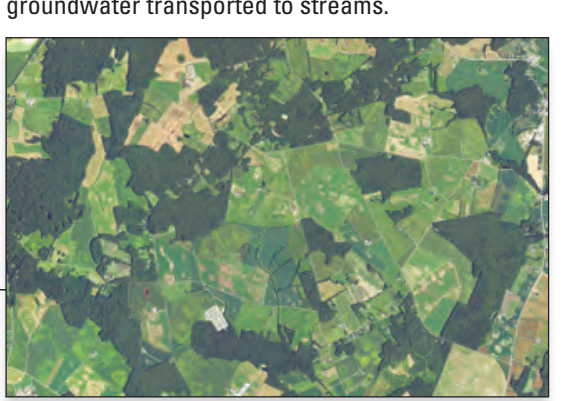

The very flat landscape of the Pocomoke River watershed requires extensive ditching in fields and channelization of streams to lower the water table and allow for crop production. The field ditches are generally not buffered and provide short flow paths for nutrient movement into streams.
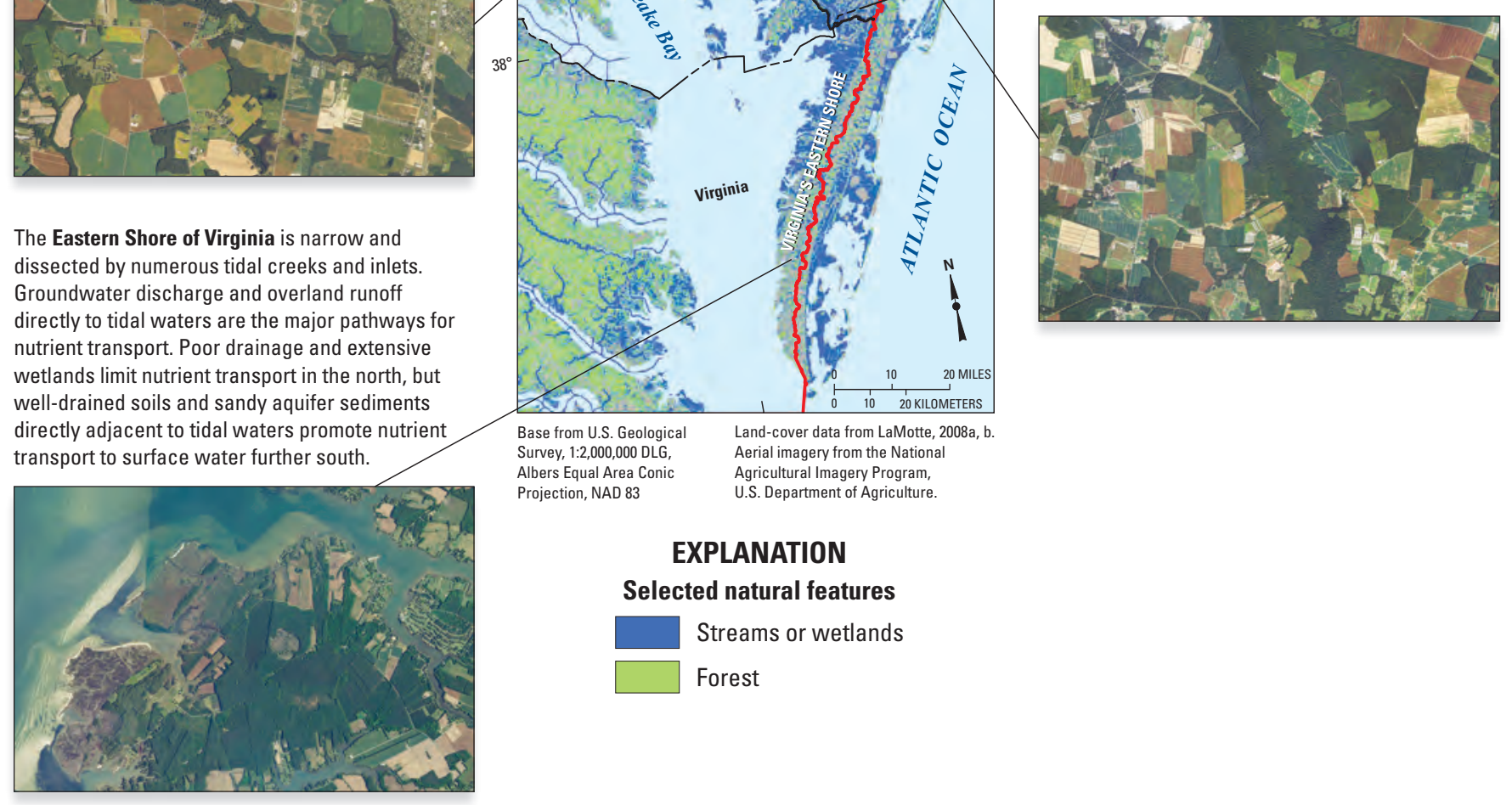

\section{EXPLANATION}

\section{Selected natural features}

Streams or wetlands

Forest

Figure 40. A summary of selected landscapes on the Eastern Shore. Variable landscapes and hydrogeology affect the inputs and transport of nutrients among major Eastern Shore watersheds. 

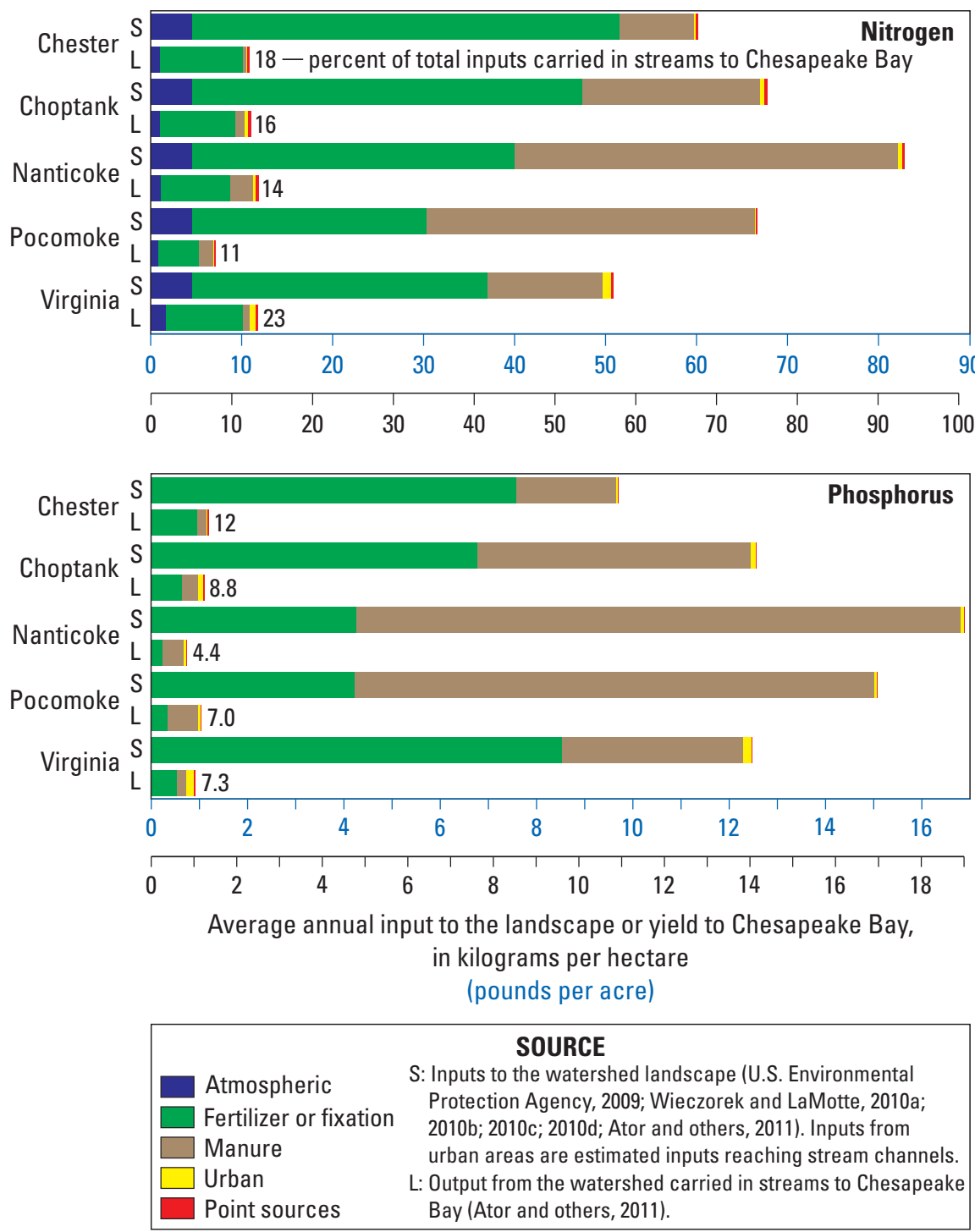

Figure 41. Estimated nitrogen and phosphorus inputs to the landscape from various sources, 2002, and average annual outputs in streamflow to Chesapeake Bay. Nutrient outputs vary among major Eastern Shore watersheds and generally represent less than 25 percent of inputs. 


\section{Chester River Watershed}

Natural soil and hydrogeologic conditions promote the movement of nutrients from the land surface to surface waters in much of the Chester River watershed, although a thin surficial aquifer limits nitrogen movement through groundwater in some areas. The watershed includes $760 \mathrm{~km}^{2}$ of the upper Eastern Shore (fig. 42). Agriculture, mostly the production of corn, soybeans and small grains, covers about 60 percent of the watershed and contributes 87 percent of the nitrogen load and 95 percent of the phosphorus load from the watershed to Chesapeake Bay. Agriculture in the watershed is typically underlain by well-drained sandy soils (see Chapter 2) that promote the formation of nitrate and its movement to shallow groundwater (see Chapter 3) (fig. 30-1). Concentrations of nitrate in these areas are consequently often between 10 and $20 \mathrm{mg} / \mathrm{L}$ in groundwater (Domagalski and others, 2008; Denver and others, 2010) and greater than $3 \mathrm{mg} / \mathrm{L}$ in streams (Böhlke and Denver, 1995; Bachman and others, 2002; Ator, Denver, and Brayton, 2005; Domagalski and others, 2008). Nitrate is the major form of nitrogen in streams, as would be expected if most nitrogen transport to streams occurs through groundwater (Domagalski and others, 2008). Phosphorus concentrations in groundwater are generally less than $0.1 \mathrm{mg} / \mathrm{L}$ (Bachman and others, 2002) but can be much higher in streams during periods of overland flow following storms when surface transport of nutrients occurs (fig. 29) (Ator, Denver, and Brayton, 2005).

Nitrate concentrations in streams in the Chester River watershed are typically lower than in contributing groundwater, and reflect variability in land use and the thickness of the surficial aquifer. The general lack of human inputs in the forested eastern headwaters is reflected in surface-water nitrate concentrations that rarely exceed $1 \mathrm{mg} / \mathrm{L}$ (fig. 36) and average nitrogen and phosphorus yields that are among the lowest in the watershed (fig. 42). In agricultural areas, however, the thickness of the surficial aquifer varies and is a primary control on the movement of nitrate from groundwater to local streams (Böhlke and Denver, 1995; Bachman and others, 2002; Ator, Denver, and Brayton, 2005; Denver and others, 2010) (fig. 30-1) (see sidebar: "Nitrate Removal Through Denitrification, and Limitations Caused by Local Hydrogeology"). The surficial aquifer is relatively thick (up to $30 \mathrm{~m}$ ) beneath Chesterville Branch, a tributary in the northern part of the watershed, and much of the nitrate in groundwater discharges with minimal losses to streams (fig. 30-1a). Nitrate concentrations in Chesterville Branch during base flow have been measured between 8 and $10 \mathrm{mg} / \mathrm{L}$. In watersheds of the Morgan Creek and the Corsica River tributaries, however, some streams have incised completely through the surficial aquifer into an underlying fine-grained deposit, and much of the discharging groundwater is forced through shallow anoxic

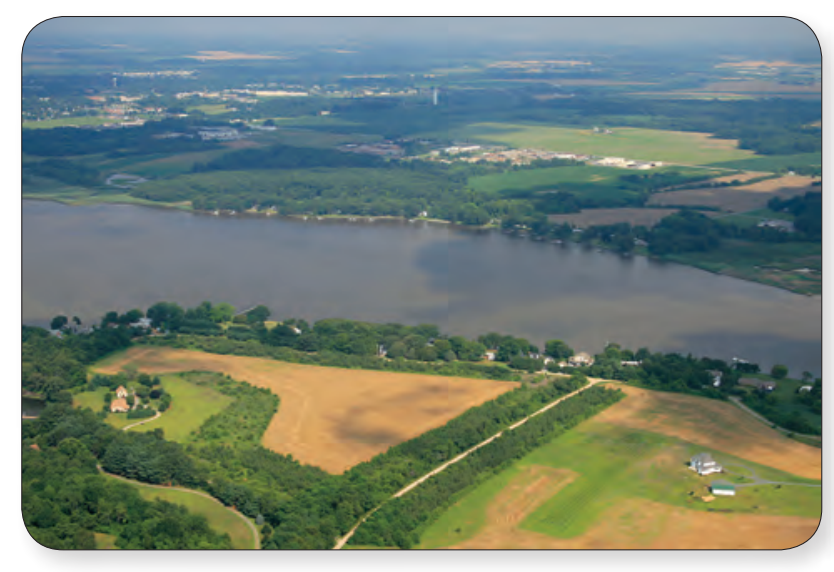

Chester River just east of Chestertown, Maryland.

Photograph by Jane Thomas, Integration and Application Network, University of Maryland Center for Environmental Science (ian.umces.edu/imagelibrary/).

sediments (fig. 30-1b) or through seeps to the flood plain, where denitrification can occur (Hancock and Brayton, 2006) (see Chapter 3) (fig. 30-1c). Nitrate concentrations in these streams during base flow are consequently generally lower than in Chesterville Branch, but still around $5 \mathrm{mg} / \mathrm{L}$ (Böhlke and Denver, 1995; Bachman and others, 2002; Ator, Denver, and Brayton, 2005; McCarthy and Capel, 2009; Denver and others, 2010).

Phosphorous is transported to streams in the Chester River watershed from agricultural areas primarily with water and sediment during periods of overland runoff. Concentrations of phosphorus in streams are generally higher than in groundwater, and during runoff periods can approach $1 \mathrm{mg} / \mathrm{L}$ (fig. 29). Phosphorus yields from the Chester River watershed are highest where the potential for runoff carrying phosphorus-laden sediment from agricultural fields is greatest, such as where land-surface slopes are steepest.

Natural conditions in the Chester River watershed promote the relatively efficient transport of nutrients from application areas to Chesapeake Bay. On average, nutrient yields from the Chester River watershed to Chesapeake Bay are very similar to or greater than those from the Choptank and Nanticoke Rivers, in spite of lower average inputs (fig. 41). Particularly efficient nitrogen transport is facilitated by the generally thick and permeable surficial aquifer; phosphorus transport within the watershed is facilitated by average land slope and relief in the Chester River watershed that is generally greater than in watersheds further south (see Chapter 2). Reductions of 190 tons of nitrogen and 10 tons of phosphorus per year will be required to meet the TMDL for the Chesapeake Bay in this watershed (fig. 13). The majority of these reductions will be required from agriculture, the largest local source of nutrients (fig. 41). 


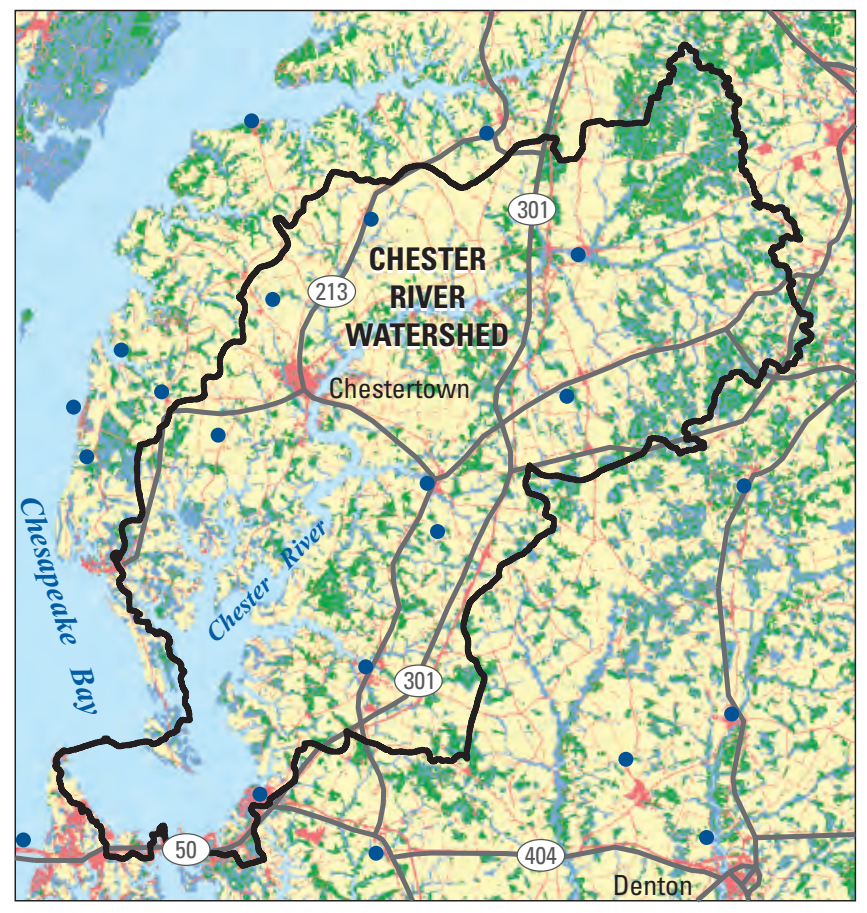

Land cover from LaMotte, 2008a, b

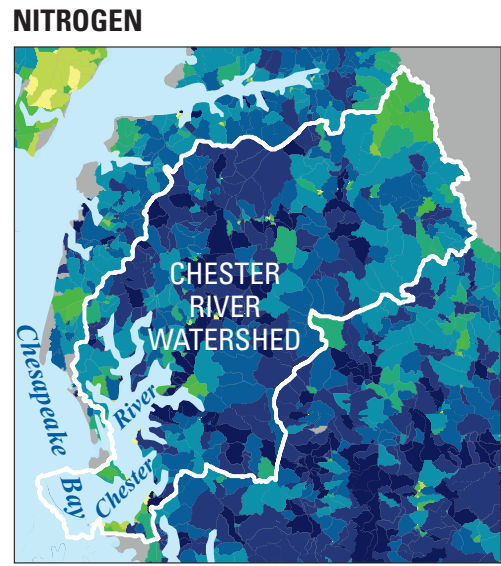

Estimated nutrient yields from Ator and others, 2011

\begin{tabular}{|c|c|}
\hline \multicolumn{2}{|c|}{$\begin{array}{l}\text { EXPLANATION } \\
\text { Land cover }\end{array}$} \\
\hline \multirow{2}{*}{$\begin{array}{l}\text { Agriculture } \\
\text { Urban }\end{array}$} & Wetland \\
\hline & Open water \\
\hline Forest & $\begin{array}{l}\text { - Nutrient point } \\
\text { source }\end{array}$ \\
\hline \multicolumn{2}{|c|}{$\begin{array}{c}\text { Estimated annual yield to local streams, } \\
\text { in kilograms per hectare } \\
\text { (pounds per acre) }\end{array}$} \\
\hline NITROGEN & $\underline{\text { PHOSPHORUS }}$ \\
\hline LE 2 (1.8) & LE $0.05(0.04)$ \\
\hline GT 2 and LE 3 (2.7) & GT 0.05 and LE 0.1 (0.09) \\
\hline GT 3 and LE 4 (3.6) & GT 0.1 and LE $0.2(0.18)$ \\
\hline GT 4 and LE 5 (4.4) & GT 0.2 and LE $0.3(0.27)$ \\
\hline GT 5 and LE 7 (6.2) & GT 0.3 and LE $0.5(0.44)$ \\
\hline GT 7 and LE 10 (8.8) & GT 0.5 and LE $0.8(0.71)$ \\
\hline GT 10 and LE 14 (12) & GT 0.8 and LE $1(0.88)$ \\
\hline GT 14 and LE 17 (15) & GT 1 and LE 1.5 (1.3) \\
\hline GT 17 and LE $22(20)$ & GT 1.5 and LE 2 (1.8) \\
\hline GT 22 & GT 2 \\
\hline
\end{tabular}

\section{PHOSPHORUS}

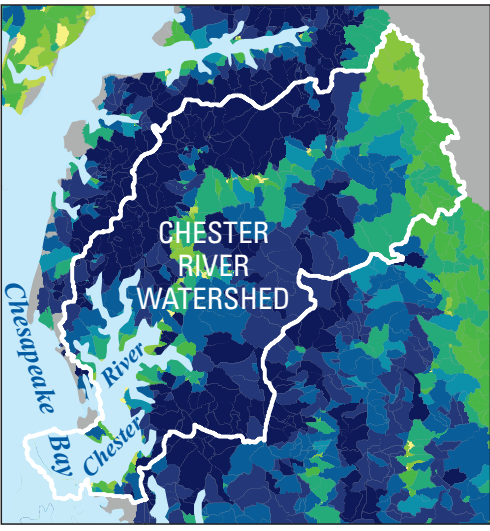

Estimated nutrient yields from Ator and others, 2011

Figure 42. The Chester River watershed. The watershed is located on the upper Eastern Shore and is primarily agricultural. Nutrient yields from the land surface to streams are generally lower in the forested eastern headwaters than in the remainder of the watershed, which is predominantly agricultural. (GT = greater than; $\mathrm{LE}=$ less than or equal to.) 


\section{Choptank River Watershed}

Anoxic groundwater around current and former wetlands limits nitrogen movement through groundwater in parts of the Choptank River watershed, although natural conditions promote nitrate transport through groundwater to streams in other areas. Agriculture covers about 60 percent of the land in the Choptank River watershed (fig. 43) and contributes more than 80 percent of the load of nitrogen and phosphorus from the watershed to Chesapeake Bay (fig. 41). A large part of the headwaters, however (particularly in the east above Greensboro, Maryland), includes poorly drained uplands (see Chapter 2) where agriculture is interspersed with large tracts of forested wetlands. Streams in this area are generally low gradient and channelized, and artificial ditches lower the water table beneath depressional wetlands in agricultural fields. In other areas of the watershed (such as around the Tuckahoe Creek tributary to the west), however, better drainage and greater stream incision are common, ditching is less prevalent, and agricultural tracts are generally larger. Nitrate in oxic groundwater commonly exceeds $20 \mathrm{mg} / \mathrm{L}$ beneath agricultural fields with well-drained soils, but is less than $1 \mathrm{mg} / \mathrm{L}$ in poorly drained forested areas with minimal nitrogen inputs and around current and former wetlands where groundwater is typically anoxic (Staver, 2010; Denver and others, 2014) (see sidebar: "Nitrate Removal Through Denitrification, and Limitations Caused by Local Hydrogeology").

As in most areas of the Eastern Shore, groundwater provides the majority of nitrate to streams in the Choptank River watershed (Knee and Jordan, 2013), and concentrations in individual streams reflect concentrations in local contributing groundwater. Nitrate concentrations in small streams in predominantly poorly drained and forested sub-watersheds are generally less than $0.5 \mathrm{mg} / \mathrm{L}$ (McCarty and others, 2008; Denver and others, 2014). In agricultural areas, concentrations during base flow are generally higher in well-drained parts of the Tuckahoe Creek watershed (often 4 to $5 \mathrm{mg} / \mathrm{L}$ ) than in more poorly drained areas of the Choptank River watershed farther east (about $2 \mathrm{mg} / \mathrm{L}$ ) (McCarty and others, 2008). Nitrate concentrations in the Choptank River have increased consistently since the 1960s, primarily due to increasing nitrate concentrations in groundwater discharging to the river (fig. 39) (Fisher and others, 2006; Hirsch and others, 2010).

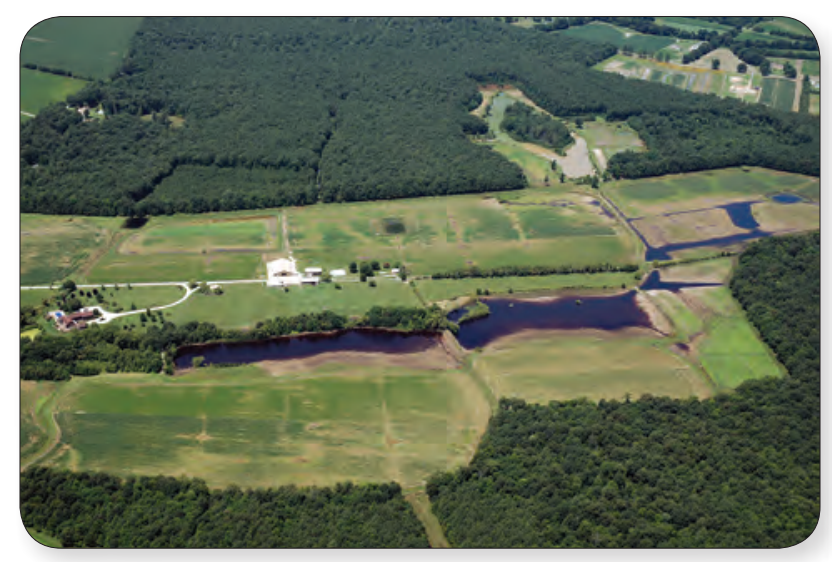

Choptank River watershed flooded farm field, June 2006. Photograph by Jane Thomas, Integration and Application Network, University of Maryland Center for Environmental Science (ian.umces.edu/imagelibrary/).

Phosphorus concentrations in the Choptank River generally range from less than $0.01 \mathrm{mg} / \mathrm{L}$ during base flow to about $0.2 \mathrm{mg} / \mathrm{L}$ during higher flow (Sprague and others, 2000).

Concentrations of phosphorus have increased over time in the river, in spite of decreasing concentrations of suspended sediment (Fisher and others, 2006; Langland and others, 2013). Increasing concentrations of phosphorus in the river during a period of decreasing sediment concentrations suggests increasing dissolved phosphorus transport in the watershed or increasing average phosphorus content on suspended sediment. These conditions may be related to increasing phosphorus saturation in watershed soils and resulting decreasing soil retention of applied phosphorus (Ator and others, 2011).

Hydrogeologic and landscape conditions that are more conducive to anoxic conditions and denitrification (particularly in the headwaters) promote slightly less efficient nutrient transport from the Choptank River watershed than from the Chester River watershed. In spite of more intensive inputs of fertilizer and manure in the Choptank River watershed, average yields of nitrogen and phosphorus to Chesapeake Bay are very similar to those from the Chester River watershed (fig. 41). Reductions of approximately 105 tons of nitrogen and 23 tons of phosphorus per year will be required in the Choptank River watershed to meet the 2010 TMDL for the Chesapeake Bay (fig. 13). 


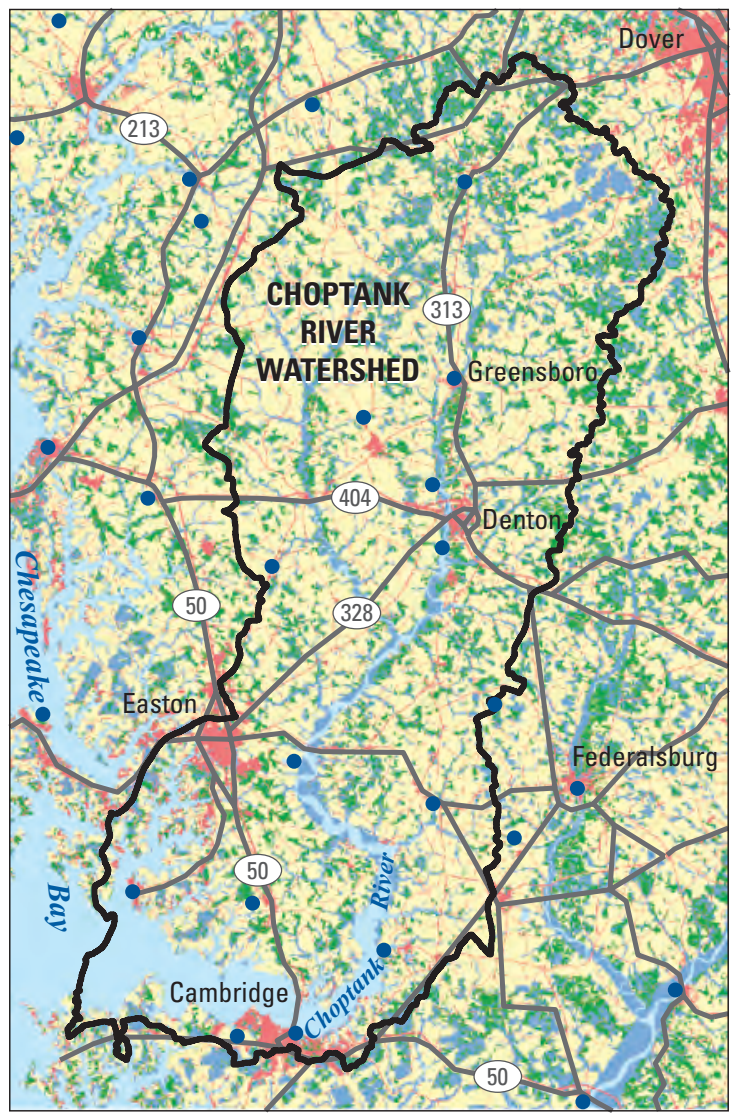

Land cover from LaMotte, 2008a, b

\section{NITROGEN}

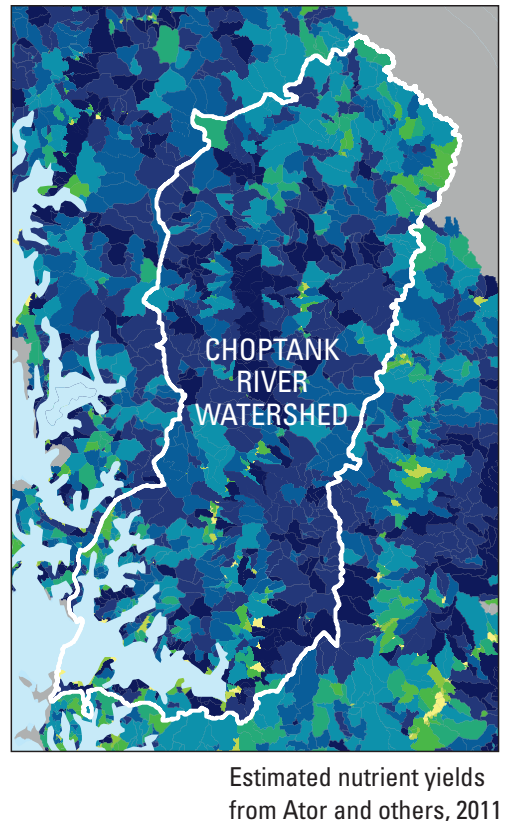

\begin{tabular}{|c|c|}
\hline \multicolumn{2}{|c|}{$\begin{array}{l}\text { EXPLANATION } \\
\text { Land cover }\end{array}$} \\
\hline \multirow{2}{*}{$\begin{array}{l}\text { Agriculture } \\
\text { Urban }\end{array}$} & Wetland \\
\hline & Open water \\
\hline Forest & $\begin{array}{l}\text { - Nutrient point } \\
\text { source }\end{array}$ \\
\hline \multicolumn{2}{|c|}{$\begin{array}{c}\text { Estimated annual yield to local streams, } \\
\text { in kilograms per hectare } \\
\text { (pounds per acre) }\end{array}$} \\
\hline NITROGEN & PHOSPHORUS \\
\hline LE $2(1.8)$ & LE $0.05(0.04)$ \\
\hline GT 2 and LE 3 (2.7) & GT 0.05 and LE 0.1 (0.09) \\
\hline GT 3 and LE 4 (3.6) & GT 0.1 and LE 0.2 (0.18) \\
\hline GT 4 and LE 5 (4.4) & GT 0.2 and LE $0.3(0.27)$ \\
\hline GT 5 and LE 7 (6.2) & GT 0.3 and LE $0.5(0.44)$ \\
\hline GT 7 and LE 10 (8.8) & GT 0.5 and LE 0.8 (0.71) \\
\hline GT 10 and LE 14 (12) & GT 0.8 and LE 1 (0.88) \\
\hline GT 14 and LE 17 (15) & GT 1 and LE 1.5 (1.3) \\
\hline GT 17 and LE $22(20)$ & GT 1.5 and LE 2 (1.8) \\
\hline GT 22 & GT 2 \\
\hline
\end{tabular}

\section{PHOSPHORUS}

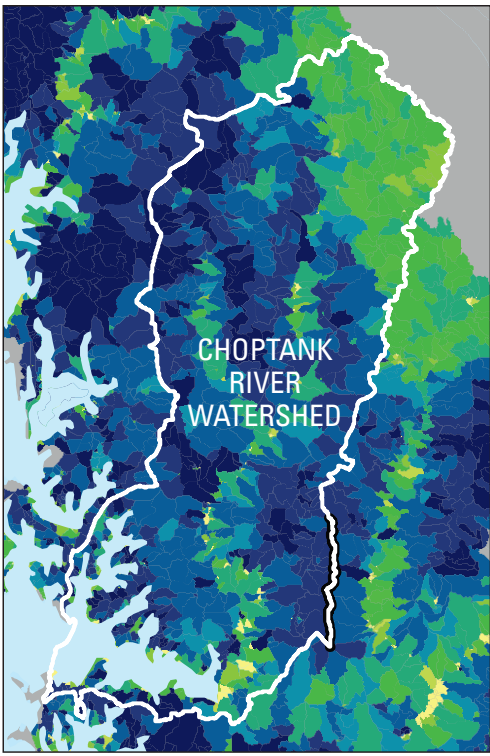

Estimated nutrient yields from Ator and others, 2011

Figure 43. The Choptank River watershed. The watershed covers 1,800 square kilometers from its headwaters in Kent County, Delaware to its tidal estuary near Cambridge, Maryland. As in the Chester River watershed, nutrient yields are generally lower in the forested eastern headwaters where wetlands are common than in the remainder of the watershed where agriculture and welldrained soils are more common. ( $G T=$ greater than; $L E=$ less than or equal to.) 


\section{Nanticoke River Watershed}

Water quality in the Nanticoke River watershed reflects locally variable land use and hydrologic conditions. Most of the Nanticoke River watershed is in the low-relief upland characteristic of much of the central Delmarva Peninsula (see Chapter 2). Incision of nontidal streams is generally limited but channelization and artificial ditches are common (fig. 40). Where successful in areas of well-drained sandy soils and a thick (up to $30 \mathrm{~m}$ ) surficial aquifer, artificial drainage has lowered the water table in support of agriculture, which covers about 41 percent of the Nanticoke River watershed (fig. 44), and includes intensive poultry production. Forest and wetlands cover much of the remainder of the watershed, particularly in the eastern headwaters where drainage has been less successful. Agriculture contributes 85 percent of the nitrogen load and 92 percent of the phosphorus load from the watershed to Chesapeake Bay (fig. 41). In agricultural areas, nitrate concentrations in groundwater commonly exceed $10 \mathrm{mg} / \mathrm{L}$ (Clune and Denver, 2012) and concentrations in headwater streams and ditches are similarly elevated (Andres and others, 2007; Clune and Denver, 2012). Nitrate concentrations in forested areas rarely exceed $1 \mathrm{mg} / \mathrm{L}$. Average yields of nitrogen and phosphorus are greatest in the central part of the watershed where agriculture is concentrated, and relatively low in the poorly drained forested headwaters and in riparian wetlands near major stream channels (fig. 44). In the main stem of the Nanticoke River, nitrate concentrations range from around 3 to $5 \mathrm{mg} / \mathrm{L}$ and phosphorus concentrations range from less than 0.1 during base flow to about $0.5 \mathrm{mg} / \mathrm{L}$ during storms (Andres and others, 2007). As in the Choptank River, nitrate concentrations in the Nanticoke River have increased consistently since the 1960s due to increases in nitrate in discharging groundwater (Robert Hirsch, USGS, written commun., 2013).

Although nutrient applications in the Nanticoke River watershed (particularly manure) are greater, on average, than in the Chester, Choptank, or Pocomoke River watersheds,

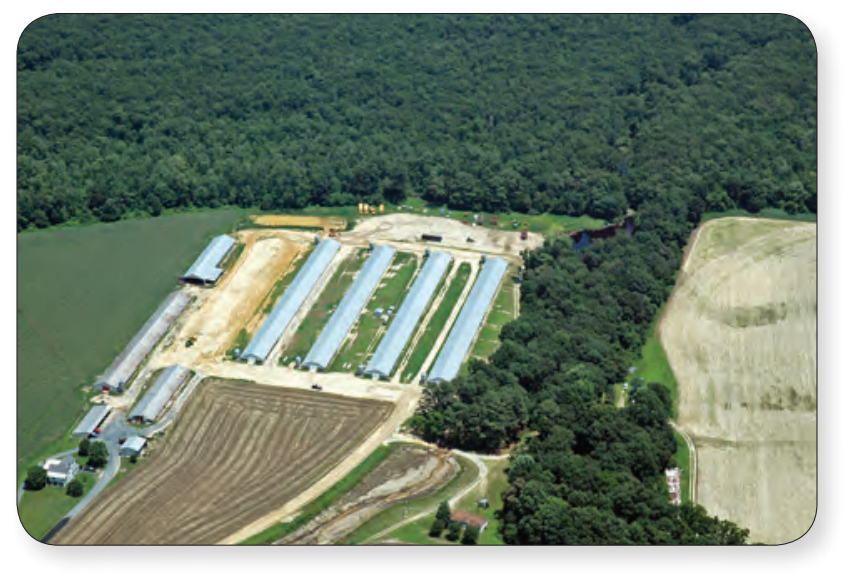

Poultry farming in the Nanticoke River watershed.

Photograph by Jane Thomas, Integration and Application Network, University of Maryland Center for Environmental Science (ian.umces.edu/imagelibrary/).

transport to streams is generally less efficient, especially for phosphorus (fig. 41). The generally flat landscape, extremely permeable soils beneath agricultural areas, and forested riparian zones along most of the Nanticoke River likely limit runoff and associated phosphorus transport in many parts of the watershed. Potential reduction of nitrate transport in riparian areas, however, is limited by channelization, that has disconnected much of the stream network from riparian wetlands and the thick surficial aquifer, which allows much of the nitrate in groundwater to bypass the riparian zone and discharge directly through sandy streambed sediments (see sidebar: "Nitrate Removal Through Denitrification, and Limitations Caused by Local Hydrogeology”) (fig. 30-3) (Clune and Denver, 2012). The Nanticoke River watershed is larger with greater overall inputs than the other major watersheds (fig. 41), and a greater reduction in nitrogen (470 tons) and phosphorus (24 tons) is required to meet the Chesapeake Bay TMDL (fig. 13). 


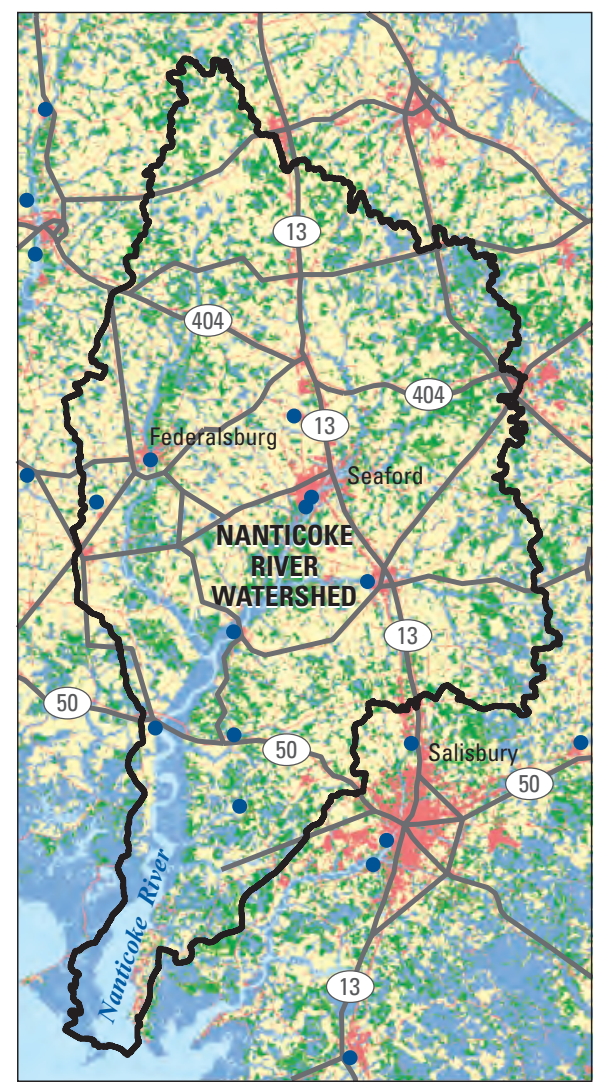

Land cover from LaMotte, 2008a, b

NITROGEN

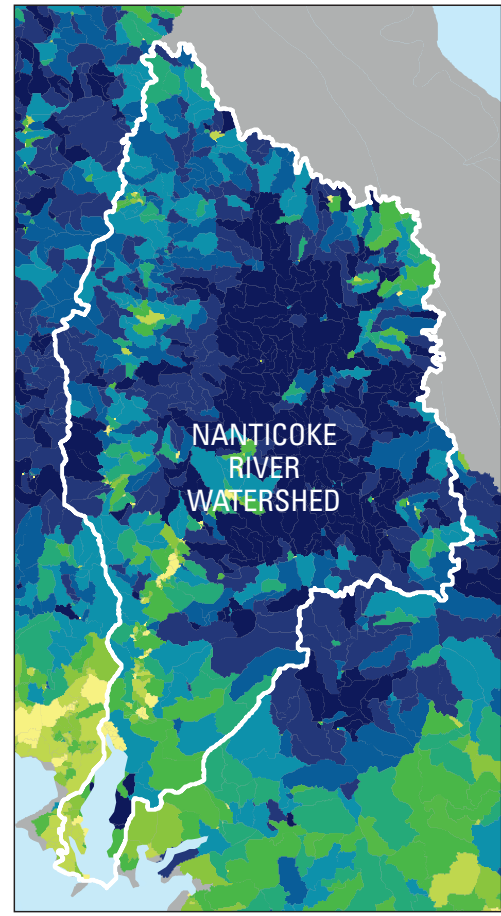

Estimated nutrient yields from Ator and others, 201
PHOSPHORUS

\begin{tabular}{|c|c|}
\hline \multicolumn{2}{|c|}{$\begin{array}{l}\text { EXPLANATION } \\
\text { Land cover }\end{array}$} \\
\hline \multirow{2}{*}{$\begin{array}{l}\text { Agriculture } \\
\text { Urban }\end{array}$} & Wetland \\
\hline & Open water \\
\hline Forest & $\begin{array}{l}\text { - Nutrient point } \\
\text { source }\end{array}$ \\
\hline \multicolumn{2}{|c|}{$\begin{array}{c}\text { Estimated annual yield to local streams, } \\
\text { in kilograms per hectare } \\
\text { (pounds per acre) }\end{array}$} \\
\hline NITROGEN & PHOSPHORUS \\
\hline LE 2 (1.8) & LE $0.05(0.04)$ \\
\hline GT 2 and LE 3 (2.7) & GT 0.05 and LE $0.1(0.09)$ \\
\hline GT 3 and LE 4 (3.6) [ & GT 0.1 and LE $0.2(0.18)$ \\
\hline GT 4 and LE 5 (4.4) & GT 0.2 and LE $0.3(0.27)$ \\
\hline GT 5 and LE 7 (6.2) & GT 0.3 and LE $0.5(0.44)$ \\
\hline GT 7 and LE 10 (8.8) & GT 0.5 and LE 0.8 (0.71) \\
\hline GT 10 and LE 14 (12) & GT 0.8 and LE $1(0.88)$ \\
\hline GT 14 and LE 17 (15) & GT 1 and LE 1.5 (1.3) \\
\hline GT 17 and LE $22(20)$ & GT 1.5 and LE 2 (1.8) \\
\hline GT22 & GT 2 \\
\hline
\end{tabular}

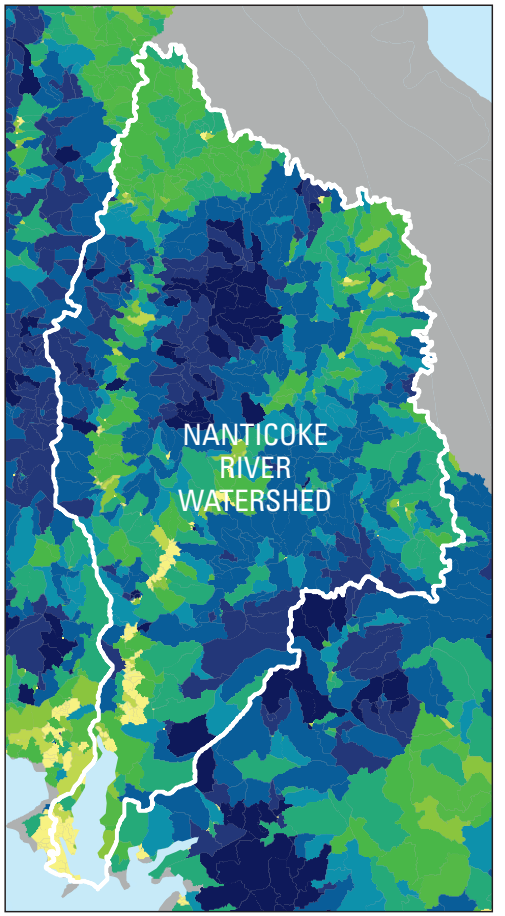

Estimated nutrient yields from Ator and others, 2011

Figure 44. The Nanticoke River watershed. The watershed is the largest of the major watersheds on the Eastern Shore, covering about 2,120 square kilometers. Nutrient yields to streams are generally greatest in the central part of the watershed where agriculture is concentrated. (GT = greater than; $L E=$ less than or equal to.) 


\section{Pocomoke River Watershed}

Water quality in the Pocomoke River watershed reflects particularly poor natural drainage and complex natural and human-impacted groundwater hydrology in the upstream watershed. Unlike the other major watersheds on the Eastern Shore, the Pocomoke River watershed is extremely flat, low-lying, and poorly drained with large tracts of forested wetlands (fig. 45). Soils in many areas are sandy, however, and have been effectively drained to support crop production with nearly $2,000 \mathrm{~km}$ of artificial ditching (Bricker and others, 2003). The Pocomoke River channel and its major tributaries also have been straightened and channelized, although extensive riparian wetlands remain (fig. 40). Poultry production is widespread in agricultural areas and manure applications constitute most of the nitrogen and phosphorus inputs to the landscape (fig. 41). Agriculture contributes more than 80 percent of the nitrogen and 90 percent of the phosphorus load from the watershed to Chesapeake Bay (fig. 41).

Water quality in the Pocomoke River watershed reflects a complex shallow groundwater-flow system (see sidebar: "Nitrate Removal Through Denitrification, and Limitations Caused by Local Hydrogeology") (fig. 30-4). Nitrate is lost over time to denitrification in groundwater in a thin (generally 3- to 6-m thick) shallow surficial aquifer, but has been measured at concentrations as high as $60 \mathrm{mg} / \mathrm{L}$ (Phillips and Donnelly, 2003). Nitrate is generally undetectable, however, in an underlying anoxic aquifer (Ator, Denver, and Brayton, 2005; Denver and others, 2010). When the water table is high, short flow paths to drainage ditches in the shallow aquifer contribute an important source of flow and relatively rapid transport of nitrate to local surface waters (Ator, Denver, and Brayton, 2005; McCoy, Sigrist, and others, 2010). When ditches are dry or stagnant during drier periods, however, longer flow paths in the deeper aquifer maintain base flow in streams. Concentrations of nitrate as high as $15 \mathrm{mg} / \mathrm{L}$ have been measured in headwaters ditches and decrease downstream as more denitrified water from the surficial aquifer and deeper water from the underlying aquifer discharges to streams. Concentrations of nitrate in the main stem of the Pocomoke River range from less than $1 \mathrm{mg} / \mathrm{L}$ to about $5 \mathrm{mg} / \mathrm{L}$ with a median of about $2 \mathrm{mg} / \mathrm{L}$ (Ator, Denver, and Brayton, 2005).

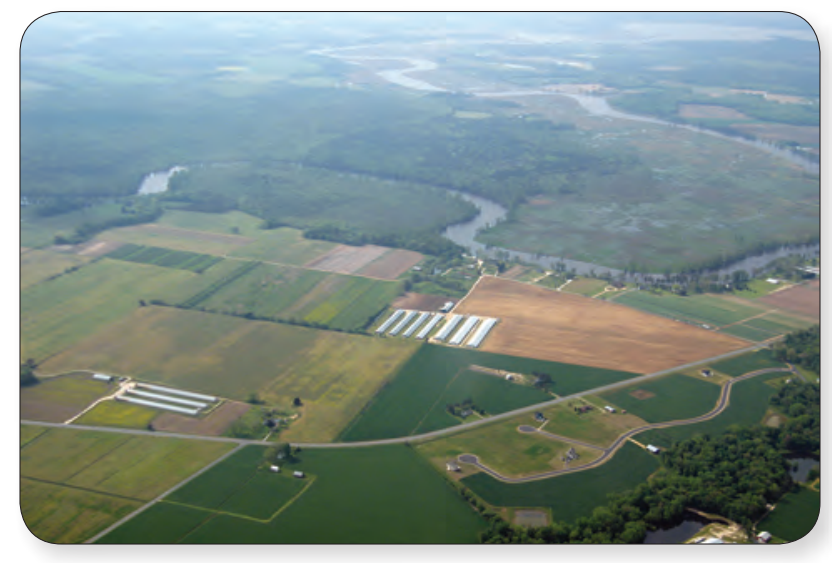

Pocomoke River. Photograph by Ben Fertig, Integration and Application Network, University of Maryland Center for Environmental Science (ian.umces.edu/imagelibrary/).

Concentrations of total phosphorus in the Pocomoke River are generally below $0.2 \mathrm{mg} / \mathrm{L}$ during base flow but increase to over $1 \mathrm{mg} / \mathrm{L}$ during stormflow. Phosphorus attached to soil particles is mobilized by bank erosion in the field ditches or suspended bed load in streams (Ator, Denver, and Brayton, 2005). Soil-bound phosphorus from excessive historical applications represents a continuing source of phosphorus to surface waters and therefore greatly complicates management efforts to restore water quality (McCoy, Sigrist, and others, 2010). Another potential source of phosphorus in the Pocomoke River system is groundwater discharge from the deeper anoxic aquifer where concentrations of dissolved phosphorus greater than $0.6 \mathrm{mg} / \mathrm{L}$ have been measured (Shedlock and others, 1999). This phosphorus is bound to iron particles that form in the flood plains and can dissolve in anoxic conditions (Bricker and others, 2003).

In spite of relatively high rates of applied nitrogen and phosphorus in the Pocomoke River watershed, average yields to the bay are generally lower than from other major watersheds (fig. 41). The required nitrogen and phosphorus load reductions as part of the Chesapeake Bay TMDL are smaller than in the Chester, Choptank, Nanticoke, or Virginia Coastal watersheds, at about 58 tons and 7 tons per year, respectively (fig. 13). 


\section{NITROGEN}

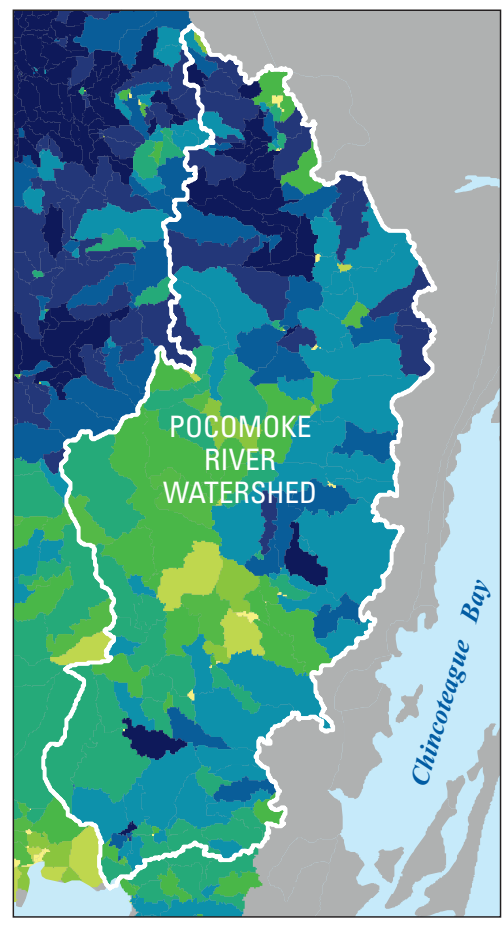

Estimated nutrient yields from Ator and others, 2011

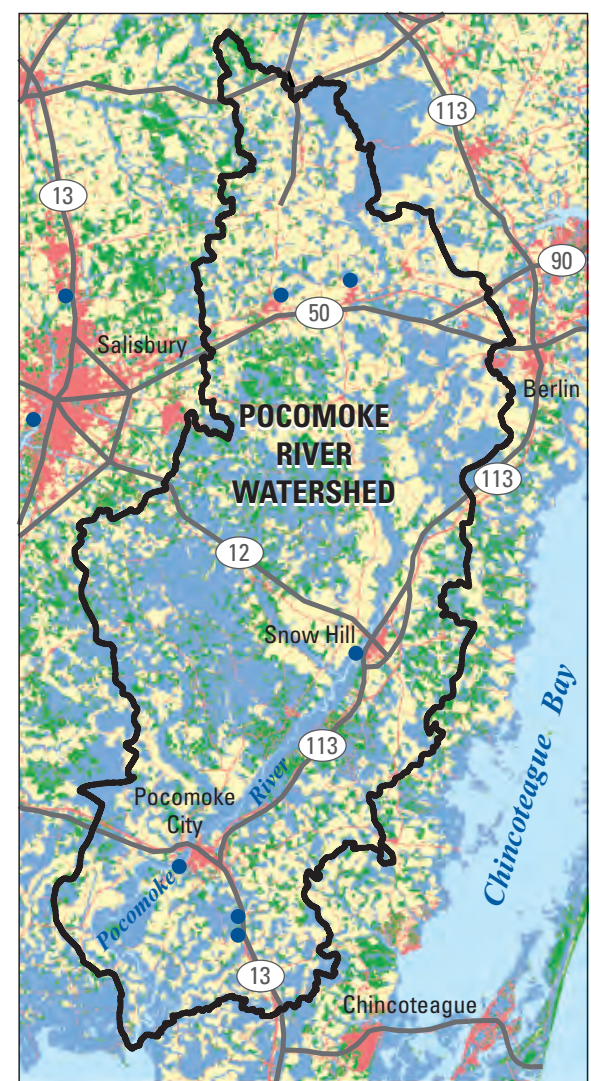

Land cover from LaMotte, 2008a, b

\begin{tabular}{|c|c|}
\hline \multicolumn{2}{|c|}{$\begin{array}{l}\text { EXPLANATION } \\
\text { Land cover }\end{array}$} \\
\hline \multirow{2}{*}{$\begin{array}{l}\text { Agriculture } \\
\text { Urban }\end{array}$} & Wetland \\
\hline & Open water \\
\hline Forest & $\begin{array}{l}\text { Nutrient point } \\
\text { source }\end{array}$ \\
\hline \multicolumn{2}{|c|}{$\begin{array}{c}\text { Estimated annual yield to local streams, } \\
\text { in kilograms per hectare } \\
\text { (pounds per acre) }\end{array}$} \\
\hline NITROGEN & PHOSPHORUS \\
\hline LE 2 (1.8) & LE $0.05(0.04)$ \\
\hline GT 2 and LE 3 (2.7) & GT 0.05 and LE 0.1 (0.09) \\
\hline GT 3 and LE 4 (3.6) & GT 0.1 and LE 0.2 (0.18) \\
\hline GT 4 and LE 5 (4.4) & GT 0.2 and LE $0.3(0.27)$ \\
\hline GT 5 and LE 7 (6.2) & GT 0.3 and LE $0.5(0.44)$ \\
\hline GT 7 and LE 10 (8.8) & GT 0.5 and LE $0.8(0.71)$ \\
\hline GT 10 and LE 14 (12) & GT 0.8 and LE 1 (0.88) \\
\hline GT 14 and LE 17 (15) & GT 1 and LE 1.5 (1.3) \\
\hline GT 17 and LE 22 (20) & GT 1.5 and LE 2 (1.8) \\
\hline GT 22 & GT 2 \\
\hline
\end{tabular}

Figure 45. The Pocomoke River watershed. The watershed covers about 1,225 square kilometers and land use is predominantly forested with wetlands. Nutrient yields from the land surface to streams are generally lower than in other major watersheds, particularly where agriculture is interspersed with poorly drained soils and wetlands. (GT = greater than; $\mathrm{LE}=$ less than or equal to.)

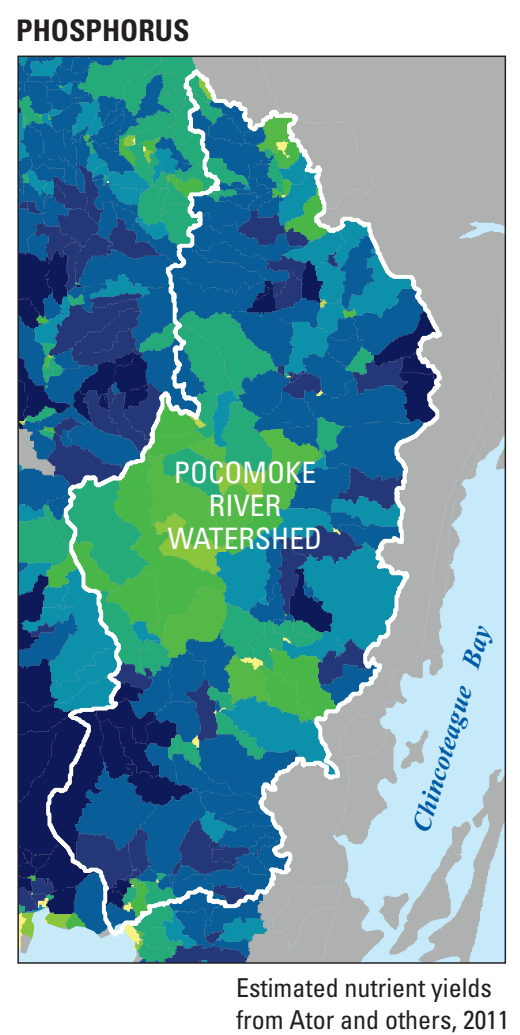




\section{Virginia Coastal Watersheds}

The Delmarva Peninsula in Virginia is a narrow spit of land that runs generally from north to south (fig. 46), and streams in the Virginia Coastal watersheds on the Eastern Shore flow generally to the west over relatively short distances from a well-drained upland near the watershed divide in the east to tidal waters of Chesapeake Bay in the west. The average land-surface elevation is only about $5 \mathrm{~m}$ (fig. 17). Coastal lowlands along Chesapeake Bay are generally poorly drained with forests and wetlands in the north but include excessively well-drained sandier soils in the south (figs. 19, 20). Agriculture (including the production of corn, soybeans, small grains, poultry, and vegetables) and rural residential development is therefore confined to uplands near the drainage divide in the north, but extend from the drainage divide to the shore of the bay, often with no fringing wetlands, in the south (fig. 46). Variable drainage conditions and the resulting land use are reflected in in-stream nitrogen yields that are generally greater in the south than in the north; phosphorus yields are greatest in agricultural areas near the drainage divide (fig. 46). Agricultural sources provide 79 percent of the nitrogen load and 81 percent of the phosphorus load from the watersheds to Chesapeake Bay (fig. 41). A reduction of 401 tons of nitrogen and 25 tons of phosphorus, annually, will be required from the Virginia Coastal watersheds to meet the TMDL for Chesapeake Bay; unlike in other major watersheds, the majority of nitrogen reduction from this area will be required from wastewater treatment or combined sewer overflows (fig. 13).

Nitrate concentrations in streams and groundwater of the Virginia Coastal watersheds reflect variable land use and hydrogeologic conditions, as in other areas of the Eastern Shore. Concentrations in groundwater beneath agricultural fields commonly exceed $10 \mathrm{mg} / \mathrm{L}$ where sandy soils and dissolved oxygen are abundant, but are less than $1 \mathrm{mg} / \mathrm{L}$ in areas with fine-grained organic-rich soils where dissolved oxygen is lacking (Speiran, 1996) (see sidebar: "Nitrate Removal Through Denitrification, and Limitations Caused by Local

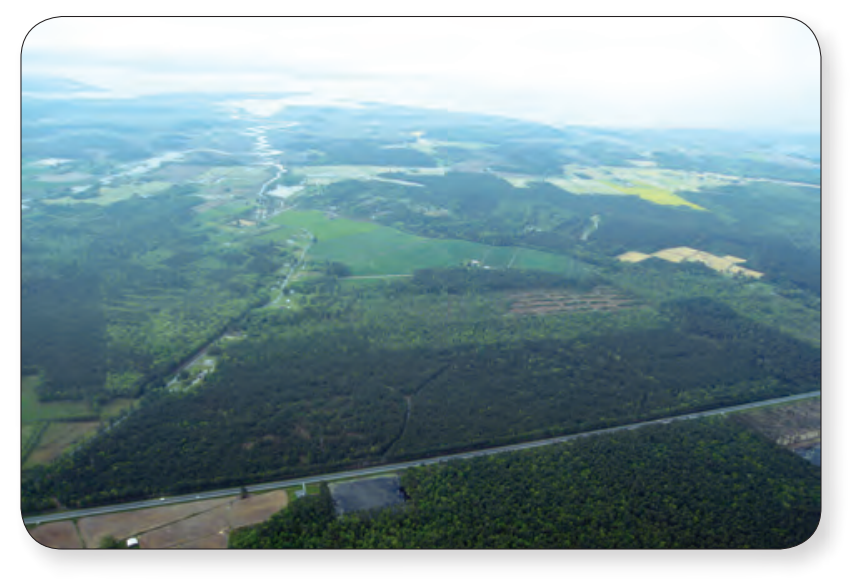

The Eastern Shore of Virginia. Photograph by Ben Fertig, Integration and Application Network, University of Maryland Center for Environmental Science (ian.umces.edu/ imagelibrary/).

Hydrogeology"). Groundwater discharge carries nitrate directly to tidal waters through coarse-textured sediments, even beneath forested buffers with fine-textured sediments along the shoreline. In areas with fine-textured sediments, however, nitrate in groundwater is generally removed through denitrification prior to discharge (Speiran, 1996). On average, nearly one-quarter (23 percent) of nitrogen applied to upland landscapes in the Virginia Coastal watersheds is carried in streamflow to Chesapeake Bay; nitrogen transport from this area is generally more efficient than from other major watersheds (fig. 41), possibly because relatively short transport distances from upland source areas to tidal waters (particularly in the south) limit opportunities for nitrogen loss or sequestration in uplands. Phosphorus delivery from upland source areas in the Virginia Coastal watersheds to Chesapeake Bay is similar to other parts of the Eastern Shore with similarly flat landscapes, such as the adjacent Pocomoke River watershed (fig. 45). 


\section{NITROGEN}

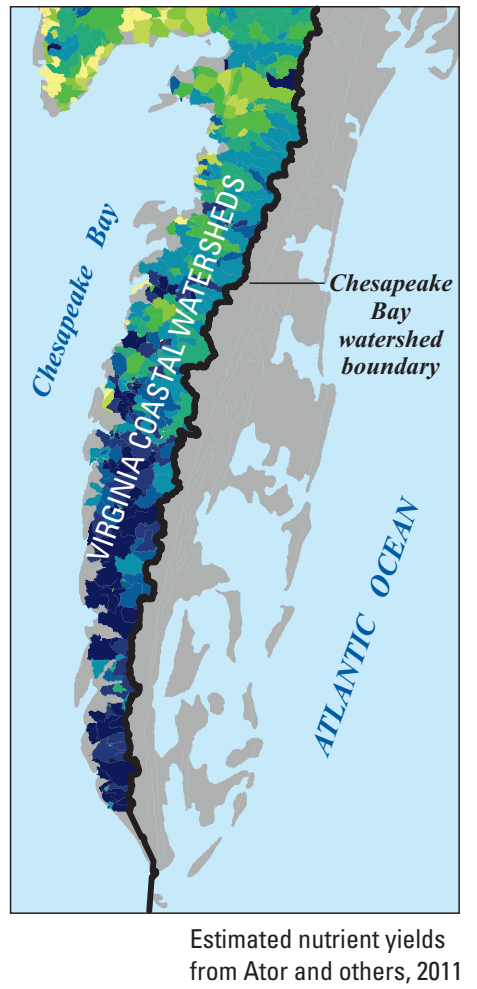

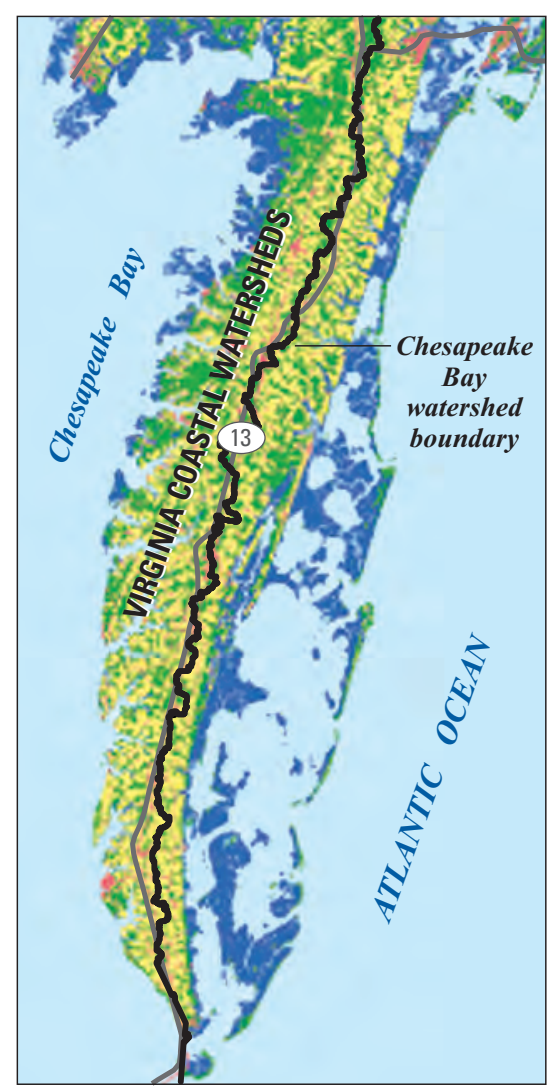

Land cover from LaMotte, 2008a, b

\begin{tabular}{|c|c|}
\hline \multicolumn{2}{|c|}{$\begin{array}{l}\text { EXPLANATION } \\
\text { Land cover }\end{array}$} \\
\hline \multirow{3}{*}{$\begin{array}{l}\text { Agricultur } \\
\text { Urban } \\
\text { Forest }\end{array}$} & \multirow{3}{*}{$\begin{array}{l}\text { Wetland } \\
\text { Open water }\end{array}$} \\
\hline & \\
\hline & \\
\hline \multicolumn{2}{|c|}{$\begin{array}{c}\text { Estimated annual yield to local streams, } \\
\text { in kilograms per hectare } \\
\text { (pounds per acre) }\end{array}$} \\
\hline NITROGEN & PHOSPHORUS \\
\hline LE 2 (1.8) & LE $0.05(0.04)$ \\
\hline GT 2 and LE 3 (2.7) & GT 0.05 and LE 0.1 (0.09) \\
\hline GT 3 and LE 4 (3.6) & GT 0.1 and LE 0.2 (0.18) \\
\hline GT 4 and LE 5 (4.4) & GT 0.2 and LE $0.3(0.27)$ \\
\hline GT 5 and LE 7 (6.2) & GT 0.3 and LE $0.5(0.44)$ \\
\hline GT 7 and LE 10 (8.8) & GT 0.5 and LE $0.8(0.71)$ \\
\hline GT 10 and LE 14 (12) & GT 0.8 and LE $1(0.88)$ \\
\hline GT 14 and LE 17 (15) & GT 1 and LE 1.5 (1.3) \\
\hline GT 17 and LE 22 (20) & GT 1.5 and LE 2 (1.8) \\
\hline GT 22 & GT 2 \\
\hline
\end{tabular}

\section{PHOSPHORUS}

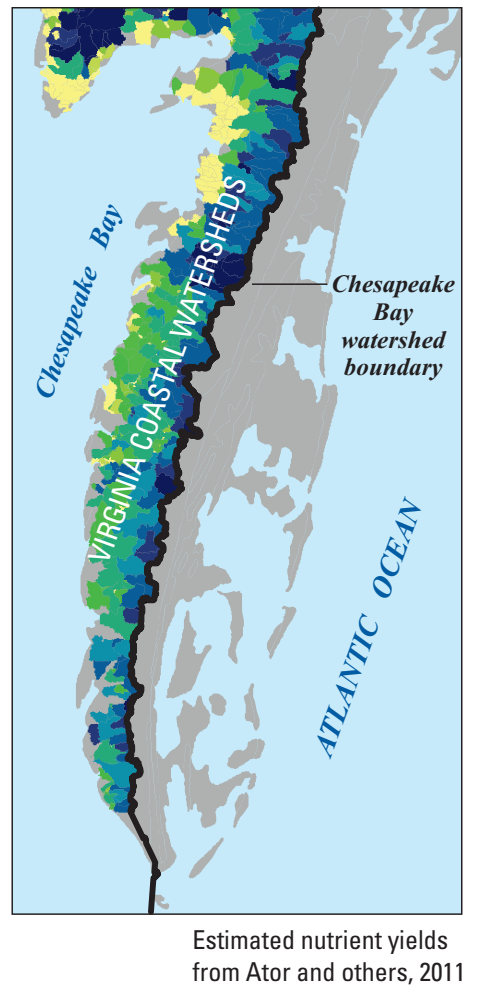

Figure 46. The Virginia Coastal watersheds. These watersheds are generally small, and streams and groundwater flow over relatively short distances before discharging to tidal waters. Average nitrogen yields from the watersheds vary from north to south with similar changes in land use and drainage characteristics; phosphorus yields are generally highest near the watershed divide in the east. (GT = greater than; $\mathrm{LE}=$ less than or equal to.) 


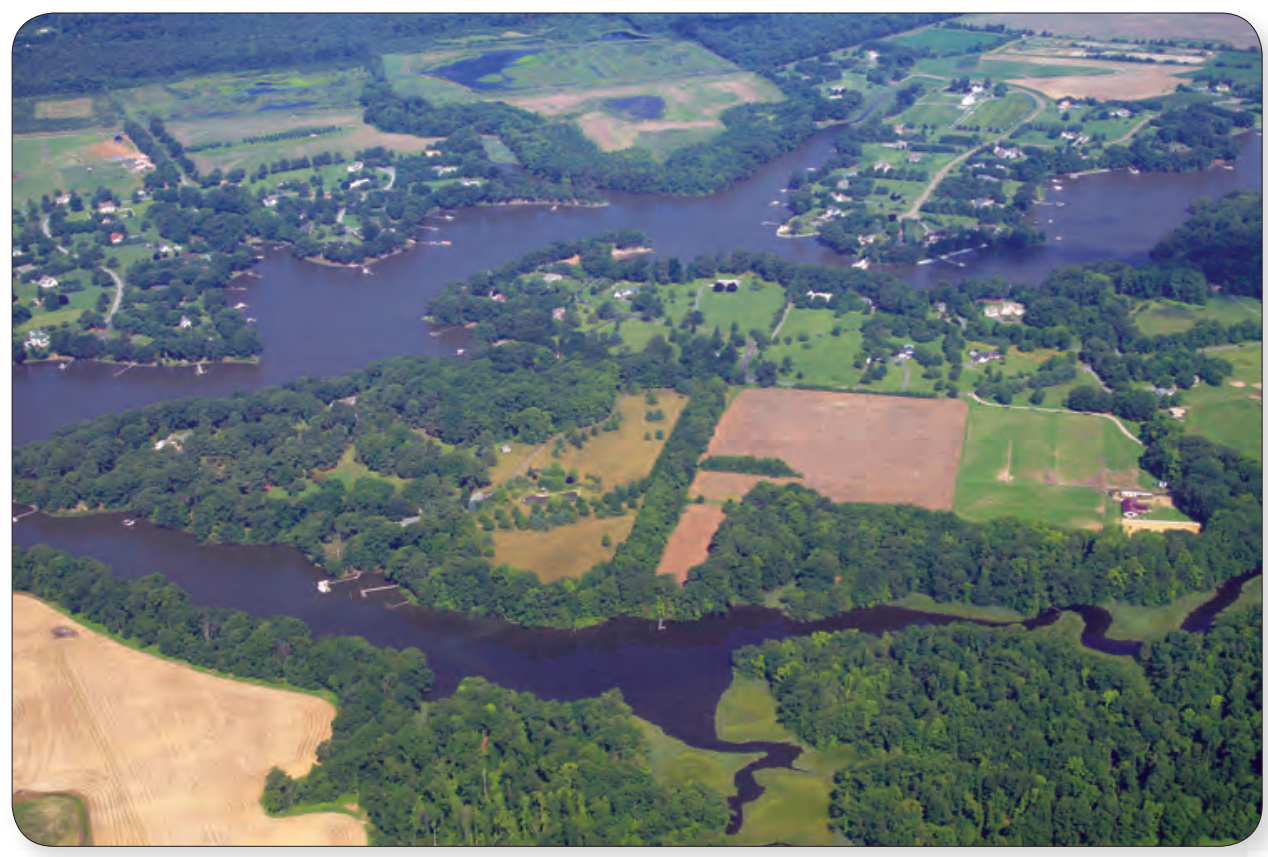

Wye River near Bryantown, Maryland. Photograph by Jane Thomas, Integration and Application Network, University of Maryland Center for Environmental Science (ian.umces. edu/imagelibrary/).

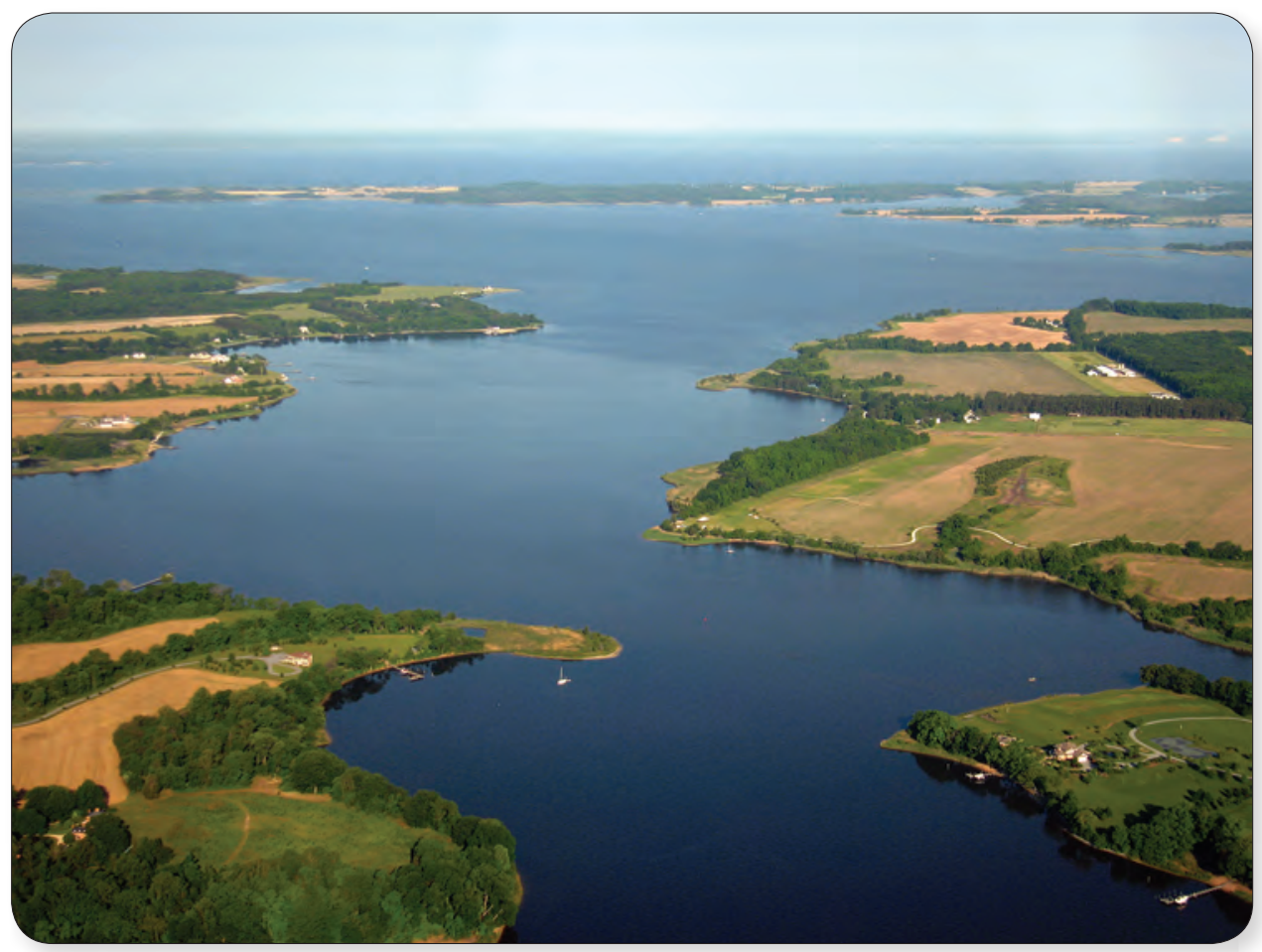

Mouth of the Corsica River flowing into the Chester River, Eastern Shore of Maryland. Photograph by Ben Longstaff, Integration and Application Network, University of Maryland Center for Environmental Science (ian.umces.edu/imagelibrary/). 


\section{Chapter 5. Understanding Nitrogen in Support of Water Resource Management on the Eastern Shore}

\author{
Why are nitrogen concentrations elevated in Eastern \\ Shore groundwater and streams, and why are they continu- \\ ing to increase? What management practices might reduce \\ nitrogen concentrations and how much time will this take?
}

Natural hydrogeologic and geochemical conditions promote the formation and movement of nitrate from the abundant (primarily agricultural) nitrogen sources on the Eastern Shore to groundwater, streams, and estuaries. Increasing nitrate concentrations over time largely reflect increasing nitrogen applications in previous decades. Limiting the movement of nitrate to the water table could reduce concentrations very quickly in shallow groundwater, although many years or decades would be required before significant reductions occur in deeper groundwater or receiving surface waters.

\section{Why are nitrogen concentrations elevated in Eastern Shore groundwater and streams?}

Widespread and abundant nitrogen sources and natural soil and aquifer conditions conducive to the transport and stability of nitrate in the environment are responsible for elevated nitrate concentrations in groundwater and surface waters on the Eastern Shore. The application of manure and fertilizers to agricultural areas is the predominant source of nitrogen to the landscape on the Eastern Shore (see Chapter 3), and agriculture occurs widely throughout the area (see Chapter 2). The average intensity of nitrogen applications to the landscape on the Eastern Shore is consequently much higher than in the remainder of the Chesapeake Bay watershed (fig. 11). Some of the nitrogen that is applied, but not used, by crops or other plants moves directly over the land surface to streams with storm runoff, but the majority is converted to nitrate in the soil and moves through the ground with infiltrating precipitation to groundwater (Ator and Denver, 2012). Natural soil and aquifer conditions in much of the Eastern Shore (particularly in the areas most suitable for agriculture) ensure that nitrate is generally stable for long periods and is not typically lost to the atmosphere through denitrification or to other environmental processes. Also, nitrate is very soluble and moves easily with groundwater to withdrawal wells or to discharge areas in surface waters (see Chapter 3). As a result, nitrate concentrations in streams and groundwater on the Eastern Shore are among the highest in the Chesapeake Bay watershed (figs. 9, 12) and the entire United States (figs. 32, 33).

\section{Why are nitrogen concentrations in streams and groundwater on the Eastern Shore increasing?}

Increasing nitrogen concentrations in groundwater and streams on the Eastern Shore reflect increasing nitrogen applications in previous decades. Nitrate concentrations in groundwater in parts of the surficial aquifer on the Eastern Shore have increased in recent decades (fig. 34), in spite of relatively constant nitrogen applications during the same period (fig. 25) (Debrewer and others, 2007, 2008). Nitrogen concentrations in selected streams on the Eastern Shore have similarly increased recently (fig. 39), primarily due to increasing nitrate in contributing groundwater (Hirsch and others, 2010). Because most nitrogen movement to streams on the Eastern Shore occurs in the form of nitrate through groundwater (fig. 27) (Ator and Denver, 2012), and groundwater flow is very slow (fig. 23) (Dunkle and others, 1993; Sanford and others, 2012), several years or decades are often required before the effects of changes in nitrogen application rates, land-management, or other practices are fully reflected in streams and groundwater chemistry. Increasing nitrate in groundwater on the Eastern Shore between 1988 and 2001 was the result of increasing nitrogen applications through the 1970s (fig. 25) (Debrewer and others, 2007, 2008).

\section{Most nitrogen moves from landscape application areas to Eastern Shore streams through groundwater very slowly over a period of multiple years or decades. Consequently, changes over time that are observed in Eastern Shore streams reflect increasing or relatively high nitrogen applications in past decades.}

Comprehensive information about land management could support a more thorough understanding of changes over time in nitrogen concentrations in groundwater and streams on the Eastern Shore. Certain land-management practices may substantially reduce nitrogen movement from upland source areas to groundwater and streams and have been increasingly used on the Eastern Shore in recent years for that purpose (see following sections). Changes over time in water quality are often gradual, however, and can be difficult to detect and (especially) to explain. Although available regional summaries of management practices over counties or large watersheds can be useful for comparison to similarly broad spatial patterns in water quality, more detailed information about the nature, extent, and location of such practices would support a more thorough understanding of their importance to waterquality trends. 


\section{What management practices might be most effective at reducing nitrogen concentrations?}

Managing agriculture and other human activities on the landscape to limit the movement of nitrogen from source areas to surface waters typically involves limiting nitrogen applications and (or) modifications to increase the effectiveness of natural nitrogen removal. Management practices designed to limit runoff and soil losses (such as riparian buffers, contour tillage, or manure or fertilizer injection) also may be effective at limiting the movement of nitrogen in particulate form from the land surface to surface waters (Staver and Brinsfield, 2010a). Nitrogen, however, moves from the landscape to streams on the Eastern Shore primarily through groundwater in the form of nitrate (Ator and Denver, 2012). Such practices may limit nitrate transport through groundwater in certain hydrogeologic settings (Böhlke and Denver, 1995; Lowrance and others, 1997; Puckett, 2004; Puckett and others, 2008), but may be relatively ineffective for reducing nitrogen transport in other areas and may actually promote the movement of nitrogen retained on fields to groundwater. Winter cover crops can sequester excess soil nitrogen in vegetation and thereby limit losses to groundwater (Staver and Brinsfield, 1998; Hively and others, 2009; McCoy, Spotts, and others, 2010; Staver and Brinsfield, 2010a, b) (fig. 47). When not needed, limiting manure applications on fields for crops may limit nutrient losses over the land surface and to groundwater (Staver and Brinsfield, 2001); the State of Delaware plans to prohibit winter manure applications and relocate manure to nutrient poor areas as part of efforts to limit nutrient losses to the bay (Kleinman and others, 2012). Wetland restoration and controlled-drainage structures have been used to retain water on the landscape and increase the likelihood of nitrogen losses through denitrification (Sadeghi and others, 2008).

Various conditions and processes limit the effectiveness of management practices for reducing nitrogen transport from the land surface to surface waters. Nitrate may be reduced to
Local hydrologic and geologic conditions specific to different areas substantially affect the movement of nitrogen from uplands to streams, and therefore, the effectiveness of management practices intended to limit nitrogen in streams.

nitrogen gas in anoxic riparian areas, but often passes beneath riparian zones to discharge areas in streams (Böhlke and Denver, 1995; Denver and others, 2010). Variable hydrogeologic conditions on the Eastern Shore contribute to variable nutrient retention in riparian buffers; nitrate losses may be substantial where a thin surficial aquifer restricts groundwater to shallow flow paths, but minimal where a thicker surficial aquifer permits deeper groundwater flow (Lowrance and others, 1997; Ator, Denver, Krantz, and others, 2005).

Restoration of streamside buffer areas to grass or forest in the Choptank River watershed failed to decrease base-flow nitrogen concentrations in streams between 1986 and 2006, although this may be attributable to coincident increasing nitrogen applications or to insufficient buffer width, age, or extent (Sutton and others, 2010). Nitrogen losses in riparian zones also depend upon the types and amounts of available carbon, such as from leaf litter and other plants (McCarty and others, 2007). The effectiveness of cover crops at reducing nitrogen losses to groundwater varies with the species of cover crop and previous crop, the method and date of planting, soil types, and precipitation (Ritter and others, 1998; Hively and others, 2009; Staver and Brinsfield, 2010a). Nitrogen removal in artificial ditches varies with ditch management, including ponding to retain water on the landscape during certain periods and dredging frequency (Sadeghi and others, 2008; Shigaki and others, 2009).

With any management technique that is used, significant differences between nitrogen and phosphorus requirements for plant growth, content in animal manure commonly applied to cropland on the Eastern Shore, and chemical and physical properties controlling environmental fate and transport, substantially complicate the design of management practices that would be effective for both nutrients (Staver and Brinsfield, 2001). Removal of manure and the use of chemical fertilizers to customize applications to crop needs can substantially reduce nutrient applications to crops in excess of plant needs (McCoy, Sigrist, and others, 2010).

Figure 47. Changes in nitrate concentrations over time in groundwater beneath adjacent fields after the initiation of winter cover crops in 1988. Groundwater nitrate concentrations decreased after use of cover crops began. 


\section{How long will it take to see water-quality improvement and, in the meanwhile, how will we know if land-management or restoration practices are working?}

Significant time periods often pass before management practices produce the desired effects on local waters, these effects are propagated downstream, and receiving waters respond to these effects (Meals and others, 2010). The effects of landscape management practices designed to reduce nitrogen pollution in Eastern Shore streams will require years to become fully realized in surface waters, but would likely become apparent more quickly in shallow groundwater beneath nitrogen application areas. If precision applications, cover crops, or other management practices are effective in reducing nitrogen leaching from the land surface to the water table, such reductions should be evident very quickly with reduced nitrate concentrations in shallow groundwater and water of the overlying unsaturated zone (fig. 47). If these reductions are sustained over time, lower nitrate concentrations will continue to move slowly along groundwater flow paths as water from previous years with higher nitrate concentrations moves out of the system to streams. Eventually, nitrate concentrations in streams will begin to decrease with increasing discharge of groundwater with reduced nitrate concentrations. In general, small streams receive water from primarily shorter groundwater flow paths and will therefore improve more quickly, although larger streams that receive water from longer flow paths may require much more time.

Decades will likely be required before the effects of management practices at the land surface are reflected in decreasing nitrogen contributed to the Chesapeake Bay from streams on the Delmarva Peninsula. Nutrient management practices have reduced nitrogen losses from the land surface to streams since the 1970s (Sanford and Pope, 2013), and the use of cover crops that may specifically limit nitrogen movement to the water table has increased on the peninsula in recent years (fig. 48). Because groundwater flow is very slow, however, much of the nitrogen from previous decades remains in the groundwater system and will continue to discharge to streams in future years. For this reason, even stable fertilizer and manure applications at average 2007-12 levels will result in continuously increasing nitrogen in streams in future decades, and an estimated 13-percent reduction in such applications would be required simply to maintain in-stream nitrogen at current levels (fig. 49). Even a 40-percent reduction of nitrogen at the water table would be insufficient to reduce annual nitrogen loads from the peninsula to Chesapeake Bay to an estimated 5,000 metric tons, the U.S. Environmental Protection Agency (EPA) target for bay restoration, within the next 35 years (fig. 49). If nitrogen movement to the water table were to stop completely, the restoration goal would likely be met by 2020 , but as much as 2,500 metric tons of nitrogen would continue to discharge annually from groundwater to Delmarva streams through at least 2050 (fig. 49) (Sanford and Pope, 2013).

Decades will be required before nitrogen currently in Eastern

Shore groundwater moves through to local streams and the

effects of any current land-management practices on surfacewater quality are fully realized. 


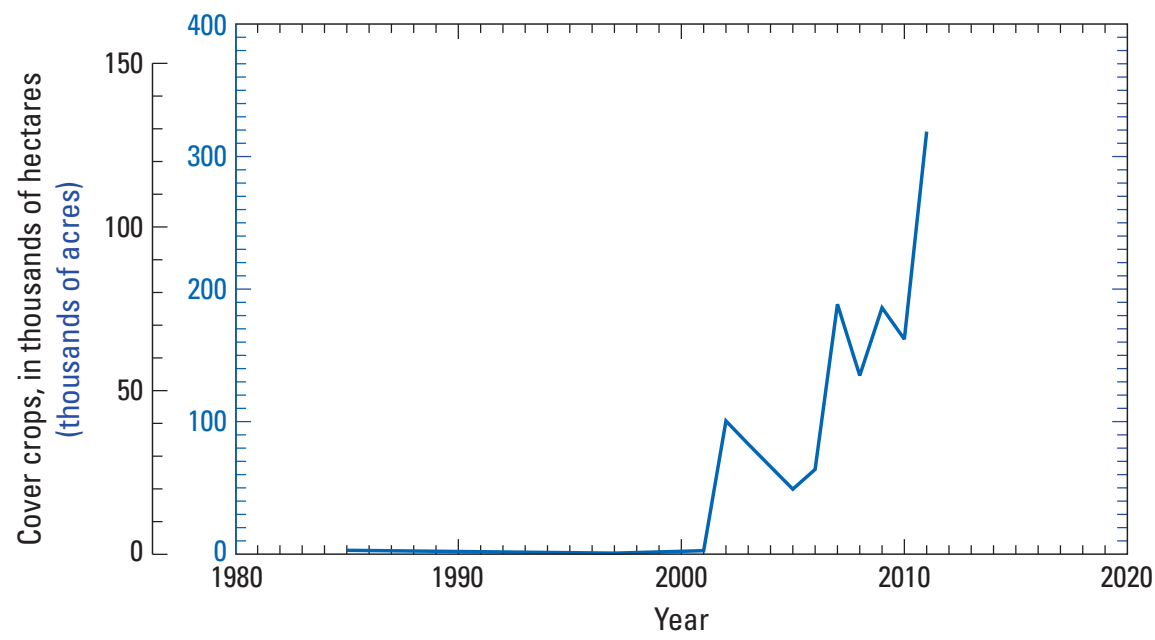

[Data from M. Johnston, Chesapeake Bay Program, written commun., March 14, 2013.]

Figure 48. Use of cover crops on the Delmarva Peninsula, 1985-2011. Use of cover crops has increased substantially in recent years.

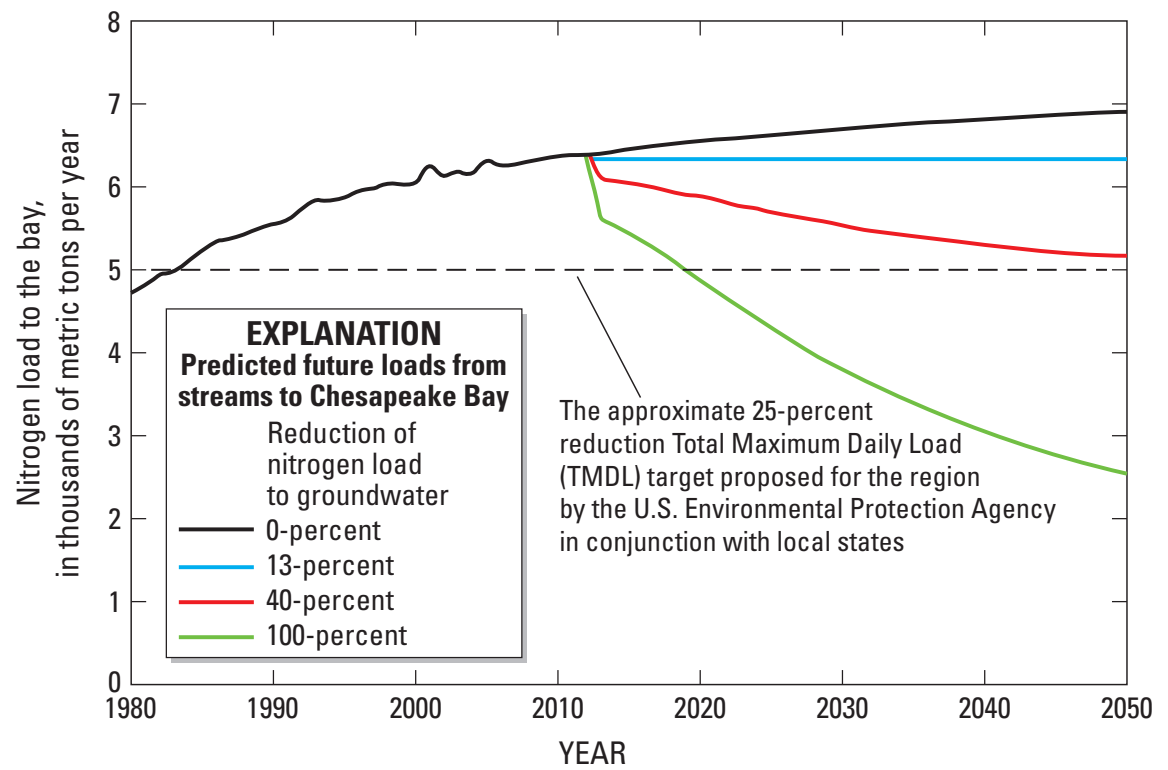

[From Sanford and Pope, 2013.]

Figure 49. Forecasted nitrogen delivery from the Eastern Shore to Chesapeake Bay under selected potential management scenarios. Even if loads of nitrogen to groundwater on the Eastern Shore are substantially reduced in future years, groundwater will continue to discharge nitrate from applications in previous years to Chesapeake Bay tributaries. 


\section{Chapter 6. Understanding Phosphorus in Support of Water Resource Management on the Eastern Shore}

\author{
Why are phosphorus concentrations elevated in \\ sediment and water resources on the Eastern Shore and \\ (in some areas) increasing? What can be done to reduce \\ phosphorus concentrations in the environment and how long \\ might that take?
}

Applications of phosphorus (in livestock manure and fertilizer) to Eastern Shore farmland in recent decades have far exceeded the amounts necessary for crop growth, and phosphorus has consequently increased in the environment. Unlike nitrate, phosphorus is relatively insoluble in water under most natural conditions, and excess phosphorus in the environment generally accumulates in agricultural soils rather than moving into groundwater.

\section{Why are phosphorus concentrations elevated in many agricultural soils on the Eastern Shore?}

Phosphorus has accumulated in agricultural soils in parts of the Eastern Shore at levels far in excess of agricultural needs (Staver and Brinsfield, 2001; Leytem and others, 2003). Although phosphorus applications in fertilizer have decreased in recent decades (fig. 25), farming practices on the Eastern Shore since the latter half of the 20th century have generally involved importing phosphorus in fertilizer and (or) applying phosphorus in manure in greater amounts than what is removed in agricultural products (fig. 26). Nutrient management plans for crops often involve limiting the transport of nutrients to water resources by limiting application to crop uptake requirements (Staver and Brinsfield, 2001). Livestock (primarily chickens) on the Eastern Shore produce more than

Phosphorus compounds are relatively insoluble and tend to accumulate in particulate matter (such as soils) in areas of application. Phosphorus applications in excess of crop requirements over a number of years have resulted in elevated phosphorus levels in certain cropland soils.

8 million $\mathrm{kg}$ of phosphorus in manure annually (Wieczorek and LaMotte, 2010c), most of which is spread on croplands. The crop needs for nitrogen and phosphorus generally differ from their relative content in poultry manure, however, and applying manure sufficient to meet crop nitrogen needs often results in a threefold or fourfold over-application of phosphorus (Staver and Brinsfield, 2001). Phosphorus application in fertilizer (fig. 25) and excess over crop needs (fig. 26) have decreased since the latter half of the 20th century; however, applications of phosphorus in fertilizer and manure to cropland on the Eastern Shore in Maryland and Delaware in 2007 remained approximately 5 and 10 kilograms per hectare (respectively) greater than crop needs (fig. 26) (Mid-Atlantic Water Program, 2012). Because phosphorus compounds are relatively insoluble in water, applied phosphorus in excess of crop needs generally attaches to and accumulates in soils rather than moving to groundwater.

\section{Why is phosphorus moving into streams and groundwater on the Eastern Shore?}

Continuing accumulation of excess phosphorus in Eastern Shore soils likely promotes the movement of phosphorus into local streams and groundwater. Phosphorus concentrations in groundwater on the Eastern Shore are typically below $0.1 \mathrm{mg} / \mathrm{L}$, but may be higher in areas with anoxic conditions where phosphorus is more soluble (Denver and others, 2004; Debrewer and others, 2007). Phosphorus concentrations in streams during base flow are similarly generally below 0.1 $\mathrm{mg} / \mathrm{L}$, but are often as high as 3 or $4 \mathrm{mg} / \mathrm{L}$ during storms (Denver and others, 2004; Ator, Denver, and Brayton, 2005). Mean annual phosphorus concentrations in the Pocomoke River are among the highest in the Nation (Denver and others, 2004). Phosphorus is much less soluble than nitrate and typi-

Increasing phosphorus accumulation in Eastern Shore soils may make newly applied phosphorus more likely to move into groundwater and streams.

cally attaches to solid particles such as soil or sediment grains rather than dissolve in water. Soils can only hold a limited amount of phosphorus, however, and as phosphorus accumulates at higher and higher concentrations, newly applied phosphorus becomes less likely to attach to the soils and more likely to move into groundwater (Staver and Brinsfield, 2001; Maguire and Sims, 2002; Leytem and Sims, 2005; Domagalski and Johnson, 2011). Also, erosion during and following storm events often carries soil, sediment, and attached phosphorus directly to streams in overland runoff. Phosphorus transport from source areas on the land surface to streams is more efficient in the Coastal Plain (particularly the Eastern Shore) than in other areas of the Chesapeake Bay watershed, possibly because of historically excessive phosphorus applications to cropland and resulting greater movement to groundwater or in overland runoff (Ator and others, 2011). 


\section{Why is phosphorus continuing to increase in the Choptank River in recent years?}

In the Choptank River, the largest nontidal Chesapeake Bay tributary on the Eastern Shore, phosphorus concentrations increased significantly between 1985 and 2008, coincident with a significant decrease in suspended-sediment concentrations (Moyer and others, 2012). Because phosphorus movement into and through surface waters generally occurs in solid form attached to soils and other sediment particles, trends in phosphorus concentrations often mimic those in suspended sediment. Increasing phosphorus in the river in recent decades in spite of decreasing sediment concentrations suggests that individual sediment grains in the river carry (on average) greater particulate phosphorus than in the past, and (or) that phosphorus transport to the river in the dissolved phase may be increasing. Although the particular reason for recent phosphorus trends in the river remains unclear, either or both of these conditions could be a result of increasing phosphorus saturation in cropland soils in the Choptank River watershed. As with nitrogen (see Chapter 5), more detailed information about the nature and location of land-management practices intended to limit the movement of phosphorus from agricultural areas to water resources could support a more thorough evaluation of changes over time in phosphorus concentrations in Eastern Shore streams.

\section{What management practices may be most effective at limiting phosphorus movement to Eastern Shore streams and groundwater?}

Land-management practices designed to limit the movement of phosphorus from upland application areas to surface waters often involve limiting soil erosion. Phosphorus compounds are relatively insoluble and typically remain bound to soil particles when applied in excess of crop or other plant needs. Riparian buffers, contour tillage, conservation tillage, and other land-management practices designed to minimize soil erosion are therefore often similarly effective at limiting phosphorus transport (Staver and Brinsfield, 2001). The effectiveness of these practices typically varies significantly among different sites and conditions (Sharpley and others, 2002; Sutton and others, 2010), however, and may be limited in flat areas such as the Eastern Shore, where erosion is unlikely (Staver and Brinsfield, 2010a). Phosphorus has been applied to Eastern Shore crops at rates much higher than crop requirements since at least the 1930s (fig. 26), however, and Eastern Shore soils may have a reduced capacity to absorb additional phosphorus (Ator and others, 2011). In addition, phosphorus retention at the land surface resulting from practices such as conservation tillage may increase the transport of phosphorus in dissolved form (Staver and Brinsfield, 2001; Sharpley and others, 2002). Phosphorus transport increased following no-till practices on one farm in the Wye River watershed in the 1990s because reduced transport of particulate phosphorus was more than offset by increased transport of dissolved phosphorus (Staver and Brinsfield, 2010a). Reducing the reservoir of phosphorus in cropland soils may be effective at reducing phosphorus concentrations in Eastern Shore streams and groundwater. Removing phosphorus from the soil can be accomplished by nutrient management practices to ensure that new applications of phosphorus are smaller than phosphorus removal at harvest (Jarvie and others, 2013).

\section{How long will it take to see water-quality improvement and, in the meanwhile, how will we know if land-management and restoration practices are working?}

Several years or decades may be required before effects of land-management practices are fully realized in surfacewater phosphorus concentrations on the Eastern Shore.

Reducing phosphorus applications below crop requirements should reduce phosphorus levels in cropland soils, although such reductions will occur slowly in areas where excessive soil phosphorus from previous applications greatly exceeded the annual uptake requirements of crops (McCollum, 1991). Riparian buffers, conservation tillage, and other land-management practices intended to limit erosion or sediment transport should be similarly effective at limiting the movement of sediment-associated phosphorus to streams (Staver and Brinsfield, 2001). Such practices may increase the storage of phosphorus in upland landscapes, however, which may require years or decades to move to stream channels (Jarvie and others, 2013). Once sediment and associated phosphorus reaches streams, delivery to downstream tidal waters may be similarly delayed as sediment is deposited within stream channels and transported only intermittently during high-flow periods (Jarvie and others, 2013). Due to the relatively minor role of groundwater in phosphorus transport, long time periods typically required for groundwater flow should be minimally important to phosphorus changes over time in streams. 


\section{References Cited}

Alexander, R.B., and Smith, R.A., 1990, County-level estimates of nitrogen and phosphorus fertilizer use in the United States, 1945 to 1985: U.S. Geological Survey OpenFile Report 90-130, 12 p., accessed November 30, 2005, at http://pubs.er.usgs.gov/publication/ofr90130.

Allen, T.H., 2009, The transformation of forest and marsh in the agricultural landscape of the Lower Delmarva Peninsula: Geocarto International, v. 24, no. 1, p. 37-46, DOI: $10.1080 / 10106040802069706$.

Andres, A.S., Ullman, W.J., and Savidge, K.B., 2007, Stormwater and baseflow sampling and analysis in the Nanticoke River Watershed-Preliminary report of findings, 20022004: Delaware Geological Survey Open-File Report 46, $20 \mathrm{p}$.

Aschebrook-Kilfoy, B., Heltshe, S.L., Nuckols, J.R., Sabra, M.M., Shuldiner, A.R., Mitchell, B.D., Airola, M., Holford, T.R., Zhang, Y., and Ward, M.H., 2012, Modeled nitrate levels in well water supplies and prevalence of abnormal thyroid conditions among the Old Order Amish in Pennsylvania: Environmental Health: A Global Access Science Source, v. 11, no. 1, DOI: 10.1186/1476-069x-11-6.

Ator, S.W., 2008, Natural and human influences on water quality in a shallow regional unconsolidated aquifer, Northern Atlantic Coastal Plain: U.S. Geological Survey Scientific Investigations Report 2008-5190, 21 p., accessed January 8, 2009, at http://pubs.usgs.gov/sir/2008/5190/.

Ator, S.W., Brakebill, J.W., and Blomquist, J.D., 2011, Sources, fate, and transport of nitrogen and phosphorus in the Chesapeake Bay watershed-An empirical model: U.S. Geological Survey Scientific Investigations Report 20115167, 27 p., accessed October 11, 2011, at http://pubs.usgs. gov/sir/2011/5167/.

Ator, S.W., and Denver, J.M., 2012, Estimating contributions of nitrogen and herbicides from groundwater to headwater streams, Northern Atlantic Coastal Plain, USA: Journal of the American Water Resources Association, v. 48, no. 6, p. 1,075-1,090, DOI: 10.1111/j.1752-1688.2012.00672.x, accessed September 12, 2014, at http://onlinelibrary.wiley. com/doi/10.1111/j.1752-1688.2012.00672.x/pdf.

Ator, S.W., Denver, J.M., and Brayton, M.J., 2005, Hydrologic and geochemical controls on pesticide and nutrient transport to two streams on the Delmarva Peninsula: U.S. Geological Survey Scientific Investigations Report 2004-5051, 44 p., accessed January 11, 2005, at http://pubs.water.usgs.gov/ sir20045051/.
Ator, S.W., Denver, J.M., and Hancock, T.C., 2000, Relating shallow ground-water quality to surficial hydrogeology in the Mid-Atlantic Coastal Plain: Proceedings of the National Water-Quality Monitoring Conference, Austin, Texas, April 25-27, 2000, p. 409-423.

Ator, S.W., Denver, J.M., Krantz, D.E., Newell, W.L., and Martucci, S.K., 2005, A surficial hydrogeologic framework for the Mid-Atlantic Coastal Plain: U.S. Geological Survey Professional Paper 1680, 44 p., accessed June 25, 2012, at http://pubs.er.usgs.gov/publication/pp1680.

Bachman, L.J., 1984, Nitrate in the Columbia aquifer, central Delmarva Peninsula, Maryland: U.S. Geological Survey Water-Resources Investigations Report 84-4322, 51 p.

Bachman, L.J., Krantz, D.E., and Böhlke, J.K., 2002, Hydrogeologic framework, ground-water geochemistry, and assessment of nitrogen yield from base flow in two agricultural watersheds, Kent County, Maryland: U.S. Environmental Protection Agency Report EPA/600/R-02/008, 79 p.

Bachman, L.J., Lindsey, B.D., Brakebill, John, and Powars, D.S., 1998, Ground-water discharge and base-flow nitrate loads of nontidal streams, and their relation to a hydrogeomorphic classification of the Chesapeake Bay Watershed, middle Atlantic Coast: U.S. Geological Survey Water-Resources Investigations Report 98-4059, 77 p., accessed December 1, 2000, at http://pubs.water.usgs.gov/ wri98-4059/.

Bachman, L.J., and Phillips, P.J., 1996, Hydrologic landscapes on the Delmarva Peninsula-Part 2: Estimates of base-flow nitrogen load to Chesapeake Bay: Journal of the American Water Resources Association, v. 32, no. 4, p. 779-791.

Battaglin, W.A., and Goolsby, D.A., 1995, Spatial data in geographic information system format on agricultural chemical use-Land use, and cropping practices in the United States: U.S. Geological Survey Water-Resources Investigations Report 95-4176, 87 p., accessed December 1, 2005, at http://pubs.water.usgs.gov/WRI944176.

Böhlke, J.K., and Denver, J.M., 1995, Combined use of groundwater dating, chemical, and isotopic analyses to resolve the history and fate of nitrate contamination in two agricultural watersheds, Atlantic Coastal Plain, Maryland: Water Resources Research, v. 31, no. 9, p. 2,319-2,339, DOI: $10.1029 / 95 \mathrm{wr} 01584$.

Boynton, W.R., Garber, J.H., Summers, R., and Kemp, W.M., 1995, Inputs, transformations, and transport of nitrogen and phosphorus in Chesapeake Bay and selected tributaries: Estuaries, v. 18, no. 1 B, p. 285-314. 
Bratton, J.F., Böhlke, J.K., Krantz, D.E., and Tobias, C.R., 2009, Flow and geochemistry of groundwater beneath a back-barrier lagoon: The subterranean estuary at Chincoteague Bay, Maryland, USA: Marine Chemistry, v. 113, nos. 1-2, p. 78-92, DOI: 10.1016/j. marchem.2009.01.004.

Bratton, J.F., Böhlke, J.K., Manheim, F.T., and Krantz, D.E., 2004, Ground water beneath coastal bays of the Delmarva Peninsula: Ages and nutrients: Ground Water, v. 42, no. 7, p. 1,021-1,034, DOI: 10.1111/j.1745-6584.2004.tb02641.x.

Bratton, J.F., Colman, S.M., and Seal, R.R., II, 2003, Eutrophication and carbon sources in Chesapeake Bay over the last 2,700 yr: Human impacts in context: Geochimica et Cosmochimica Acta, v. 67 , no. 18 , p. 3,385-3,402, DOI: 10.1016/s0016-7037(03)00131-5.

Bricker, O.P., Newell, W.L., and Simon, N.S., 2003, Bog-iron formation in the Nassawango watershed, Maryland: U.S. Geological Survey Open-File Report 03-346, accessed July 24, 2014, at http://pubs.usgs.gov/of/2003/of03-346/. [online only].

Bricker, S., Longstaff, B., Dennison, W., Jones, A., Boicourt, K., Wicks, C., and Woerner, J., 2007, Effects of nutrient enrichment in the Nation's estuaries-A decade of change: NOAA Coastal Ocean Program Decision Analysis Series 26, 328 p., accessed January 27, 2012, at http://ccma.nos. noaa.gov/publications/eutroupdate/.

Chesapeake Bay Program, 2012, Health of freshwater streams in the Chesapeake Bay Watershed, accessed November 12, 2012, at http://www.chesapeakebay.net/indicators/indicator/ health_of_freshwater_streams_in_the_chesapeake_bay_ watershed.

Chesapeake Bay Program, 2014a, ChesapeakeStatWater Quality: TMDL Tracking, accessed March 31-April 9, 2014, at http://stat.chesapeakebay. net/?q=node/130\&quicktabs_10=2.

Chesapeake Bay Program, 2014b, Nitrogen loads and river flow to the bay, accessed April 11, 2014, at http://www.chesapeakebay.net/indicators/indicator/ nitrogen_loads_and_river_flow_to_the_bayl.

Chesapeake Bay Program, 2014c, Water quality standards achievement, accessed April 17, 2014, at http://www.chesapeakebay.net/indicators/indicator/ achievement_of_chesapeake_bay_water_quality_standards.

Clark, G.M., Mueller, D.K., and Mast, M.A., 2000, Nutrient concentrations and yields in undeveloped stream basins of the United States: Journal of the American Water Resources Association, v. 36, no. 4, p. 849-867.
Clune, J.W., and Denver, J.M., 2012, Residence time, chemical and isotopic analysis of nitrate in the groundwater and surface water of a small agricultural watershed in the Coastal Plain, Bucks Branch, Sussex County, Delaware: U.S. Geological Survey Scientific Investigations Report 2012-5235, 15 p., accessed December 6, 2012, at http://pubs.usgs.gov/sir/2012/5235/.

Cushing, E.M., Kantrowitz, I.H., and Taylor, K.R., 1973, Water resources of the Delmarva Peninsula: U.S. Geological Survey Professional Paper 822, 58 p., accessed November 1, 2012, at http://pubs.usgs.gov/pp/0822/report.pdf.

Debrewer, L.M., Ator, S.W., and Denver, J.M., 2007, Factors affecting spatial and temporal variability in nutrient and pesticide concentrations in the surficial aquifer on the Delmarva Peninsula: U.S. Geological Survey Scientific Investigations Report 2005-5257, 45 p., accessed May 10, 2007, at http://pubs.usgs.gov/sir/2005/5257/.

Debrewer, L.M., Ator, S.W., and Denver, J.M., 2008, Temporal trends in nitrate and selected pesticides in Mid-Atlantic ground water: Journal of Environmental Quality, v. 37, no. 5_Supplement, p. S-296-S-308, DOI: 10.2134/jeq2007.0664, accessed December 10, 2012, at https://www.agronomy.org/publications/jeq/ abstracts/37/5_Supplement/S-296.

Denver, J.M., 1986, Hydrogeology and geochemistry of the unconfined aquifer, west-central and southwestern Delaware: Delaware Geological Survey Report of Investigations $41,100 \mathrm{p}$.

Denver, J.M., 1989, Effects of agricultural practices and septic-system effluent on the quality of water in the unconfined aquifer in parts of eastern Sussex County, Delaware: Delaware Geological Survey Report of Investigations 45, $66 \mathrm{p}$.

Denver, J.M., Ator, S.W., Debrewer, L.M., Ferrari, M.J., Barbaro, J.R., Hancock, T.C., Brayton, M.J., and Nardi, M.R., 2004, Water quality in the Delmarva Peninsula, Delaware, Maryland, and Virginia, 1999-2001: U.S. Geological Survey Circular 1228, 40 p., accessed June 1, 2004, at http://pubs.water.usgs.gov/circ1228/.

Denver, J.M., Ator, S.W., Lang, M.W., Fisher, T.R., Gustafson, A.B., Fox, R., Clune, J.W., and McCarty, G.W., 2014, Nitrate fate and transport through current and former depressional wetlands in an agricultural landscape, Choptank Watershed, Maryland, USA: Journal of Soil and Water Conservation, v. 69, no. 1, p. 1-16, DOI: 10.2489/

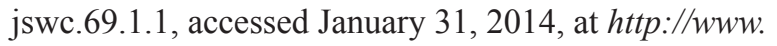
jswconline.org/content/69/1/1.full.pdf+html. 
Denver, J.M., Tesoriero, A.J., and Barbaro, J.R., 2010, Trends and transformation of nutrients and pesticides in a Coastal Plain aquifer system, United States: Journal of Environmental Quality, v. 39, no. 1, p. 154-167, DOI: $10.2134 /$ jeq2009.0107.

Dillow, J.J.A., and Greene, E.A., 1999, Ground-water discharge and nitrate loadings to the coastal bays of Maryland: U.S. Geological Survey Water-Resources Investigations Report 99-4167, 8 p., accessed February 1, 2001, at http:// md.water.usgs.gov/publications/wrir-99-4167/.

Domagalski, J.L., Ator, S., Coupe, R., McCarthy, K., Lampe, D., Sandstrom, M., and Baker, N., 2008, Comparative study of transport processes of nitrogen, phosphorus, and herbicides to streams in five agricultural basins, USA: Journal of Environmental Quality, v. 37, no. 3, p. 1,158-1,169, DOI: 10.2134/jeq2007.0408, accessed July 24, 2014, at https:// www.agronomy.org/publications/jeq/abstracts/37/3/1158.

Domagalski, J.L., and Johnson, H.M., 2011, Subsurface transport of orthophosphate in five agricultural watersheds, USA: Journal of Hydrology, v. 409, nos. 1-2, p. 157-171, DOI: 10.1016/j.jhydrol.2011.08.014.

Dubrovsky, N.M., Burow, K.R., Clark, G.M., Gronberg, J.M., Hamilton, P.A., Hitt, K.J., Mueller, D.K., Munn, M.D., Nolan, B.T., Puckett, L.J., Rupert, M.G., Short, T.M., Spahr, N.E., Sprague, L.A., and Wilber, W.G., 2010, The quality of our Nation's waters-Nutrients in the Nation's streams and groundwater, 1992-2004: U.S. Geological Survey Circular 1350, 174 p., accessed September 24, 2010, at http://pubs. usgs.gov/circ/1350/.

Duff, J.H., Tesoriero, A.J., Richardson, W.B., Strauss, E.A., and Munn, M.D., 2008, Whole-stream response to nitrate loading in three streams draining agricultural landscapes: Journal of Environmental Quality, v. 37, no. 3, p. 1,133-1,144, DOI: 10.2134/jeq2007.0187.

Dunkle, S.A., Plummer, L.N., Busenberg, E., Phillips, P.J., Denver, J.M., Hamilton, P.A., Michel, R.L., and Coplen, T.B., 1993, Chlorofluorocarbons $\left(\mathrm{CCl}_{3} \mathrm{~F}\right.$ and $\left.\mathrm{CCl}_{2} \mathrm{~F}_{2}\right)$ as dating tools and hydrologic tracers in shallow groundwater of the Delmarva Peninsula, Atlantic Coastal Plain, United States: Water Resources Research, v. 29, no. 12, p. 3,837-3,860, DOI: 10.1029/93wr02073.

Fenneman, N.M., and Johnson, D.W., 1946, Physical divisions of the United States: U.S. Geological Survey Map, 1 sheet, scale $1: 7,000,000$.

Ferrari, M.J., 2001, Occurrence and distribution of selected contaminants in public drinking-water supplies in the surficial aquifer in Delaware: U.S. Geological Survey Open-File Report 2001-327, 62 p., accessed April 1, 2002, at http:// pubs.usgs.gov/of/2001/ofr01-327/.
Fisher, T.R., Hagy, J.D., III, Boynton, W.R., and Williams, M.R., 2006, Cultural eutrophication in the Choptank and Patuxent estuaries of Chesapeake Bay: Limnology and Oceanography, v. 51, no. 1 II, p. 435-447.

Gallagher, D.L., Dietrich, A.M., Reay, W.G., Hayes, M.C., and Simmons, G.M., Jr., 1996, Ground water discharge of agricultural pesticides and nutrients to estuarine surface water: Ground Water Monitoring and Remediation, v. 16, no. 1, p. $118-129$.

Gesch, D.B., Evans, G.A., Mauck, J., Hutchinson, J., and Carswell, W.J., Jr., 2009, The National Map_Elevation: U.S. Geological Survey Fact Sheet 2009-3053, 4 p., accessed July 24, 2014, at http://pubs.usgs.gov/ $f_{s} / 2009 / 3053 /$.

Greene, E.A., LaMotte, A.E., and Cullinan, K.-A., 2005, Ground-water vulnerability to nitrate contamination at multiple thresholds in the Mid-Atlantic region using spatial probability models: U.S. Geological Survey Scientific Investigations Report 2004-5118, 32 p., accessed April 5, 2005, at http://pubs.water.usgs.gov/sir20045118/.

Hamilton, P.A., Denver, J.M., Phillips, P.J., and Shedlock, R.J., 1993, Water-quality assessment of the Delmarva Peninsula, Delaware, Maryland, and Virginia - effects of agricultural activities on, and distribution of, nitrate and other inorganic constituents in the surficial aquifer: U.S. Geological Survey Open-File Report 93-40, 95 p., accessed July 24, 2014, at http://pubs.usgs.gov/of/1993/0040/report.pdf.

Hancock, T.C., and Brayton, M.J., 2006, Environmental setting of the Morgan Creek Basin, Maryland, 2002-04: U.S. Geological Survey Open-File Report 2006-1151, 28 p., accessed January 20, 2007, at http://pubs.usgs.gov/ of $/ 2006 / 1151 /$.

Heckrath, G., Brookes, P.C., Poulton, P.R., and Goulding, K.W.T., 1995, Phosphorus leaching from soils containing different phosphorus concentrations in the Broadbalk experiment: Journal of Environmental Quality, v. 24, no. 5, p. 904-910.

Hirsch, R.M., Moyer, D.L., and Archfield, S.A., 2010, Weighted regressions on time, discharge, and season (WRTDS), with an application to Chesapeake Bay river inputs: Journal of the American Water Resources Association, v. 46, no. 5, p. 857-880, DOI: $10.1111 / \mathrm{j} .1752-1688.2010 .00482 . x$.

Hively, W.D., Lang, M., McCarty, G.W., Keppler, J., Sadeghi, A., and McConnell, L.L., 2009, Using satellite remote sensing to estimate winter cover crop nutrient uptake efficiency: Journal of Soil and Water Conservation, v. 64, no. 5, p. 303-313, DOI: 10.2489/jswc.64.5.303. 
Howarth, R., Billen, G., Swaney, D., Townsend, A., Jaworski, N., Lajtha, K., Downing, J., Elmgren, R., Caraco, N., Jordan, T., Berendse, F., Freney, J., Kudeyarov, V., Murdoch, P., and Zhao-Liang, Z., 1996, Regional nitrogen budgets and riverine $\mathrm{N} \& \mathrm{P}$ fluxes for the drainages to the North Atlantic Ocean: Natural and human influences: Biogeochemistry, v. 35, no. 1, p. 75-139, DOI: 10.1007/ bf02179825, accessed August 31, 2011, at http://dx.doi. org/10.1007/BF02179825.

Hussain, N., Church, T.M., and Kim, G., 1999, Use of 222Rn and 226Ra to trace groundwater discharge into the Chesapeake Bay: Marine Chemistry, v. 65, nos. 1-2, p. 127-134, DOI: 10.1016/s0304-4203(99)00015-8.

Jarvie, H.P., Sharpley, A.N., Spears, B., Buda, A.R., May, L., and Kleinman, P.J.A., 2013, Water quality remediation faces unprecedented challenges from "legacy phosphorus": Environmental Science and Technology, v. 47, p. 8,997-8,998, DOI: dx.doi.org/10.1021/es403160a.

Jordan, T.E., Andrews, M.P., Szuch, R.P., Whigham, D.F., Weller, D.E., and Jacobs, A.D., 2007, Comparing functional assessments of wetlands to measurements of soil characteristics and nitrogen processing: Wetlands, v. 27, no. 3, p. 479-497, DOI: 10.1672/0277-5212(2007)27[479:cfaowt] 2.0.co;2.

Karlsen, A.W., Cronin, T.M., Ishmans, S.E., Willard, D.A., Kerhin, R., Holmes, C.W., and Marot, M., 2000, Historical trends in Chesapeake Bay dissolved oxygen based on benthic foraminifera from sediment cores: Estuaries, v. 23, no. 4 , p. $488-508$.

Kemp, W.M., Boynton, W.R., Adolf, J.E., Boesch, D.F., Boicourt, W.C., Brush, G., Cornwell, J.C., Fisher, T.R., Glibert, P.M., Hagy, J.D., Harding, L.W., Houde, E.D., Kimmel, D.G., Miller, W.D., Newell, R.I.E., Roman, M.R., Smith, E.M., and Stevenson, J.C., 2005, Eutrophication of Chesapeake Bay: Historical trends and ecological interactions: Marine Ecology Progress Series, v. 303, p. 1-29.

Kleinman, P., Blunk, K.S., Bryant, R., Saporito, L., Beegle, D., Czymmek, K., Ketterings, Q., Sims, T., Shortle, J., McGrath, J., Coale, F., Dubin, M., Dostie, D., Maguire, R., Meinen, R., Allen, A., O’Neill, K., Garber, L., Davis, M., Clark, B., Sellner, K., and Smith, M., 2012, Managing manure for sustainable livestock production in the Chesapeake Bay watershed: Journal of Soil and Water Conservation, v. 67, no. 2, p. 54A-61A, DOI: 10.2489/ jswc.67.2.54A.

Knee, K.L., and Jordan, T.E., 2013, Spatial distribution of dissolved radon in the Choptank River and its tributaries: Implications for groundwater discharge and nitrate inputs: Estuaries and Coasts, v. 36, no. 6, p. 1,237-1,252, DOI: $10.1007 / \mathrm{s} 12237-013-9619-y$.
Knobel, L.L., Chapelle, F.H., and Meisler, H., 1998, Geochemistry of the northern Atlantic Coastal Plain aquifer system: U.S. Geological Survey Professional Paper 1404-L, 57 p., accessed July 24, 2014, at http://pubs.usgs.gov/ pp/1404l/report.pdf.

Krantz, D.E., Manheim, F.T., Bratton, J.F., and Phelan, D.J., 2004, Hydrogeologic setting and ground water flow beneath a section of Indian River Bay, Delaware: Ground Water, v. 42, no. 7, p. 1,035-1,051, DOI: 10.1111/j.1745-6584.2004. tb02642.x.

LaMotte, A.E., 2008a, National land cover database 2001 (NLCD01) Tile 2 northeast United States: NCLD01-2: U.S. Geological Survey Digital Data Series DS-383B, accessed July 24, 2014, at http://water.usgs.gov/GIS/metadata/ usgswrd/XML/nlcd01_2.xml.

LaMotte, A.E., 2008b, National land cover database 2001 (NLCD01) Tile 4 southeast United States: NLCD01_4: U.S. Geological Survey Digital Data Series DS-383D, accessed July 24, 2014, at http://water.usgs.gov/GIS/metadata/ usgswrd/XML/nlcd01_4.xml.

Langland, M.J., Blomquist, J.D., Moyer, D.L., Hyer, K.E., and Chanat, J.G., 2013, Total nutrient and sediment loads, trends, yields, and nontidal water-quality indicators for selected nontidal stations, Chesapeake Bay watershed, 1985-2011: U.S. Geological Survey Open-File Report 2013-1052, 60 p., accessed July 24, 2014, at http://pubs. usgs.gov/of/2013/1052/pdf/OFR2013-1052.pdf.

Langland, M.J., and Cronin, T., 2003, A summary report of sediment processes in Chesapeake Bay and watershed: U.S. Geological Survey Water-Resources Investigations Report 03-4123, 109 p., accessed July 24, 2014, at http://pa.water. usgs.gov/reports/wrir03-4123.pdf.

Langland, M.J., Raffensperger, J.P., Moyer, D.L., Landwehr, J.M., and Schwarz, G.E., 2006, Changes in streamflow and water quality in selected nontidal basins in the Chesapeake Bay watershed, 1985-2004: U.S. Geological Survey Scientific Investigations Report 2006-5178, 75 p., accessed July 24, 2014, at http://pubs.usgs.gov/sir/2006/5178/.

Leytem, A.B., and Sims, J.T., 2005, Changes in soil test phosphorus from broiler litter additions: Communications in Soil Science and Plant Analysis, v. 36, no. 17-18, p. 2,541-2,559, DOI: 10.1080/00103620500257143.

Leytem, A.B., Sims, J.T., and Coale, F.J., 2003, On-farm evaluation of a phosphorus site index for Delaware: Journal of Soil and Water Conservation, v. 58, no. 2, p. 89-97. 
Lindsey, B.D., Phillips, S.W., Donnelly, C.A., Speiran, G.K., Plummer, L.N., Böhlke, J.K., Focazio, M.J., Burton, W.C., and Busenberg, Eurybiades, 2003, Residence times and nitrate transport in ground water discharging to streams in the Chesapeake Bay watershed: U.S. Geological Survey Water-Resources Investigations Report 2003-4035, 201 p., accessed July 24, 2014, at http://pa.water.usgs.gov/reports/ wrir03-4035.pdf.

Linker, L.C., Batiuk, R.A., Shenk, G.W., and Cerco, C.F., 2013, Development of the Chesapeake Bay watershed Total Maximum Daily Load allocation: JAWRA, Journal of the American Water Resources Association, v. 49, no. 5, p. 986-1,006, DOI: 10.1111/jawr.12105, http://dx.doi. org/10.1111/jawr.12105.

Lowrance, R., Altier, L.S., Newbold, J.D., Schnabel, R.R., Groffman, P.M., Denver, J.M., Correll, D.L., Gilliam, J.W., Robinson, J.L., Brinsfield, R.B., Staver, K.W., Lucas, W., and Todd, A.H., 1997, Water quality functions of riparian forest buffers in Chesapeake bay watersheds: Environmental Management, v. 21, no. 5, p. 687-712, DOI: $10.1007 / \mathrm{s} 002679900060$.

Maguire, R.O., and Sims, J.T., 2002, Measuring agronomic and environmental soil phosphorus saturation and predicting phosphorus leaching with Mehlich 3: Soil Science Society of America Journal, v. 66, no. 6, p. 2,033-2,039.

Maizel, M.S., Muehlbach, G., Baynham, P., Zoerkler, J., Monds, D., Livari, T., Welle, P., Robbin, J., and Wiles, J., 1997, The potential for nutrient loadings from septic systems to ground and surface water resources and the Chesapeake Bay: U.S. Environmental Protection Agency EPA 903-R-97-006, Report CBP/TRS 166/97, 285 p., accessed November 8, 2012, at http://nepis.epa.gov/Exel ZyPURL.cgi? Dockey $=$ P1001 WW6.txt.

Manheim, F.T., Krantz, D.E., and Bratton, J.F., 2004, Studying ground water under Delmarva coastal bays using electrical resistivity: Ground Water, v. 42, no. 7, p. 1,052-1,068, DOI: 10.1111/j.1745-6584.2004.tb02643.x.

McCarthy, K., and Capel, P.D., 2009, A whole-system approach to understanding chemicals in the environment: U.S. Geological Survey Fact Sheet 2009-3042, accessed July 24, 2014, at http://pubs.usgs.gov/fs/2009/3042/.

McCarty, G.W., McConnell, L.L., Hapeman, C.J., Sadeghi, A., Graff, C., Hively, W.D., Lang, M.W., Fisher, T.R., Jordan, T., Rice, C.P., Codling, E.E., Whitall, D., Lynn, A., Keppler, J., and Fogel, M.L., 2008, Water quality and conservation practice effects in the Choptank River watershed: Journal of Soil and Water Conservation, v. 63, no. 6, p. 461-474, DOI: $10.2489 /$ jswc.63.6.461.
McCarty, G.W., Mookherji, S., and Angier, J.T., 2007, Characterization of denitrification activity in zones of groundwater exfiltration within a riparian wetland ecosystem: Biology and Fertility of Soils, v. 43, no. 6, p. 691-698, DOI: $10.1007 / \mathrm{s} 00374-006-0151-0$.

McCollum, R.E., 1991, Buildup and decline in soil phosphorus: 30-Year trends on a typic umprabuult: Agronomy, v. 83, p. 77-85, DOI: 10.2134/agronj1991.000219620083000100 19x, accessed July 24, 2014, at https://www.agronomy.org/ publications/aj/abstracts/83/1/AJ0830010077.

McCoy, J., Sigrist, M., and Jaber, J., 2010, Upper Pocomoke agricultural best management practice evaluation project, 2010 Trust Fund Water Quality Monitoring Strategy, Maryland Department of Natural Resources, p. 13-16, accessed September 17, 2014, at http://www.dnr.maryland. gov/ccs/funding/pdfs/Monitoring_Strategy.pdf.

McCoy, J., Spotts, I., Jaber, J., and Trice, M., 2010, Corsica River restoration project, 2010 Trust Fund Water Quality Monitoring Strategy, Maryland Department of Natural Resources, p. 17-21, accessed September 17, 2014, at http://www.dnr.maryland.gov/ccs/funding/pdfs/Monitoring_ Strategy.pdf.

Meals, D.W., Dressing, S.A., and Davenport, T.E., 2010, Lag time in water quality response to best management practices: A review: Journal of Environmental Quality, v. 39, no. 1, p. 85-96, DOI: 10.2134/jeq2009.0108.

Meng, A.A., III, and Harsh, J.F., 1988, Hydrogeologic framework of the Virginia Coastal Plain: U.S. Geological Survey Professional Paper 1404-C, 82 p., accessed July 24, 2014, at http://pubs.water.usgs.gov/pp1404-C/.

Mid-Atlantic Water Program, 2012, Nutrient budgets for the Mid-Atlantic States, accessed July 16, 2012, at http://www. mawaterquality.agecon.vt.edu/.

Mixon, R.B., Berquist, C.R., Jr., Newell, W.L., Johnson, G.H., Powars, D.S., Schindler, J.S., and Rader, E.K., 1989 , Geological map and generalized cross sections of the Coastal Plain and adjacent parts of the Piedmont, Virginia: U.S. Geological Survey Miscellaneous Investigations Map I-2033, 2 p., accessed July 24, 2014, at http://pubs.er.usgs. gov/publication/i2033.

Moyer, D.L., Hirsch, R.M., and Hyer, K.E., 2012, Comparison of two regression-based approaches for determining nutrient and sediment fluxes and trends in the Chesapeake Bay watershed: U.S. Geological Survey Scientific Investigations Report 2012-5244, 118 p., accessed January 14, 2013, at http://pubs.er.usgs.gov/publication/sir20125244. 
Phillips, S.W., and Donnelly, C.A., 2003, Upper Pocomoke watershed, in Lindsey, B.D., Phillips, S.W., Donnelly, C.A., Speiran, G.K., Plummer, L.N., Böhlke, J.K., Focazio, M.J., Burton, W.C., and Busenberg, E., eds., Residence times and nitrate transport in ground water discharging to streams in the Chsapeake Bay watershed: U.S. Geological Survey Water-Resources Investigations Report 03-4035.

Prasad, M.B.K., Sapiano, M.R.P., Anderson, C.R., Long, W., and Murtugudde, R., 2010, Long-term variability of nutrients and chlorophyll in the Chesapeake Bay: A retrospective analysis, 1985-2008: Estuaries and Coasts, v. 33, no. 5, p. 1,128-1,143, DOI: $10.1007 / \mathrm{s} 12237-010-9325-\mathrm{y}$.

Puckett, L.J., 2004, Hydrogeologic controls on the transport and fate of nitrate in ground water beneath riparian buffer zones: Results from thirteen studies across the United States: Water Science and Technology, v. 49, no. 3, p. $47-53$.

Puckett, L.J., Zamora, C., Essaid, H., Wilson, J.T., Johnson, H.M., Brayton, M.J., and Vogel, J.R., 2008, Transport and fate of nitrate at the ground-water/surface-water interface: Journal of Environmental Quality, v. 37, no. 3, p. 1,0341,050, DOI: $10.2134 /$ jeq2006.0550.

Reay, W.G., Gallagher, D.L., and Simmons G.M, Jr., 1992, Groundwater discharge and its impact on surface water quality in a Chesapeake Bay inlet: Water Resources Bulletin, v. 28, no. 6, p. 1,121-1,134.

Ritter, W.F., Scarborough, R.W., and Chirnside, A.E.M., 1998, Winter cover crops as a best management practice for reducing nitrogen leaching: Journal of Contaminant Hydrology, v. 34, nos. 1-2, p. 1-15, DOI: 10.1016/ s0169-7722(98)00087-4.

Robinson, M.A., and Reay, W.G., 2002, Ground water flow analysis of a Mid-Atlantic outer Coastal Plain watershed, Virginia, U.S.A: Ground Water, v. 40, no. 2, p. 123-131.

Sadeghi, A., McCarty, G., Hively, D., Moriasi, D., and Shirmohammadi, A., 2008, Watershed model evaluation of agricultural ditch drainage control structures for improved water quality, in Proceedings of Conference on 21st Century Watershed Technology: Improving Water Quality and Environment 2008, March 29 through April 3, 2008, Concepción, Chile, p. 424-434.

Sanford, W.E., and Pope, J.P., 2007, A simulation of groundwater discharge and nitrate delivery to Chesapeake Bay from the lowermost Delmarva Peninsula, USA, Perugia, International Symposium: A New Focus on GroundwaterSeawater Interactions - 24th General Assembly of the International Union of Geodesy and Geophysics (IUGG), p. 326-333.
Sanford, W.E., and Pope, J.P., 2013, Quantifying groundwater's role in delaying improvements to Chesapeake Bay water quality: Environmental Science \& Technology, v. 47, no. 23, DOI: 10.1021/es401334k.

Sanford, W.E., Pope, J.P., Selnick, D.L., and Stumvoll, R.F., 2012, Simulation of groundwater flow in the shallow aquifer system of the Delmarva Peninsula, Maryland and Delaware: U.S. Geological Survey Open-File Report 2012-1140, 58 p., accessed December 7, 2012, at http:// pubs.er.usgs.gov/publication/ofr20121140.

Sharpley, A.N., Kleinman, P.J.A., McDowell, R.W., Gitau, M., and Bryant, R.B., 2002, Modeling phosphorus transport in agricultural watersheds: Processes and possibilities: Journal of Soil and Water Conservation, v. 57, no. 6, p. 425-439.

Shedlock, R.J., Bolton, D.W., Cleaves, E.T., Gerhart, J.M., and Nardi, M.R., 2007, A science plan for a comprehensive regional assessment of the Atlantic Coastal Plain Aquifer System in Maryland: U.S. Geological Survey Open-File Report 2007-1205, 27 p., accessed January 5, 2008, at http://pubs.usgs.gov/of/2007/1205/.

Shedlock, R.J., Denver, J.M., Hayes, M.A., Hamilton, P.A., Koterba, M.T., Bachman, L.J., Phillips, P.J., and Banks, W.S.L., 1999, Water-quality assessment of the Delmarva Peninsula, Delaware, Maryland, and Virginia: Results of investigations, 1987-91: U.S. Geological Survey WaterSupply Paper 2355-A, 41 p., accessed October 22, 2013, at http://pubs.usgs.gov/wsp/2355a/report.pdf.

Shenk, G.W., and Linker, L.C., 2013, Development and application of the 2010 Chesapeake Bay watershed total maximum daily load model: JAWRA, Journal of the American Water Resources Association, v. 49, no. 5, p. 1,042-1,056, DOI: 10.1111/jawr.12109, http://dx.doi.org/10.1111/ jawr.12109.

Shigaki, F., Schmidt, J.P., Kleinman, P.J.A., Sharpley, A.N., and Allen, A.L., 2009, Nitrogen fate in drainage ditches of the coastal plain after dredging: Journal of Environmental Quality, v. 38, no. 6, p. 2,449-2,457, DOI: 10.2134/ jeq2008.0268.

Speiran, G.K., 1996, Geohydrology and geochemistry near coastal ground-water-discharge areas of the Eastern Shore, Virginia: U.S. Geological Survey Water-Supply Paper 2479, 73 p., accessed April 19, 2012, at http://pubs.er.usgs.gov/ publication/wsp 2479 .

Sprague, L.A., Langland, M.J., Yochum, S.E., Edwards, R.E., Blomquist, J.D., Phillips, S.W., Shenk, G.W., and Preston, S.D., 2000, Factors affecting nutrient trends in major rivers of the Chesapeake Bay Watershed: U.S. Geological Survey Water-Resources Investigations Report 2000-4218, 109 p., accessed July 24, 2014, at http://pubs.water.usgs.gov/ wri004218. 
Staver, K.W., 2010, The effect of agricultural best management practices on subsurface nitrogen transport in the German Branch watershed, 2010 Trust Fund Water Quality Monitoring Strategy, Maryland Department of Natural Resources, p. 26-28, http://www.dnr.maryland.gov/ccs/ funding/pdfs/Monitoring_Strategy.pdf.

Staver, K.W., and Brinsfield, R.B., 1995, Assessing the impact of changes in management practices on nutrient transport from Coastal Plain agricultural systems: Chesapeake Research Consortium Final Report CRC Project CA NPS\#3, $82 \mathrm{p}$.

Staver, K.W., and Brinsfield, R.B., 1996, Seepage of groundwater nitrate from a riparian agroecosystem into the Wye River estuary: Estuaries, v. 19, no. 2B, p. 359-370.

Staver, K.W., and Brinsfield, R.B., 1998, Using cereal grain winter cover crops to reduce groundwater nitrate contamination in the Mid-Atlantic Coastal Plain: Journal of Soil and Water Conservation, v. 53, no. 3, p. 230-240.

Staver, K.W., and Brinsfield, R.B., 2001, Agriculture and water quality on the Maryland Eastern Shore: Where do we go from here?: BioScience, v. 51, no. 10, p. 859-868.

Staver, K.W., and Brinsfield, R.B., 2010a, Assessing the impact of changes in management practices on nutrient transport from coastal plain agricultural systems, 2010 Trust Fund Water Quality Monitoring Strategy, Maryland Department of Natural Resources, p. 7-9, accessed September 17, 2014, at http://www.dnr.maryland.gov/ccs/ funding/pdfs/Monitoring_Strategy.pdf.

Staver, K.W., and Brinsfield, R.B., 2010b, Evaluating changes in subsurface nitrogen discharge from an agricultural watershed into Chesapeake Bay after implementation of a groundwater protection strategy, 2010 Trust Fund Water Quality Monitoring Strategy, Maryland Department of Natural Resources, p. 10-12, accessed September 17, 2014, at http://www.dnr.maryland.gov/ccs/funding/pdfs/ Monitoring_Strategy.pdf.

Sutton, A.J., Fisher, T.R., and Gustafson, A.B., 2010, Effects of restored stream buffers on water quality in non-tidal streams in the Choptank River basin: Water, Air, and Soil Pollution, v. 208, no. 1-4, p. 101-118, DOI: 10.1007/ s11270-009-0152-3.

Tesoriero, A.J., Spruill, T.B., and Eimers, J.L., 2004, Geochemistry of shallow ground water in coastal plain environments in the southeastern United States: Implications for aquifer susceptibility: Applied Geochemistry, v. 19, no. 9, p. 1,471-1,482, DOI: 10.1016/j.apgeochem.2004.01.021.

U.S. Department of Agriculture, 2009, 2007 Census of agriculture, accessed March 21, 2012, at http://www.agcensus. usda.gov/Publications/2007/index.php.
U.S. Department of Agriculture, 2014, 2012 Census of agriculture quick stats, accessed June 16, 2014, at http://quickstats. nass.usda.gov/?source_desc $=$ CENSUS.

U.S. Environmental Protection Agency, 2000, Ambient water quality criteria recommendations-Information supporting the development of State and Tribal nutrient criteria-Rivers and streams in Nutrient Ecoregion XIV: U.S. Environmental Protection Agency Report EPA 822B-00-022, 84 p., accessed April 20, 2012, at http://water. epa.gov/scitech/swguidance/standards/criteria/nutrients/ upload/2007_09_27_criteria_nutrient_ecoregions_rivers_ rivers_14.pdf.

U.S. Environmental Protection Agency, 2004, 2004 Edition of the drinking-water standards and health advisories: U.S. Environmental Protection Agency Report 822-R-04-005, 20 p., accessed July 24, 2014, at http://water.epa.gov/action/ advisories/drinking/upload/2009_04_27_criteria_drinking_ dwstandards2004.pdf.

U.S. Environmental Protection Agency, 2008a, Chesapeake Bay health and restoration assessment - A report to the citizens of the bay region: U.S. Environmental Protection Agency Publication 903-R-08-002, 33 p., accessed July 24, 2014, at http://www.chesapeakebay.net/documents/ cbp_26038.pdf.

U.S. Environmental Protection Agency, 2008b, National Coastal Condition Report III: U.S. Environmental Protection Agency Report EPA/842-R-08-002, 329 p., accessed May 26, 2011, at http://water.epa.gov/type/oceb/ assessmonitor/upload/nccr3_entire.pdf.

U.S. Environmental Protection Agency, 2009, Bay program nutrient point source database, U.S. Environmental Protection Agency, accessed June 24, 2009, at http://www.chesapeakebay.net/data/downloads/ bay_program_nutrient_point_source_database.

U.S. Environmental Protection Agency, 2011a, Bay barometer-A health and restoration assessment of the Chesapeake Bay and watershed in 2010: U.S. Environmental Protection

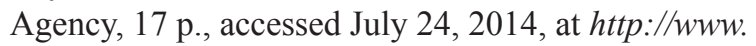
chesapeakebay.net/documents/cbp_59306.pdf.

U.S. Environmental Protection Agency, 2011b, Clean water act section 303(d)-Preliminary notice of total maximum daily load (TMDL) development for the Chesapeake Bay: Federal Register, v. 76, no. 3, p. 549-550, accessed October 1, 2014, at https://www.federalregister.gov/ articles/2009/09/17/E9-22410/clean-water-act-section303d-preliminary-notice-of-total-maximum-daily-load-tmdldevelopment-for-the.

U.S. Geological Survey, 2014, USGS water data for the Nation, accessed January 29, 2014, at http://waterdata.usgs. gov/nwis. 
Vitousek, P.M., Aber, J.D., Howarth, R.W., Likens, G.E., Matson, P.A., Schindler, D.W., Schlesinger, W.H., and Tilman, D.G., 1997, Human alteration of the global nitrogen cycle: Sources and consequences: Ecological Applications, v. 7 , no. 3 , p. $737-750$.

Vroblesky, D.A., and Fleck, W.B., 1991, Hydrogeologic framework of the Coastal Plain of Maryland, Delaware, and the District of Columbia: U.S. Geological Survey Professional Paper 1404-E, 45 p., accessed July 24, 2014, at http://pubs.er.usgs.gov/publication/pp1404E.

Whitall, D., Hively, W.D., Leight, A.K., Hapeman, C.J., McConnell, L.L., Fisher, T., Rice, C.P., Codling, E., McCarty, G.W., Sadeghi, A.M., Gustafson, A., and Bialek, K., 2010, Pollutant fate and spatio-temporal variability in the Choptank River estuary: Factors influencing water quality: Science of the Total Environment, v. 408, no. 9, p. 2,096-2,108, DOI: 10.1016/j.scitotenv.2010.01.006.

Wieczorek, M.E., and LaMotte, A.E., 2010a, Attributes for NHDPlus catchments (version 1.1) for the conterminous United States: NLCD 2001 land use and land cover: U.S. Geological Survey Digital Data Series DS-490-15, accessed July 24, 2014, at http://pubs.er.usgs.gov/publication/ dds49015.

Wieczorek, M.E., and LaMotte, A.E., 2010b, Attributes for NHDPlus catchments (version 1.1) for the conterminous United States: Nutrient application (phosphorus and nitrogen) for fertilizer and manure applied to crops (cropsplit), 2002: U.S. Geological Survey Digital Data Series DS-49008, accessed July 24, 2014, at http://pubs.er.usgs.gov/ publication/dds 49008 .

Wieczorek, M.E., and LaMotte, A.E., 2010c, Attributes for NHDPlus catchments (version 1.1) for the conterminous United States: Nutrient inputs from fertilizer and manure, nitrogen and phosphorus, 2002: U.S. Geological Survey Digital Data Series DS-490-17, accessed July 24, 2014, at http://pubs.er.usgs.gov/publication/dds 49017.

Wieczorek, M.E., and LaMotte, A.E., 2010d, Attributes for NHDPlus catchments (version 1.1) for the conterminous United States: Average atmospheric (wet) deposition of inorganic nitrogen, 2002: U.S. Geological Survey Digital Data Series DS-490-02, accessed July 24, 2014, at http:// pubs.er.usgs.gov/publication/dds49002.

Wolock, D.M., 1997, STATSGO soil characteristics for the conterminous United States: U.S. Geological Survey OpenFile Report 97-656, accessed July 24, 2014, at http://water. usgs.gov/GIS/metadata/usgswrd/XML/muid.xml. 
Prepared by USGS West Trenton Publishing Service Center. Edited by Valerie M. Gaine.

Graphics and layout by Timothy W. Auer.

For additional information, contact:

Director, MD-DE-DC Water Science Center

U.S. Geological Survey

5522 Research Park Drive

Baltimore, MD 21228

or visit our Web site at: http://md.water.usgs.gov 
焉

$\vec{j}$

$\sum_{\vdots}$

号 